University of Chicago Law School

Chicago Unbound

Journal Articles

Faculty Scholarship

1983

\title{
Shaping the Eighteenth-Century Criminal Trial: A View from the Ryder Sources
}

John H. Langbein

Follow this and additional works at: https://chicagounbound.uchicago.edu/journal_articles

Part of the Law Commons

\section{Recommended Citation}

John H. Langbein, "Shaping the Eighteenth-Century Criminal Trial: A View from the Ryder Sources, " 50 University of Chicago Law Review 1 (1983).

This Article is brought to you for free and open access by the Faculty Scholarship at Chicago Unbound. It has been accepted for inclusion in Journal Articles by an authorized administrator of Chicago Unbound. For more information, please contact unbound@law.uchicago.edu. 


\title{
Shaping the Eighteenth-Century Criminal Trial: A View from the Ryder Sources
}

\author{
John H. Langbein†
}

$\dagger$ Max Pam Professor of American and Foreign Law, University of Chicago.

I wish to express my gratitude for the labors of the late K.L. Perrin, the transcriber of the Ryder shorthand sources, who died as I was completing this article. His transcripts made the sources accessible for scholarship. He arranged for the deposit of his personal carbon copies of the transcripts at the University of Chicago Law Library, and over the years from 1975 through 1981 he answered many questions. I deeply regret that I was unable to have the benefit of his advice on the text of this article. I also wish to acknowledge the kindness of the Earl of Harrowby in authorizing Mr. Perrin's deposit of the transcripts at Chicago.

John Beattie (Toronto) and John Styles (Bath) supplied references that greatly facilitated my work in the public records. Douglas Hay (Warwick), who first cited the Ryder assize diary in published scholarship, shared his notes with me. Malvin Zirker (Indiana) helped with the sources and literature for Henry Fielding. John Baker (Cambridge), James Cockburn (Maryland), Charles Gray (Chicago), Thomas Green (Michigan), R.H. Helmholz (Chicago), Joanna Innes (Oxford), Mark Kishlansky (Chicago), A.W.B. Simpson (Kent), and Geoffrey Stone (Chicago) commented on a prepublication draft. Judith Rose (J.D. Chicago 1982) helped locate the illustrations, and she constructed the calendar infra note 29 . A number of particular references are acknowledged in the footnotes.

Research of this sort is not cheap to conduct, especially from across the Atlantic; I am grateful to Dean Gerhard Casper and the University of Chicago Law School for the financial support that has made the work possible.

I wish to direct readers' attention to the three endnotes that appear at the conclusion of this article dealing with (1) the modernization and Americanization of spelling, punctuation, and so forth; (2) the conventions followed by the shorthand transcriber in preparing his transcripts; and (3) acknowledgements for the illustrations reproduced in the article. I am grateful to the editors of the Review for allowing deviations from their customary citation practices in order to facilitate the use of historical sources. 
Some of the most fundamental attributes of modern AngloAmerican criminal procedure for cases of serious crime emerged in England during the eighteenth century: the law of evidence, the adversary system, the privilege against self-incrimination, and the main ground rules for the relationship of judge and jury. ${ }^{1}$ In trying to understand the great developments of this period, legal historians have been bedeviled by source problems that to some extent must always remain insoluble. The present article is based primarily upon a pair of novel historical sources: the notebooks of Sir Dudley Ryder, who served as an Old Bailey trial judge in the 1750s; and a series of pamphlet accounts of Old Bailey trials that we verify by comparing them with the Ryder notes.

Our main theme is the influence of the pretrial process upon the development of the rules of trial. The Ryder-period sources give us a window on the institutions and procedures that were being employed to investigate crimes and to gather evidence for these trials. In some respects the ramshackle prosecutorial system of mid-century London worked remarkably well, but it had grievous shortcomings. The concern grew that the system encouraged false witnesses, who found it all too easy to bring about the condemnation of innocent men. We think that the relatively sudden rise of the law of evidence and of adversary trial procedure was, at least in part, a response.

Part I of this article is devoted to the description and comparison of the main sources. Discrepancies between the judge's notes and the pamphlets are identified and analyzed in the light of the different purposes for which the two sources were produced. Part II examines what the sources tell us about the composition of the bench and the allocation of functions within the nominally collegial trial judiciary of the Old Bailey. Part III looks at the offenses charged and the outcomes in the cases in our sample. Part IV is devoted to the pretrial procedure of detection and binding over for prosecution, with particular attention to the work of Henry Fielding, the novelist, and his brother John as principal magistrates for Middlesex in the period just before and during Dudley Ryder's tenure in judicial office. In Part V, we describe the crown witness system, upon which the Middlesex magistracy placed great reli-

I have discussed these points in Langbein, The Criminal Trial before the Lawyers, 45 U. CHI. L. REv. 263 (1978) [hereafter cited as Article I]. On the adversary system and the appearance of lawyers, see id. at 282-83, 307-16; on the law of evidence, see id. at 300-06; on the want of the privilege against self-incrimination, see $i d$. at 283-84; and on jury composition and jury control, see $i d$. at 272-300. 
ance, and its bearing on the rise of the law of evidence. In Part VI we discuss the reward system and the celebrated scandal that brought it into disrepute. Part VII is devoted to the trial caseloads and Part VIII to trial procedure and the advent of the adversary system.

\section{SOURCES}

Criminal law reporting in the modern sense is basically a nineteenth-century tradition, and one that reflects the radically altered state of affairs of the lawyer-dominated nineteenth-century trial. For most of the eighteenth century, when lawyers for prosecution and defense were rather peripheral figures, lawyers' literature was not much produced. ${ }^{2}$ Five years ago in an article in this journal, I undertook to identify and explain some of the procedural developments of the period from the mid-1670s to the mid-1730s. I based this work mainly on a little-known set of pamphlet sources that contain "probably the best accounts we shall ever have of what transpired in ordinary English criminal courts before the later eighteenth century." "These pamphlets, the Old Bailey Sessions Papers (hereafter OBSP), ${ }^{4}$ chronicle the trials that took place at the sittings ("sessions") of the Old Bailey. The. Old Bailey was the trial court for cases of serious crime (felony) committed in the city of London and the adjacent county of Middlesex. ${ }^{5}$ The court sat

- See Wigmore, A General Survey of the History of the Rules of Evidence, in 2 SBLBCT Essays in Anglo-Amrrican Legal History 691, 694-96 (Ass'n of Am. Law Schools ed. 1908).

3 Article I, supra note 1, at 271.

- The proper title as it appears during the Ryder period (with appropriate variations in dates, sessions, pamphlet numbers, and the names of mayors) is, for example, The Proceedings on the King's Commissions of the Peace, Oyer and Terminer, and Gaol Delivery for the City of London; and also the Gaol Delivery for the County of Middlesex, Held at Justice-Hall in the Old-Bailey, on Wednesday the 23rd, Thursday the 24th, Friday the 25th, Saturday the 26th, and Monday the 28th of October, in the 27th Year of His Majesty's Reign; Number VIII for the Year 1754: Being the Eighth Sessions in the Mayoralty of the Right Hon. Thomas Rawlinson, Esq., Lord-Mayor of the City of London (London 1754) [hereafter cited by month and year as OBSP]. For discussion of London mayoral years as dating conventions, see infra text accompanying note 28.

- A few other courts had nominal capital jurisdiction overlapping the Old Bailey's venue, but this was of no importance. The House of Lords could try peers, and King's Bench could (but virtually never did) try felons "at the bar." The High Court of Admiralty convened "Admiralty sessions" for felonies arising on the high seas and navigable waters. These cases were tried in London by London juries presided over by royal court judges proceeding in accordance with ordinary common law criminal procedure, so that the practice resembled a special sitting of the Old Bailey. During the Ryder years (1754-1756), Admiralty handled only a few criminal cases, all of them genuinely maritime and arising well away from London. See Public Record Office, London [hereafter cited as PRO] HCA (High 
eight times a year.

The OBSP report the outcomes of every trial held in each sessions, and they contain supposedly verbatim narratives for most of the trials. Although the OBSP can be immensely revealing, they have shortcomings that considerably impair their usefulness and reliability as a legal historical source. The OBSP were an early species of periodical journalism, purveying a diet of true-life crime stories for the interest and amusement of a nonlawyer readership. They were sold on the streets of London within days of the trials they reported. In the mid-1750s, the period that we shall be emphasizing in the present article, the price was four pence a pamphlet. The OBSP were not meant to serve as legal precedents, although we shall see that the legal system of the 1750s found a few uses for them. (Well after our period, however, the OBSP changed character and title. The series became a true law reporter that continued until World War I.)

Although the OBSP purport to present verbatim accounts of most of the trials held at each sessions, these narratives have suffered much deletion and compression. In the 1750s the publishers of the OBSP were producing two ${ }^{6}$ twenty-page pamphlets for each of the eight sessions. Since a typical sessions lasted three or four days, during which time the court might commonly conduct fifty felony trials, the forty pages of OBSP pamphlet text must have omitted " $[m]$ lost of what was said at an Old Bailey sessions . . . . Pamphlet reports of the size in question could not begin to capture the full proceedings." Perhaps the most unfortunate aspect of this process of deletion and compression is that it reflected what we might call the editorial policy of the publishers, which was to entertain lay readers. The OBSP "omit much procedural and doctrinal detail that would have interested lawyers; they emphasize the factual detail of witnesses' and defendants' tales, especially in sensational cases."8

If, as now seems likely, the history of the eighteenth-century criminal trial will have to be written quite largely from these suspect sources, it would be highly desirable to locate other accounts that might serve as a check on the reliability of the OBSP. The standard contemporary sources do not perform this corroborating

Court of Admiralty) 1/20, 1/58. Admiralty did not encroach upon the Old Bailey's exclusive venue of London and Middlesex offenses.

- Sometimes three. See, e.g., OBSP (Apr./May 1754), at 161.

7 Article I, supra note 1, at 271 (emphasis in original).

Id. at 270. 
function satisfactorily. The surviving official records-such as indictments, trial rosters, recognizances, depositions, and so forth-confirm the charges and the outcomes but do not narrate the trials. Those law reports and other legal writings that touch upon the conduct of criminal trials are scarce and unsystematic. ${ }^{9}$ The contemporary press contains relatively little in the way of trial reporting. ${ }^{10}$

Some years ago I began to explore the possibility that among the surviving exemplars of what are called "judges' notes," there might appear narrative trial reports of sufficient quality to supply this cross-check on the OBSP. The term "judges' notes" has been used somewhat loosely, ${ }^{11}$ but in the main it means the minutes written down in court by the presiding judge as he conducted the oral public trial. We shall have more to say below about why these notes were made. The primary purpose was to aid the judge's recollection at the trial when it came time for him to sum up the evidence and to instruct the jury, but the judge retained his notes lest he have need of them in certain post-verdict proceedings. Judges' notes were not official documents and did not, therefore, enter into the public records. Most of those known to have survived have come into the manuscript collections of the British Library, Harvard, and the inns of court, while others are scattered among a variety of libraries and in private hands. ${ }^{\mathbf{1 2}}$

- Regarding the main series, the State Trials, see Article I, supra note 1, at 264-67. The definitive edition, to which all subsequent citation in this article refers, is T.B. HowrL, Complete Collection of State Trials and Procendings for High Treason and Other Crimes and Misdrmenors prom the Earlizst Prriod (London 1809-1826) (33 vols.) [hereafter cited as ST. TR.].

10 The OBSP were protected from competition by license of the London authorities, discussed infra text accompanying notes 35-37. As for the assizes held in the counties, there is virtually no reporting in the provincial press, which in this period mostly reprinted from London sources rather than originating local copy. The main function of the provincial press was to join local advertising with international and national news at a time when it was still too costly for the London press to circulate widely in the provinces.

11 For example, the papers of Martin Wright, King's Bench judge from 1740 to 1754, reckoned in John Baker's compilation of judges' notes, see infra note 12, are predominantly litigation papers prepared by the parties or else manuscript law reports. See 1 Catalogus of Manuscaipts in the Library of the Honourable Society of the InNer Trmple 186-205 (J.C. Davies ed. 1972).

12 See the list supplied by Baker, The Dark Age of English Legal History, in Legal History Studirs 1972, at 1, 19-20, 26-27 (D. Jenkins ed. 1975). There is an extensive collection of judges' notes in the Harvard Law Library, described by John Baker as "the largest held by any Library," some definitely attributed to Thomas Denison, a King's Bench judge from 1742 to 1765. 1 J.H. Baker, English Lggat Manuscripts: Catalogug of the Manuscript Year Books, Readings, and Law Reports in the Library of the Harvard Lap ScHool 65, 65-75 (1975). Some years ago I reported a few instances of the use of judges' notes in Chancery's review of verdicts taken in aid of Chancery jurisdiction. Langbein, Fact 
Judges' notes originate so close to the events we are trying to discern that they never cease to tantalize. For the most part, however, they have been disappointing, and one would be hard pressed to point to any significant legal historical knowledge that has been wrested from them thus far. ${ }^{13}$ The difficulties that account for our inability to extract much useful information from these sources are nicely exemplified in the extensive notes that Lord Hardwicke left from his days as a trial judge in the 1730 s. ${ }^{14}$ Hardwicke's handwriting is difficult, in places undecipherable, and even when legible his entries are usually so curt and cryptic that the narrative of the trial cannot be reconstructed adequately from what he records. His notes magnify rather than correct for the compression that is the worrisome shortcoming of OBSP reports. Hardwicke took his notes in longhand, which drastically limited the amount of information he could record. The OBSP, by contrast, were based upon the notes of shorthand reporters. ${ }^{15}$ Hardwicke jotted down his notes in haste and did not revise or correct them, since their purpose was largely fulfilled within moments of their making when he summed u? the case and instructed the jury. He had no reason thereafter to edit his notes and to make them coherent, as the OBSP reporters did in order to produce marketable pamphlets. Small wonder, then, that judges' notes as a genre seem to add so little, especially when compared with the polished product of the OBSP.

In the 1970s there came to light one set of judges' notes vastly more detailed than any previously known for the eighteenth century. These are the notes of Sir Dudley Ryder, who was appointed Chief Justice of King's Bench in 1754 after a long career as Attorney General. Ryder died in office after only two years on the

Finding in the English Court of Chancery: A Rebuttal, 83 YALE L.J. 1620, 1626 n.34 (1974). Baker has suggested that changes in common law procedures for reviewing verdicts led to the making and retention of judges' notes, beginning around 1700. J.H. BAKER, AN INTRODuction to English Legal History 74 (2d ed. 1979); see also Baker, The Refinement of English Criminal Jurisprudence, 1500-1848, in CRIME aND CRIMINAL Justice IN EUROPE AND Canada 17, 31-32 (L. Knafla ed. 1981).

is It should also be said that until lately nobody has much tried. Professor James C. Oldham of Georgetown University Law Center is currently preparing a scholarly edition and introduction to Lord Mansfield's notes, which were discovered in Scone Palace in 1967 by Edmund Hewart, an English chancery master. See Hewart, Lord Mansfield's Note Books, 92 Law Q. Rev. 438 (1976); see also E. Hzwapt, LoRd Mansfield 49-57 (1979).

14 British Library [hereafter cited as BL] (formerly British Museum) Additional Manuscripts [hereafter abbreviated as MS] 36,028-36,044. See Cataloguz of Additions to the Manuscripts in the British Museum in the Years 1894-1899 (Part I: Descriptions), at 396 (British Museum 1901).

1s See infra text accompanying notes 30,47 . 

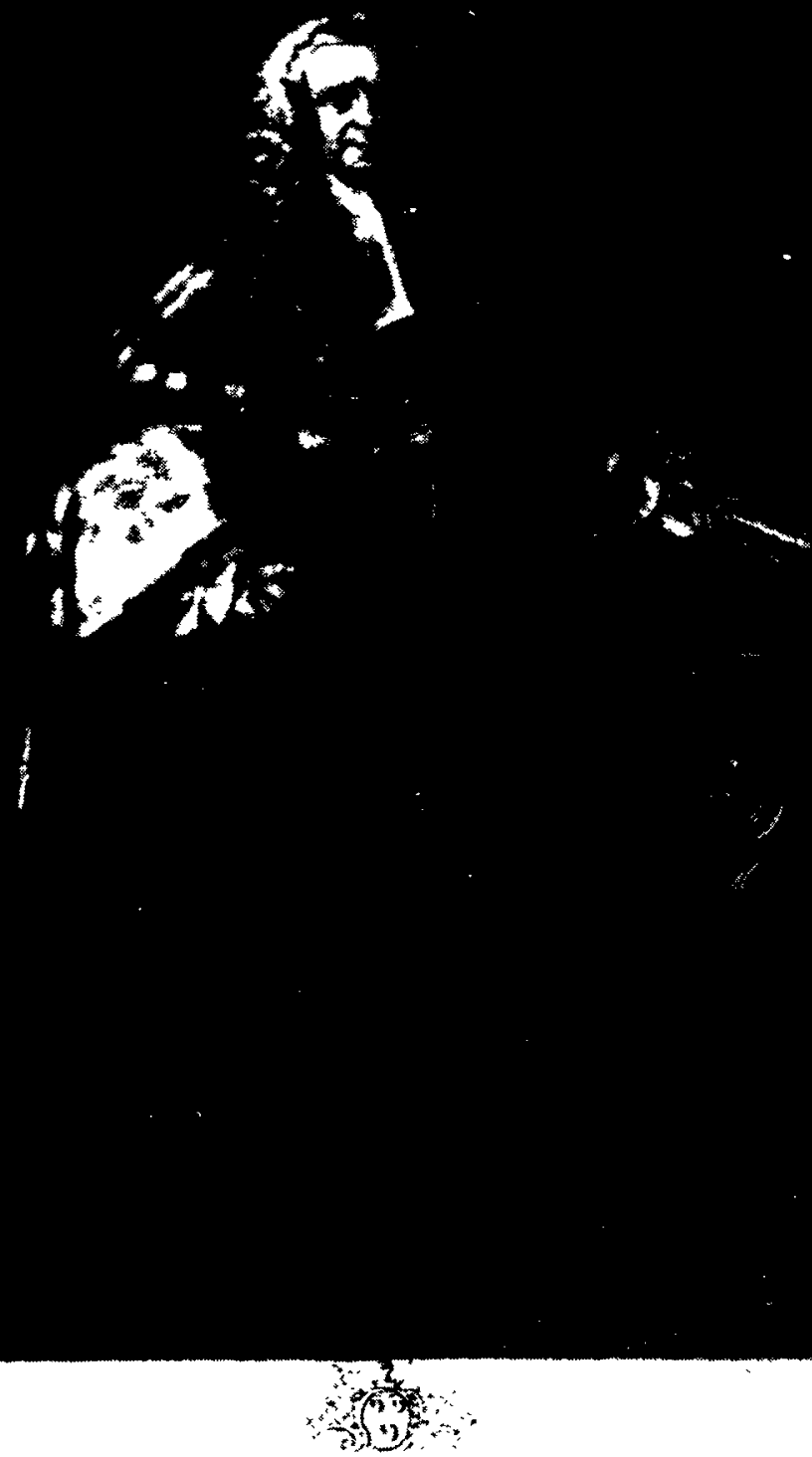

Sir Dudley Ryder, shown in judicial robes, hence from the period 1754-1756. 
bench. ${ }^{18} \mathrm{He}$ was succeeded by Lord Mansfield, whose long and celebrated career eclipses historical recollection of Ryder's brief tenure. But Ryder had a special skill that has made his judge's notes uniquely detailed and hence uniquely valuable. Ryder wrote shorthand. In his youth he had mastered one of the standard shorthand systems of the era, and he used it in his personal and professional records and diaries for decades before he acceded to the bench. ${ }^{17}$

The judges of the three royal central courts served as trial judges at the Old Bailey in a rotation; two or three of them joined the Recorder of London, the permanent judge of the Old Bailey, for each sessions. In the 1750s the Chief Justice of King's Bench took his turns in April and October. Ryder sat at four sessions, October of 1754, April and October of 1755, and April/May of 1756 (he died later that May). At these four sessions the Old Bailey conducted 171 felony trials. Ryder presided at about a quarter of them, forty-four trials, and his judge's notes survive for all fortyfour. The original notes are contained in a single notebook, the property of the Earls of Harrowby (the peerage that, with some difficulty, ${ }^{18}$ was founded on Ryder's career). The notebook, to-

18 For biography on Ryder see 17 Dictionary of National Biography 529-31 (19371938 ed.) (entry by G. Norgate) [hereafter cited as DNB]; E. Foss, Brographis JuRIDICA: A Biographical Dictionary of THE Judges of England 1066-1870, at 575 (1870) [hereafter cited as E. Foss, Blographia Juridica]; 8 E. Foss, The Judges of England 164-66 (London 1848-1864) (9 vols.); 2 J. CaMapbel, ThB Lives of the Chizf Justices of England 233-65 (Boston 1850) (1st ed. London 1849).

17 Ryder kept a shorthand diary during his days as a law student in London. A portion covering about a year and a half survives and was transcribed and published in part "as a social and historical document." The Diary of DudLey RYder 1715-1716, at viii (W. Matthews transcr. \& ed. 1939) [hereafter cited as RxDER STUdenr Diary]. A page of the shorthand script is reproduced in id. facing $p$. 64. The transcriber explains that the system of shorthand "is similar to Jeremiah Rich's, in which so many diaries of the eighteenth and late seventeenth centuries were written." Id. at vii.

This work is not to be confused with the document discussed infra text accompanying notes 21, 91-116, which we call Ryder's assize diary and which stems from the years 17541755, four decades later. Regarding the transcription of the Ryder judge's notes and assize diary, see infra Endnote 2.

18 Ryder died suddenly the night before he was to be elevated to the peerage, and his son had to wait 20 years for the peerage to be created. See 2 J. CAMPBELL, supra note 16, at 257-59.

A scandalous broadside, probably published shortly after Ryder's death, exulted in the failure of the peerage. It is done in the style of a mock epitaph and was doubtless meant to settle some political scores among the living:

Here rests at last, from all his sanguinary Desires, Sir Dudley Ryder, knight; whose Love of Money was only exceeded by his Lust of Punishment; formed by Nature for all the Chicanery of the Law, improved by the double and deceitful Education of a Presbyterian. By unwaried [sic] Application to his own Interest, by prostituting his Conscience, and a true Time-serving Spirit in spite of Genius, from the basest Original, he acquired the immense Sum of Three hundred thousand Pounds; and wriggled himself 
gether with other volumes of notes that Ryder made while conducting civil (nisi prius) cases, is now on deposit at Lincoln's Inn. ${ }^{19}$ Fortunately, all these shorthand judge's notes were transcribed in the 1970s and the typescript placed on deposit at Lincoln's Inn (and subsequently at the University of Chicago Law Library). ${ }^{20}$ The transcription is the work of K.L. Perrin, who rendered many other Ryder shorthand documents into typescript for the Harrowby muniments over a period of three decades until his death in 1981. The researcher who is prepared (as I have been) to rely upon the Perrin transcription does not need to master the shorthand.

Related to the judge's notes at Lincoln's Inn but not included with that deposit is another shorthand document, hereafter called the assize diary, which Perrin transcribed some years earlier for the Harrowby muniments. ${ }^{21}$ Ryder recorded in this diary some of

into the post of Attorney General. In the Execution of this Office, his Heart constantly felt Affliction, his Eye ever flowed with Sorrow when the Innocent escaped unpunished. Hence, by slavish Obedience to Ministerial Mandates In wresting Laws to arbitrary Purposes, he ascended the Seat of Lord Chief Justice. The same Thirst of Vengeance still waited on his Footsteps; those whom he longed to punish as Attorney [General], he now condemned with Delight as Judge; Truth found no Justice, Virtue no Favor, Innocence no Mercy when in Opposition to Court [i.e., government] Measures . . . . Enemy to Liberty, steady in his Country's Ruin, encouraged and adapted by all the Qualities in a Head and Heart which disgrace human Nature to request Nobility, he asked, and it was granted. Heaven and Monarchs behold, with different Eyes, him, whom his Sovereign summoned to a Peerage, God snatched to answer for his Crimes; for know, the Almighty will not always, unresenting, permit the Ambitious to receive, nor Kings to bestow those Honors on the Nefarious, which are only the just Reward of Virtue.

Anon., Epitaph for Sir Dudley Ryder, Knight (n.p., n.d. [1756?]) (BL shelfmark 102.d.3(2)).

10 The transcriber renders the shorthand documents as "Law notes of Sir Dudley Ryder," and he numbers them Documents 12-17. The volume I am using, the Old Bailey notes, is Document 14, which he transcribes in 62 pages of single-spaced typescript. I cite this typescript hereafter as Ryder Notebook. Regarding the work of the transcriber and the conventions he employed in dealing with the particular variety of shorthand Ryder used, see infra Endnote 2.

The manuscript notebooks are catalogued as Cases in [King's Bench] with Notes of the Judg[ments] Delivered by L.C.J. Ryder, in 2 J.H. BakgR, English Legal Manuscripts: Catalogug of the Manuscript Year Books, Readings and Law Reports in Lincoln's Inn, the Bodleian Library and Gray's InN 118 (1978).

${ }^{20}$ Shelfmark KA 29.R96A4.1973.

"2 A copy is now on deposit at the University of Chicago Law Library, shelfmark KA 29.R96A4.1973 (Supp. no. 1). The manuscript diary is transcribed as "Legal notebook of Sir Dudley Ryder, 1754/55," and numbered Document 19(f), Volume 1129 of the Harrowby Manuscripts, Sandon Hall. This typescript of 28 single-spaced pages is hereafter cited as Ryder Assize Diary. Douglas Hay first made use of the diary, citing a speech Ryder delivered in sentencing a woman to death. See Hay, Property, Authority and the Criminal Law, in Albion's Fatal Tree: Crime and Society in Eighteenth-Century England 17, 29 (D. Hay et al. eds. 1975) [collection hereafter cited as Albion's Fatal TrEe]. The speech is mentioned in this article, infra text accompanying note 477. For further discussion of the diary see infra text accompanying notes 91-116. 
his activity as a judge on the Home Circuit during the summer assizes in 1754 and 1755 . The diary has proved a valuable source of information on many aspects of assize and Old Bailey practice.

Ryder's Old Bailey notes have an importance that is quite out of proportion to the forty-four relatively mundane felony trials there evidenced. Because the notes cover cases that were being recorded independently for publication in the OBSP, they give us that cross-check on the reliability of the OBSP that has been so needed.

\section{A. The OBSP of the $1750 \mathrm{~s}$}

In the former article I had occasion to discuss the development of the OBSP from the inception of the genre in the 1670 s into the mid-1730s. ${ }^{22}$ By the mid-1750s, where the present study resumes, the OBSP had undergone some further refinements.

1. Numeration. By the 1750 s it had long become the practice to paginate consecutively the sixteen or more pamphlets produced for the eight sessions held each year. For the three years (17541756) encompassing Ryder's four sessions, each OBSP volume runs about 350 pages. ${ }^{23}$

The editors were now assigning identification numbers to each accused, which appear as the initial entry for each case report. The accused rather than the cases were numbered, hence cases that involve multiple accused have numbers for each. When the same accused was tried a second time at the same sessions (on another indictment) he was not assigned a new number. ${ }^{24}$ The numbering began anew each year; the last reckoned accused was number 514

22 Article I, supra note 1, at 267-72.

${ }^{23}$ For 1754, 344 pages; for 1755, 364 pages; for 1756, 352 pages.

24 For example, in the case of Charles Cane, discussed extensively infra text accompanying notes $328-53$, involving prosecutions for unrelated shopthefts in consecutive trials, the one offender number (200) is used for both. I shall employ the citation convention of disclosing these numbers prefixed by the number signal (\#) in a parenthetical that describes the month and date of the OBSP pamphlet, for example for Cane, OBSP (Apr./May 1756, \#200), at 167.

The OBSP contain a goodly number of typographical errors, perhaps not surprisingly in view of the pressure to bring the pamphlets to market hastily. Occasionally, one of the offender numbers is deleted or garbled. For example, in the case of Thomas Rolf, discussed infra text accompanying notes 60-64, the pamphlet prints the number as 502, whereas sequence indicates that it should have been 504 (502 having already been used). I treat the case as though the error had been corrected, and cite it OBSP (Oct. 1754, \#504), at 326.

An example of the other type of error, an omitted number, from the same sessions is the case of Lionel Reculus, discussed infra text accompanying notes 337-39. The previous case has number 469 , the following case has 470; in order to facilitate identification I assign it the number 469A. OBSP (Oct. 1754, \#469A), at 306 . 
in 1754, number 400 in 1755, and number 451 in 1756. At year's end the OBSP published an alphabetical index of the year's accused by surname, referenced to these assigned numbers of the accused. ${ }^{25}$ This system has bequeathed an excellent reference device to the modern researcher seeking to learn whether a person of known surname was tried at the Old Bailey in a given year or string of years.

The OBSP editors also used their system of assigned numbers in order to cross-reference repeat accused. Notations such as the following are common: in the case of Benjamin Ball, tried for stealing four linen handkerchiefs in October 1754, "See him tried last sessions for a street robbery, number $457 " ;{ }^{26}$ in the case of Godfrey Gilbert, tried for receiving a cart and harness stolen by William Robertson, "See Robertson's trial, No. 112, in this mayoralty."27 The reference to mayoralty in the latter case reflects a convention of dating by mayoral years similar to the regnal years used for reckoning the state calendar. The city of London reset its calendar in November when the mayoral office changed hands. ${ }^{28}$ The OBSP follow the city's official records in adhering to this convention, and the OBSP annual volumes run from the December sessions of one year through the October sessions of the next. (There was no November sessions; the eight OBSP sessions were scheduled to avoid the law terms when the royal judges like Ryder who helped staff

${ }^{25}$ In connection with a major change of format in December 1729, which included downsizing the pages, the editors explained:

By this Method, it will be in every one's Power to preserve them clean to the end of the Year, when there shall be an Alphabetical Index to the whole; so that by Binding them up together, they will have a Handsome Volume, and a Complete Annual Register of these Proceedings, and thereby make it, not worth any one's while to Reprint them in Volumes, which has been done at extraordinary Rates, and which could only be necessary, by the Destruction of those Printed on bad Paper, and in the Sheet Size; thus also, the Expense of twice Purchasing the same Accounts will be avoided.

OBSP (Dec. 1729), at 2. What the OBSP proprietor had in mind when complaining of reprints was in all likelihood not the literal reprinting of particular issues of the OBSP. Such reprinting would have infringed the OBSP's license and would in any case not have found a very satisfactory market much after the events. Rather, he probably meant those compilations of selected trials, clearly based on OBSP sources but usually reworked and embellished, that appeared under titles such as The Newgate Calendar, Select Trials at the Sessions House in the Old Bailey, and Malefactors' Register. For a valuable bibliography of these works, commencing with a two-volume set dated 1718, see G. Howson, THIEF-TAKer General: The Rise and Fall of Jonathan Wild 321, 324-25 (1970).

26 OBSP (Oct. 1754, \#498), at 323. For the cross-referenced case, see OBSP (Sept. 1754, \#457), at 302 .

${ }^{27}$ OBSP (Apr. 1755, \#169), at 158. For the cross-referenced case, see OBSP (Feb./Mar. 1755 , \#112), at 90.

2a See Corporation of London, The Corporation of London: Its Origin, Constitution Powers and Duties 16 (1950) [hereafter cited as Corporation History]. 
the Old Bailey were preoccupied with the work of the central courts in Westminster. ${ }^{29}$ )

2. The Reporter. Whereas next to nothing is known about the people who produced the earliest OBSP pamphlets, by Ryder's time the series was in the hands of an official London appointee. The reporter in these years, Thomas Gurney, became a figure of considerable renown in the history of shorthand reporting. ${ }^{\text {so }}$ Gurney was also the author of a book of instruction that purported to make shorthand "Easy to [readers of] the Meanest Capacity." It went through many editions from 1750 onwards and is incessantly advertised in the endpapers to the OBSP pamphlets of the period. ${ }^{32}$

Gurney's appointment as the official reporter for the Old Bailey seems to have commenced in 1748, although a biographer has adduced some evidence for thinking that Gurney had been reporting Old Bailey trials in a subordinate capacity for the previous decade. ${ }^{33}$ This would imply, as seems likely, that more than one reporter was needed to take down, transcribe, edit, and publish so many trials so rapidly. Gurney held the appointment until his death in 1770 , when his son succeeded him. ${ }^{34}$

The system of officially appointing the reporter can be traced

29 Blackstone mentions the scheduling of assizes to avoid the four law terms. $3 \mathrm{~W}$. Blackstone, Commentaries on the Laws of England 59 (Oxford 1765-1769)(4 vols.). By way of illustration, here is a calendar showing the staggering of law terms, assize sittings, and Old Bailey sessions for the main Ryder year, 1755:

$\begin{array}{llll}\text { Jan. 16-21 } & \text { Old Bailey } & \text { May 30-June 18 } & \text { Trinity term } \\ \text { Jan. 23-Feb. 12 } & \text { Hilary term } & \text { July 2-5 } & \text { Old Bailey } \\ \text { Feb. 26-Mar. 4 } & \text { Old Bailey } & \text { July 7-Aug. 16 } & \text { Summer assizes } \\ \text { Mar. 4-31 } & \text { Lent assizes } & \text { Sept. 10-16 } & \text { Old Bailey } \\ \text { Apr. 9-12 } & \text { Old Bailey } & \text { Oct. 22-25 } & \text { Old Bailey } \\ \text { Apr. 16-May 12 } & \text { Easter term } & \text { Nov. 6-28 } & \text { Michaelmas term } \\ \text { May 15-17 } & \text { Old Bailey } & \text { Dec. 4-9 } & \text { Old Bailey }\end{array}$

The Old Bailey sessions dates have been taken from the OBSP title pages. Law terms have been computed from information supplied in 3 W.S. HoLDSWORTH, A HISTORY OF ENGLISH LAW 674-75 (1922-1966) (16 vols.); HANDBOOK OF DATES For Students OF ENGLish History (C.R. Cheny ed. 1970). For assize dates, see infra note 94.

so 8 DNB, supra note 16, at 810-12 (entry by T. Cooper). A 49-page pamphlet, W.H. Gurney Salter, A History of the Gurney System of Shorthand (1924), is derived from the DNB entry and has no value.

a1 T. Gurney, Brachygraphy: or, Short-writing, Made Easy to the Meanest CapacITY (London 1750) (published in many editions). Among the descendants of this work: Gurney's Easy and Compendious System of Short Hand (2d Am. ed. Philadelphia 1799); A Text-Book of the Gurney System of Shorthand (18th ed. London 1884) (both volumes in Newberry Library, Chicago).

32 See, e.g., OBSP (Oct. 1754), at 341.

ss See $8 \mathrm{DNB}$, supra note 16, at 810 (entry by T. Cooper).

st Id. at 811. 


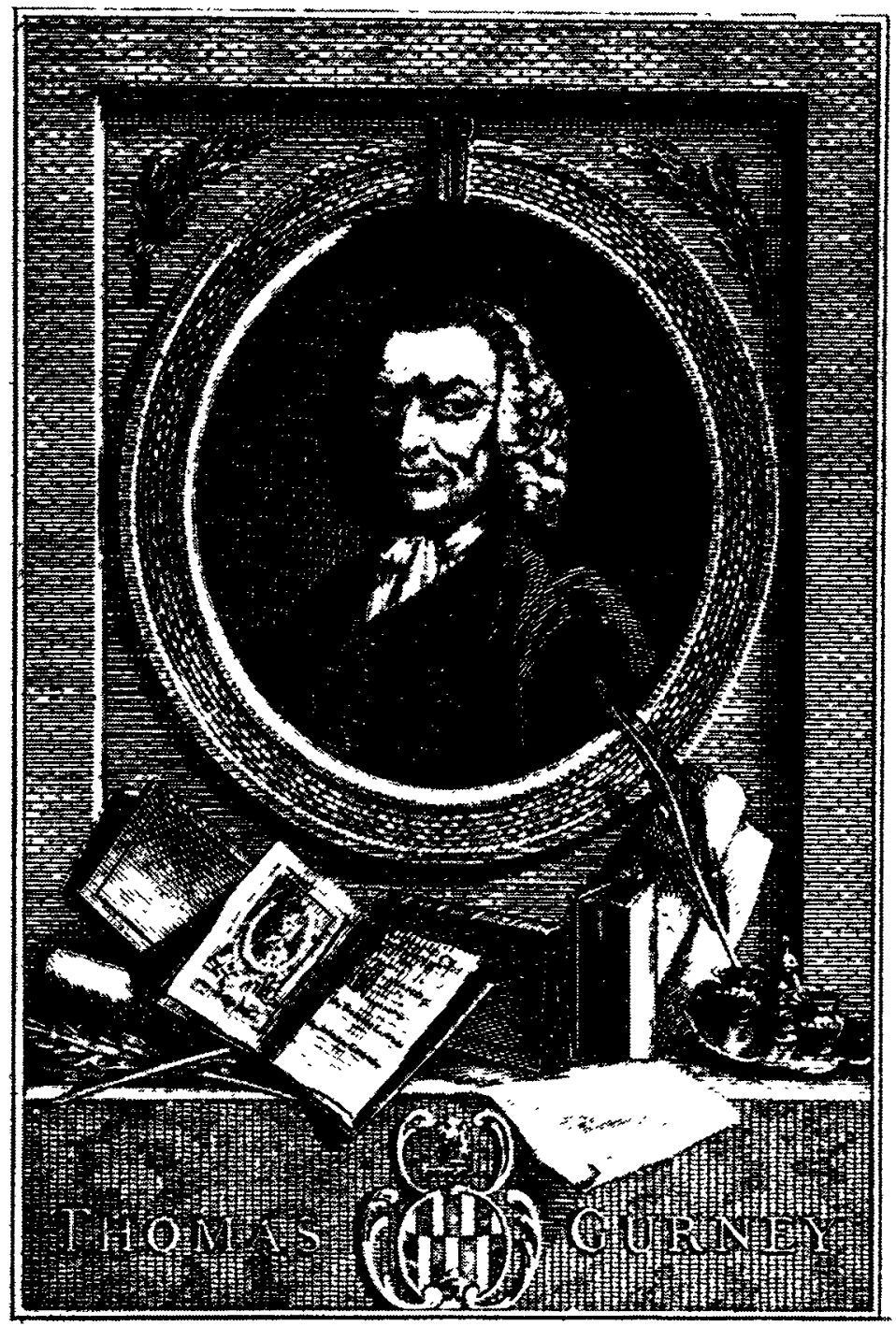


back into the seventeenth century. ${ }^{35} \mathrm{~A}$ reference for the year 1778 in the manuscript journal of the London Court of Common Council $^{36}$ indicates that the Lord Mayor had been collecting a fee, effectively a license tax, for "his privilege of publishing the Sessions paper." ${ }^{37}$ The quasi-official status of the OBSP is further evidenced in the duty of completeness that the reporters acknowledged at least from the early $1740 \mathrm{~s}^{38}$ Although the OBSP reported certain essentials of every case that was tried to verdict, ${ }^{39}$ not every case was the subject of the purportedly verbatim accounts that make the OBSP so vivid. I shall say more below about the principles that appear to have guided the editors in deciding which cases to publish more fully; the present point is that even when the OBSP report does not supply trial narrative for a case, it does supply a minimal record, a "squib" report of the essential details of the case-the name of the accused, the offense charged, the name of the victim/prosecutor, and the outcome or verdict. ${ }^{40}$ These indicia of quasi-official function seem incompatible with an editorial license to fictionalize.

3. Format. Each of the eight sessions of the Old Bailey began a new OBSP pamphlet, and in certain respects the contents were

ss The OBSP for December 1684 conclude with the text of a proclamation signed by the Mayor, James Smith: "I Do Appoint Robert Turner, to Print and Publish the Proceedings at the Sessions held at Justice Hall in the Old Bailey, and likewise the Execution of the said Prisoners, and that no other Person or Persons whatsoever presume to Print or Publish the same, or any part or parcel thereof." OBSP (Dec. 1684), at 8.

In an article just published, a historian of the English press reports manuscript evidence of licensing by the London authorities as early as 1678. Harris, Trials and Criminal Biographies: A Case Study in Distribution, in The Sale and Distribution of Books in ENGLAND FRom 1700, at 1,17 (R. Myers \& M. Harris eds. 1982).

so The Court of Common Council was the main deliberative and legislative body of the city of London. See Corporation History, supra note 28, at 50-56.

${ }^{37}$ Corporation of London Record Office [hereafter cited as CLRO], 67 Journal of the Court of Common Council 159r (Oct. 9, 1778): "A Motion was made and question proposed that the Sum of $£ 100$ be allowed and paid out of the Chamber of this City to every future Lord Mayor in lieu of his privilege of publishing the Sessions paper. . . The same was resolved in the Affirmative and ordered accordingly."

Further details concerning the rearrangement of the contract for producing the OBSP in this period appear in a broadside attributed to Joseph Gurney, the son and successor of Thomas Gurney. [J. Gurney], Mr. Gurney's Proposals Humbly Offered to the Consideration of the Right Honourable the Lord Mayor, the Court of Aldermen and the Common-Council of the City of london; for Changing the Mode of Publishing the Session Paper (n.p., n.d. [1778]) (Guildhall Library, London, shelfmark B'side 30.71).

ss See Article I, supra note 1, at 269 n.23.

so The OBSP seldom mentioned any case that was put over for trial or other discharge at sessions later than the one being reported. The Ryder diary does evidence motions and the like in a few of these, as do the manuscript records kept by the clerks in court.

10 Printer or scribal errors sometimes result in the omission of one or another of these details. 
stylized. It had long been customary for the opening paragraph to recite the names of the judges commissioned to serve at the sessions. By the Ryder years the OBSP editors had taken to assigning different symbols (asterisk, dagger, and so forth) to each judge's name in this opening paragraph. These symbols served as a code that the editors then used in the body of the pamphlet in order to signal at the outset of each case report which judge presided at that trial.

Following the recital of the judges' names, the pamphlet prints in parallel columns the names of the members of the two twelveman juries, one of Londoners and the other drawn from Middlesex, that tried all the cases. ${ }^{41}$ By the Ryder years the OBSP are taking the trouble to disclose in each case report which of these juries tried each case. (The allocation had been determined, of course, by the venue of the offense as charged in the underlying indictment.)

On the final page or pages of the concluding pamphlet for each sessions, after the last case report, the editors compiled a catalog of the sentences pronounced. The catalog groups the convicts by type of sanction and in order of gravity: first those sentenced to death, then those to transportation, to whipping, and so forth. By the Ryder years the editors were appending to this section a brief report of post-verdict developments that had occurred since the last pamphlet was published-mostly executions and pardons. ${ }^{42}$ Thus, it is usually possible to trace the fate of a capital convict in the endpapers of OBSP pamphlets for subsequent sessions.

4. Function. The editors' preoccupation with entertaining a nonlawyer readership is evidenced in several ways, of which the most unfortunate for the legal historical record is the bleaching out of legal detail. Even for extensively reported cases, the pamphlets typically preserve only the narrative of crime and detection, while deleting what would have interested lawyers about the conduct of these trials-appearances and motions of counsel, if any, and instructions and other incidents of jury control.

Further, the tastes of the lay readership appear to have guided the editors' selection of which cases to report more fully and which to treat as squib reports. Sensationalism prevailed. Homicides,

41 This practice is discussed for the earlier decades in Article I, supra note 1, at 273-77.

42 In other words, the pamphlets related post-verdict developments chiefly for capital cases. In the June 1752 pamphlet the editors announced: "In Order to render these Trials yet more acceptable to Gentlemen who preserve Sets of them, we shall from Time to Time give an Account of the Execution, or Alteration of the Sentences, of Persons convicted of capital Crimes." OBSP (June 1752), at 240. 
gang crimes, and thefts involving novel circumstances or unusually large amounts receive fuller treatment. So do virtually all cases with sexual overtones. For example, the October 1754 pamphlet supplies extensive verbatim from the trial of Elizabeth Upton, a domestic servant charged with stealing some kitchen staples and a few pence in coin. This sort of case usually was remitted to a squib report, but Upton's defense of implied consent resulted in a good deal of titillating testimony because she claimed to be pregnant by the victim/prosecutor. ${ }^{43}$ Sometimes the editors preserve narrative for pure comic relief. The April 1756 pamphlet reports a case in which two prostitutes were acquitted of stealing the prosecutor's watch; the prosecutor seems to have spoken with an accent, which is gleefully reproduced ("Ve vent ... on a bet; at de sam time I vas vit her on de bet she pick my poket. I never saw my vach since.")."4

The advertisements published in the endpapers of the OBSP also evidence a nonspecialist audience. In the 1756 mayoral year, Ryder's last, the OBSP were hawking (in addition to Gurney's shorthand manual) a book on fishing techniques called The Angler's Assistant, claiming to advise the reader, among other things, on "the various baits for each" sort of fish." Also advertised was "The celebrated Dr. Radcliffe's pile lozenges, universally esteemed an effectual Remedy for that troublesome Disorder," especially recommended for "Persons going abroad, to keep by them." 6

Certain quasi-official uses of the OBSP can be traced in postverdict practice, and this reliance upon the pamphlets tends to confirm the view that the OBSP reporters felt constrained not to falsify. Thus, the Old Bailey was prepared to treat an OBSP pamphlet account as authoritative when matters at a former trial became relevant. In a case that arose in Ryder's last sessions, April 1756 , the accused was charged with suborning perjury by having instituted a false prosecution for rape at the sessions the previous December. Gurney was called as the first witness, and according to the OBSP, he replied thus to the question whether he had brought the "minutes" he made at the December trial: "I expecting to be called upon this trial, before the [December] trial ... was put to the press, was very careful to examine and correct it, and am able to say the trial in the Sessions-Paper is a just copy of what passed

13 OBSP (Oct. 1754, \#506), at 331-35.

44 OBSP (Apr./May 1756, \#\#220-21), at 173, 174.

4s OBSP (Apr./May 1756), at 196.

4 OBSP (Dec. 1755), at 60. 
in court, as to the substance of the evidence given on that trial."47 Thereupon the clerk of the arraigns read out the trial testimony from the December pamphlet.

Another quasi-official use of the OBSP occurred in the executive clemency process. In his assize diary for August 1754, Ryder jotted down a remark of his colleague on the Home Circuit, Sir Michael Foster, then an experienced trial judge who was shortly to publish his famous work on crown law. ${ }^{48}$ Foster told Ryder that when the Recorder of London made his regular report to the King on the circumstances of the capital convictions following each sessions of the Old Bailey," he "takes his report from the shorthand writer's account of it." Among the Recorders' reports that survive in manuscript in the State Papers is one for a sessions (April 1755) at which Ryder sat. The report recites the evidence in the cases that resulted in death sentences, a few paragraphs to a case, much

17 Charles Wiesenthal, OBSP (Apr./May 1756, \#228), at 179, 180. For a similar appearance by Gurney in the celebrated case of Elizabeth Canning, see 19 ST. Tr. 283, 323-28 (1754).

4s On Foster, see generally the accounts in $8 \mathrm{DNB}$, supra note 16, at 500-01 (entry by G.F.R. Barker); E. Foss, BIographin JuRIDICA, supra note 16, at 278-79; 12 W.S. HoldswORTH, supra note 29, at 135-37. Foster's Crown Law is a transitional form between law report and treatise. M. Fostzr, Report of Some Prockedings on the Commission of Oygr and Terminer and Gaol Delivery for the Trial of the Rebels in the Ybar 1746 in the County of Surr[e]y, and of Other Crown Cases: To Which Are Added Discourses upon a Few Branches of the Crown Law (Oxford 1762) [hereafter cited as M. Foster, Crown LAw]. For further discussion of Foster's advice to Ryder on the 1754 assize circuit, see infra text accompanying notes 98-107.

49 Martin Madan described the mechanics as of 1785 :

The matter of reprieve is transacted differently in London and Middlesex, from what it is on the circuits. In the former, the criminals, after sentence, are remitted to the gaol, where they remain undetermined as to their fate, till the Recorder has made his report of their several cases to his Majesty in council. . . .

In the several counties where the assizes are held by the Judges on the circuits, reprieves are the immediate act of the Judge himself; who must know the truth of every case that he tries, so that he cannot be imposed on by misrepresentation, or by false report: and this renders him the more inexcusable to the public, if he reprieves improperly. He has no power to alter the sentence from one thing to another, as from hanging to transportation: but he has a power to reprieve, which (that the criminal may suffer as little even in mind as possible) his Lordship usually does-"before he leaves the town"-he then sends a recommendation to the Secretary of State's office, of such and such persons, as fit objects of his majesty's mercy; this is represented to the king, by whose command a letter is addressed to the Judges of the next assize for the county, ordering such and such to receive his majesty's mercy, on condition of transportation, going to the hulks, or as the matter is, according to the report sent by the Judge.

[M. Madan], Thoughts on Executive Justice, with Regpect to Our Criminal Laws, Particularly on the Circuits 103, 105-07 (2d ed. London 1785) (emphasis in original) [hereafter cited as M. Madan]. See generally 1 L. Radzinowicz, A History of English Criminal LAW AND ITS ADMINISTRATION BROM 1750, at 107-37 (1948-1968) (4 vols.).

so Ryder Assize Diary, supra note 21, at 16. 
as we would expect abstracts based on OBSP reports to appear. ${ }^{.1}$

A quarter century later we learn that the OBSP still were being used for this purpose. In 1778 Gurney's son and successor proposed to the Mayor and Council some changes in the licensing arrangements for the OBSP. One proposal reads: "[In order] That the Report to his Majesty of the Capital Convicts may not be delayed till the Publication of the Sessions Paper, the Short-hand Writer shall furnish the Recorder ... with a [provisional?] Copy of the Capital trials, within four Days from the End of each Session."52

\section{B. Ryder's Notes}

Since we intend to use Ryder's judge's notes as a legal historical source, and since this is a purpose that in all likelihood never crossed his mind, it is important to form some notion of the purposes Ryder did have in making these notes at the Old Bailey.

Modern English trial judges continue to take notes on the evidence heard before them in criminal cases, and for the main purpose that Ryder doubtless used his: as an aid to recollection in summing up for the jury. Ryder tended throughout his notes to underscore critical passages in the testimony, especially the details of eyewitness identification and alleged inculpatory declarations-just the sort of thing that figures centrally in judicial summing up. Ryder preserved testimony in dialogue form less often than the OBSP;"ss testimony that is reported in question-and-answer narrative in the OBSP usually appears in the Ryder notes as a synoptic declaration attributed to the witness without indication of the intervening questions. Ryder probably recorded his notes at pauses in the testimony or between witnesses' appearances, and synopsis sufficed. Thus, Ryder took his notes somewhat less faithfully than did the OBSP reporter, but he did not engage in the subsequent pruning that impairs the reliability of the OBSP.

Another indication that Ryder was making his notes primarily with a view to the summing up is that in some cases he omits to

s1 PRO, SP 36/132/296 ("Copy of the Recorder's Report, [April] 1755"). For a circuit letter containing recommendations for pardon by Ryder for persons convicted before him on the Home Circuit assizes of 1754 and 1755, see PRO, SP 36/133/69 ("Justices of Assize for the Home Circuit Certificate 16th Feb. 1756").

${ }^{83}$ [J. GuRNEY], supra note 37.

ss Although the OBSP preserve some question-and-answer dialogue, they omit or compress most. As far back as 1742 , the editors notified the readership that questions would be omitted from the reports when the answers showed what the questions must have been. OBSP (Sept. 1742), at 26. 
record the jury's verdict. ${ }^{54}$ Once Ryder had done his part in helping the jurors to deliberate on the verdict, he had discharged his duty. The clerks kept the official records of verdicts, and at the Old Bailey the Recorder of London passed sentence at the end of the sessions on the convicts, even those tried before other judges (except in convictions for murder, where sentence was passed immediately upon the return of the verdict)..$^{\mathrm{ss}}$

Especially in capital cases, however, judges' notes had a welldocumented function in post-verdict proceedings. Although appellate remedies in the modern sense were virtually nonexistent, the executive clemency process served something of the function of a system of appellate review. The pardon power was employed to set aside verdicts thought to be against the evidence or to ameliorate outcomes felt to be too harsh. The trial judge was invariably consulted in these matters, since he had overseen the trial and heard the evidence that had led to the capital verdict. The judge might instigate this review process, reprieving the convict on his own motion and referring the case to the monarch with a recommendation for commutation or pardon. Alternatively, the trial judge might find himself consulted by the executive in response to a petition from the convict or his supporters for clemency. Accordingly, a judge about to try any case in which serious sanctions, but especially the death penalty, might ensue knew that he might need to report on what happened at the trial, and this knowledge gave the judge an incentive to make and retain some note of the evidence. Because the petition might question the correctness of the outcome or seek mitigation on grounds of character or circumstances, nearly any type of trial evidence could become relevant to this post-verdict review.

The judges' replies in these clemency proceedings survive in considerable quantity in the State Papers. ${ }^{56}$ In some cases the judges mention that it had been their custom to rely upon their trial notes in framing their replies. We may take as an example a letter from William Moreton, who served as the Recorder of London throughout the Ryder years, replying in January 1755 to one of the secretaries of state concerning the petition of Jane

* For example, the case of Francis Pryer and John West, a crown-witness prosecution resulting in capital verdicts, OBSP (Apr. 1755, \#\#179-80), at 163; Ryder Notebook, supra note 19, at 22, 25; for a discussion of the case, see infra text accompanying notes 329-36.

ss See infra text accompanying notes 181-84.

se Senerally $1 \mathrm{~L}$. RADZINOwICz, supra note 49, at 107-37. I have summarized some important findings of unpublished research on these sources by P.J.R. King in Langbein,

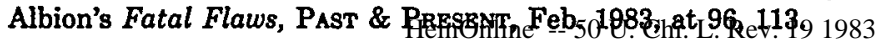


Blynn, who had been convicted of perjury before Moreton at the Old Bailey in October $1754^{\text {sz }}$ and sentenced to seven years' transportation. ${ }^{58}$ The secretary's inquiry reached Moreton on a sojourn at Bath. Moreton answered: "I tried her and she was found Guilty upon full Proof of her Crime. I can't transmit to your Lordship the particular state of her Case not having my Notes with me. But I very well remember that the Court were unanimously of opinion that she fully deserved the Sentence which was passed upon her."'68

Occasionally, we see Ryder entering in his notes remarks that appear to have anticipated these post-verdict proceedings. The case of Thomas Rolf, convicted of highway robbery before Ryder at the October 1754 sessions and sentenced to death, is a prominent example. ${ }^{60}$ The evidence indicated that Rolf, who had been apprehended at the scene, behaved politely and apologetically to his victim as he robbed her, telling her destitution led him to his crime. He was unable to find work, and his wife was about to deliver their third child. Ryder records in his notes that he urged the jury to convict, since "compassion could not justify finding contrary to truth," ${ }^{11}$ but after they heeded this instruction and found him guilty, the jurors "desired I would intercede for him. I said the Recorder would have an opportunity of representing it fully to His Majesty. And indeed I never in all my life met with a robbery on the highway so clearly proved to be the effect of mere necessity and committed for want of necessaries to maintain himself, wife big with child, and two infants." ${ }^{12}$ It seems likely that Ryder made this notation with a view toward advising the Recorder. Rolf re-

${ }^{67}$ OBSP (Oct. 1754, \#514), at 339.

ss This sentence was in addition to three months' imprisonment. Id. at 341 .

so PRO, SP 36/129/1 (Jan. 3, 1755). In a subsequent letter Moreton, still at Bath, writes that he has "ordered [a] statement of the Case . . . as it appeared upon the Trial" to be prepared for their lordships, and that he is enclosing a petition from persons who oppose pardoning her. PRO, SP 36/129/5 (Jan. 19, 1755). The petition survives. PRO, SP 36/129/6.

John Beattie has supplied me with references to three further instances in which such letters refer directly to the use of judges' notes. In 1737 Fortescue, J. apologizes for not being able to report on a case immediately "as my notes are not with me in the country." PRO, SP 36/43/31. In 1744 Probyn, J. writes regarding two men convicted of felony at Leicester assizes that "my Circuit book being locked up in my house and Study at London and [as] I [was] not able to Go thither for it" sooner, he has delayed writing until now. PRO, SP 36/58/15. Beattie finds Lord Loughborough writing in 1781: "Since I had the favor of your Letter I have examined the notes taken upon the Trials of the Thirteen Persons in the List enclosed . . . " PRO, SP 37/15/3.

60 OBSP (Oct. 1754, \#504), at 326; Ryder Notebook, supra note 19, at 18.

st Ryder Notebook, supra note 19, at 21.

12 Id. at 22. 
ceived a free pardon, ${ }^{63}$ that is, one not conditioned on transportation or some other sanction, even though the crown had to pay the prosecutrix the statutory forty-pound reward for apprehending and convicting him. ${ }^{84} \mathrm{~A}$ number of entries in Ryder's assize diary also deal with or appear to anticipate reprieve and pardon matters. $^{65}$

\section{Testing the OBSP Pamphlets Against the Notes}

In the case of Thomas Rolf, just discussed, the OBSP report omits all mention of Ryder's dialogue with the jurors, even though it transpired in open court and dealt with a matter of considerable juridical significance. Accordingly, Ryder's notes are our only source for his instructions and his remarks after receiving the verdict.

The important discrepancies between the Ryder notes and the OBSP follow certain patterns, which seem fairly intelligible in the light of our understanding of the purposes for which each source was produced.

1. Jury Control. Perhaps the most interesting of these patterns is the one evidenced in cases like Rolf's: The OBSP ignore all mention of the interaction of judge and jury. ${ }^{66}$ Indeed, we could easily understand if someone unacquainted with contemporary English criminal procedure were to form the mistaken impression from reading the OBSP case reports for the four Ryder sessions that juries had not even attended, much less decided these cases. Summation and instruction are systematically deleted; the verdict is disclosed in a single phrase ("guilty" or "acquitted") at the end of each report without indication of its provenance. ${ }^{67}$ The OBSP readership knew in general how these outcomes were reached, and as laymen they did not care about the legal detail.

Even when, as in the case of Mary Smith, tried before Ryder in October 1755 on the charge of murdering an employee, the OBSP account provides extensive narrative of the trial covering more than seven pages of pamphlet text, the verdict ("Guilty of Manslaughter") ${ }^{68}$ is tacked onto the witness testimony, with no ac-

13 OBSP (Jan. 1755, \# 504), at 80.

- PRO, T 53/45/353 (Treasury money book).

os See infra text accompanying notes 111-16.

of For the period from the mid-1670s to the mid-1730s studied in the previous article, the OBSP were more revealing on this matter. Article I, supra note 1, at 289-95.

"1 See supra notes 40-42 and accompanying text. Note, however, that the OBSP do give the names of the jurors for each sessions. See supra text accompanying note 41 .

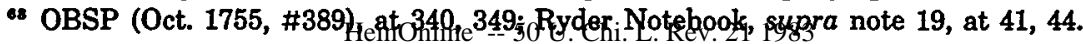


count of the intervening legal arguments and jury instruction. In his notes on the case Ryder records at length the submissions of counsel on the legal issue of premeditation and then writes: "I summed up fully, and concluded that I and my brothers [Clive] and Legge and the Recorder were all of the opinion that it was but manslaughter."69 The jury agreed.

Ryder sometimes found time to jot down a little of what he was telling the jury. John Taplin was tried before Ryder in October 1754 on an indictment charging theft from a dwelling house of a watch, valued at forty shillings, and of more than twenty guineas in money. The OBSP report of the outcome is as curt as possible, "Guilty 39s.," mo meaning that the jury convicted him but determined the combined value of what was stolen to be thirty-nine shillings (less than two guineas, hence well below the value charged in the indictment). Ryder's notes explain why. "The jury found him guilty to [the] value of $39 \mathrm{~s}$., which they did after I told them that 40 s. was necessary to make him guilty of felony that was without benefit of clergy. It is by Act of 12 Ann."7x Ryder thus records his own role in guiding the jury's prerogative of "valuing" the loot. Because the statute of 1713 to which Ryder refers withdrew socalled benefit of clergy ${ }^{72}$ from thefts of forty shillings' value or more when committed in a dwelling house, ${ }^{73}$ it foreclosed the primary ground upon which a convict could escape the death penalty for such an offense. The convention of the day, immortalized in Blackstone's phrase as the jury's "pious perjury,"74 was that the jury could "downvalue" the goods, in this instance to thirty-nine shillings, in order to consign the convict to the lesser sanction of transportation for seven years. ${ }^{75}$

Occasionally, Ryder tells us how he exercised his power to comment on the merits, that immensely influential device of jury control whose demise in the United States was long ago identified by Wigmore as a turning point in our legal history. ${ }^{78}$ For instance,

69 Ryder Notebook, supra note 19 , at $44^{\circ}$.

${ }^{70}$ OBSP (Oct. 1754, \#492), at 315, 319. See also Ryder Notebook, supra note 19, at 8.

"Ryder Notebook, supra note 19, at 11.

72 See infra text accompanying notes 142-55.

7s 12 Anne, ch. 7, § 1 (1713).

74 W. BLACKSTONE, supra note 29 , at 239.

75 Which is what happened to Taplin, whose transportation sanction is shown in OBSP (Oct. 1754, \#492), at 341 .

70 The American rule that "the judge's own view of the weight of the evidence is not to be stated to the jury . . . has done more than any other one thing to impair the general efficiency of jury trial as an instrument of justice." 5 J.H. Wigmore, A Treatise ON THE Anglo-American System of Evidence in Triars at Common $\mathrm{H}_{4}$ w 2551, at 557 (2d ed. 
in a case in which one erstwhile drinking companion prosecuted the other for highway robbery, Ryder reports: "I told the jury I thought there was no ground to find [the accused] guilty on this single evidence, and the jury found him Not Guilty." In one peculiar case, when Ryder "summed up favorably for [the accused]," the prosecution was allowed to call a further rebuttal witness who countered Ryder's view of the case and probably was decisive in leading the jury to convict. ${ }^{78}$ Occasionally, the Ryder notes attribute a rationale for the jury's verdict that we suspect originated in his instruction. Thus, in a case in which a child was acquitted of a theft, Ryder notes after the verdict: "Her father on my examining him said she was 12 years old excepting one month. The only color for finding her Not Guilty was her age, which made it a matter for their judgment whether she had sufficient discretion to be guilty of felony.""ra

2. Appearance of Counsel. In seven cases Ryder's notes disclose where the OBSP do not that prosecution or defense counsel was at work. ${ }^{80}$ We shall say more in Part VIII about representation

1923) (5 vols.).

For historical work I prefer the 1923 edition of Wigmore, which is more compact and less distracting than the gargantuan later revisions. Wigmore's treatment of the historical subjects discussed in this article does not change materially in later editions. Since later versions retain the section numbers used in the 1923 edition, my references can be located in any edition.

${ }_{77}$ Ryder Notebook, supra note 19, at 17, 18. See also Lloyd Davis, OBSP (Oct. 1754, \#511), at 338 (squib report).

78 Winifred Farrel, OBSP (Apr. 1755, \#181A), at 168; Ryder Notebook, supra note 19, at $25,26$.

70 Ryder Notebook, supra note 19, at 52, 53. See also Hannah Watkins, OBSP (Apr./ May 1756, \#178), at 162.

Another example, I suspect, occurs when Ryder explains the verdict in the case of Daniel Malone and Richard Dudley, charged with stealing several pounds' worth of rigging from a vessel on the Thames. OBSP (Oct. 1754, \#\#488-89), at 314; Ryder Notebook, supra note 19 , at 3 . Ryder reports the verdict, guilty to the value of 39 shillings, and adds:

Note: They found it to that value being under 40 s. because it was in reality a crime, if of 40s. value, without benefit of clergy. For the clergy is taken away from felony in stolen goods on board a vessel in a navigable river of $40 \mathrm{~s}$. value, but not if under it ... [by] the statute of 24 G.2 [24 Geo. 2, ch. 45 (1751)] and so would be only simple felony.

Ryder Notebook, supra note 19, at 4. Ryder must have instructed the jury about this special statute, which set a 40-shilling ceiling on benefit of clergy for river thefts, and he may have done it in a manner that invited the "downvaluing" that resulted.

- Prosecution counsel undisclosed in OBSP:

(1) William Cottom, horsetheft, OBSP (Oct. 1754, \#477), at 310; Ryder Notebook, supra note 19, at 6, 7 ("The counsel for the prosecutor, the Major, said that the Major desired [that the accused] might be recommended to mercy.").

(2) Abraham Davis et al., stealing rum from a warehouse, OBSP (Oct. 1755, \#\#390-92),

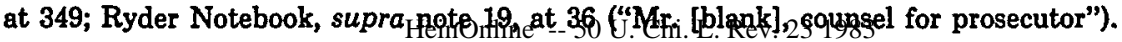


by counsel in the Old Bailey trials of the Ryder years. ${ }^{31}$

3. Deleted Testimony. Ryder's notes often preserve significant aspects of the trial evidence that the OBSP editors deleted from their narratives. For example, there are a couple of cases in which the OBSP state, "[t]he prisoner had nothing to say in his defense," ${ }^{82}$ which might mean that the accused simply kept silent. Ryder shows us that the accused did speak up, but that what he had to say was not consequential. Elsewhere, Ryder discloses that a pretrial confession that seems spontaneous as reported in the OBSP really was uttered in the hope that the accused would be granted immunity as the crown witness. ${ }^{83}$ In another case we learn from Ryder that the OBSP deleted most of the accused's defense

(3) Elizabeth Wright, stealing a silver creamer from the house of Lady Milbank, OBSP (Apr./May 1756, \#224), at 174; Ryder Notebook, supra note 19, at 57 ("Lucas, counsel for the witness"; Lady Milbank did not attend the trial but was represented by the servant who detected the theft, and who is almost certainly the "witness" Ryder means).

Defense counsel undisclosed in OBSP:

(1) Elizabeth Woodcock, theft of six shillings, OBSP (Oct. 1754, \#479), at 310 (squib report); Ryder Notebook, supra note 19, at 4, 5 ("Counsel for the prisoner crossexamined.").

(2) Oliver McAllister, forging a will, OBSP (Oct. 1754, \#500), at 324; Ryder Notebook, supra note 19, at 15 ("Mr. Gascoyne moved for defendant that he might be brought to his trial"; probably dismissed for want of prosecution).

(3) Charles Cane \& Thomas Williams, shoptheft, OBSP (Apr./May 1756, \#\#200-01), at 167; Ryder Notebook, supra note 19, at 45, 46 ("Mr. Lucas cross-examined."). (I infer that he represented Williams because he does not appear in Ryder's account of the second prosecution of Cane alone, which followed immediately, Ryder Notebook, supra note 19, at 46, and because his questioning appears to have been directed to distinguishing Williams from Cane. The career of Cane is discussed infra text accompanying notes 328-53.)

(4) Agnes Kirby \& Mary Hardis, OBSP (Apr./May 1756, \#\#210-11), at 171 (squib report); Ryder Notebook, supra note 19, at 54, 55 ("Counsel for Agn. Kirby cross-examined"; "Lucas, counsel for Hardy [sic], cross-examined.").

Lucas and Gascoyne seem to have had a heavy trade at the Old Bailey. In addition to the cases above where the men are named, the Ryder notes identify Gascoyne as one of the prosecution counsel in the murder trial of Mary Smith, OBSP (Oct. 1755, \#389), at 340; Ryder Notebook, supra note 19, at 41 . Further, Ryder reports that Lucas appeared on behalf of one Robert Ogle charged with murder, whose trial Lucas successfully moved to have postponed to the next sessions. Ryder Notebook, supra note 19, at 45. At that time he was acquitted on grounds of insanity, the OBSP report disclosing no participation by counsel. OBSP (June 1756, \#271), at 233.

S1 See infra notes 496-517 and accompanying text.

82 Joseph Gold, OBSP (Apr. 1755, \#183), at 170, 171; Ryder Notebook, supra note 19, at 28 ("The prisoner said he had no witnesses today, expecting my trial not till Friday. ' $I$ carry loads of beans and apples in Fleet Market." "); Charles Cane \& Thomas Williams, OBSP (Apr./May, 1756, \#\#200-01), at 167, 168; Ryder Notebook, supra note 19, at 45, 46 ("Both the prisoners now said only that they had no witnesses, and that the witnesses [against them] swore false.").

83 In the case of Elizabeth Beer \& Thomas Metcalp, OBSP (Apr. 1755, \#\#187-88), at 173; Ryder Notebook, supra note 19, at 30-32, discussed infra text accompanying notes 34143. 
from a case seemingly fully reported. ${ }^{84}$

Much less frequently we find the opposite phenomenon, the OBSP capturing something of juridical significance that Ryder omits. Thus, in a couple of hopeless cases Ryder appears to have lost interest toward the end and neglected to record the concluding statements that the OBSP attribute to each accused, presumably because the outcome was too clear for Ryder's note taking to have had a purpose. ${ }^{85}$ There also are instances in which passages garbled in Ryder's notes are intelligible in the OBSP. ${ }^{86}$

The most extensive of the omissions from the OBSP that Ryder permits us to repair occur in the thirteen of Ryder's forty-four trials for which the OBSP found room to publish only squib reports. ${ }^{87}$ Here we depend entirely on the Ryder notes for any view of the evidence and the conduct of the trials.

4. Reliability of the OBSP. The major lesson of our comparison is that Ryder never contradicts the OBSP, which means that the Ryder notes strongly corroborate the OBSP. The generalization that emerges is this: If the OBSP report says something happened, it did; if the OBSP report does not say it happened, it still may have. Legal historical researchers can rely upon the OBSP, but not for negative inferences.

Beyond omitting and deleting, the only other editorial practice that we can detect that verged on tampering had to do with the arrangement of the cases. Ryder's notes give us the sequence of his trials, which the official records confirm. ${ }^{88}$ The OBSP reports do not publish the trials in the order in which they occurred (nor in 34.

s Ann White, OBSP (Apr. 1755, \#193), at 181; Ryder Notebook, supra note 19, at 33,

ss Charles Frigatee, OBSP (Apr. 1755, \#182), at 169; Ryder Notebook, supra note 19, at 27; Mary Clinch, OBSP (Apr. 1755, \#197), at 183; Ryder Notebook, supra note 19, at 35.

so E.g., Benjamin Ball, OBSP (Oct. 1754, \#498), at 323; Ryder Notebook, supra note 19 , at 13,14. Ryder has a witness testify that the accused said during his pretrial examination before the sitting alderman that he had been transported seven years ago; the OBSP have the witness testify that, after leaving the alderman and en route to pretrial detention, the accused said that "he ought to have been transported seven years ago, and then he had been [i.e., would have been] a clear man by this time coming home again." In the case of Charles Cane and Thomas Williams, OBSP (Apr./May 1756, \#\#200-01), at 167; Ryder Notebook, supra note 19, at 45, 45-46, Ryder omits the confession competition discussed infra at text accompanying notes 348-49.

B2 The cases, by sessions and accused number, are: Oct. 1754, \#\#468, 469, 479, 484, 485, 511, 513; Apr. 1755, \#194; Apr./May 1756, \#\#184, 190, 210-11, 229, 230-31.

* Ryder supplies the dates within a sessions, for example, Ryder Notebook, supra note 19 , at 1, 8, 14 (October 23, 24, 25, 1754, respectively). Manuscript registers, dated by month and year of sessions, confirm Ryder's sequence of cases. See CLRO, Old Bailey Sessions Minute Book; Greater London Record Office (incorporating the former Middlesex Record Office) [hereafter abbreviated as MxRO], OB/SB/1, Old Bailey Sessions Book. 
any other purposeful sequence). ${ }^{89}$ The editors appear to have packaged them as they found convenient. The worst distortion that the Ryder notes allow us to detect in the OBSP. concerns another matter of sequence. In one case, ${ }^{90}$ the OBSP editors rearranged as part of the initial prosecution case a piece of testimony that was actually given in rebuttal, following the evidence for the accused. Although quite exceptional, this bit of tampering with the internal sequence of the trial shows us the scope of the license that the editors thought they had in processing their raw material. We use the OBSP as a historical source, therefore, with a constant sense of hazard, confident only that whatever their flaws, they were never fictionalized.

\section{Ryder's Assize Diary}

Before turning away from the subject of the sources to discuss some of the substantive issues they illumine, we must say a little about the other Ryder shorthand document that is serving us, the assize diary. ${ }^{91}$

Twice a year the judges of the central courts visited the counties of England as commissioners of assize to try before local juries both the cases of felony originating there and the civil cases that had been referred out from the central courts by means of the nisi prius sytem. ${ }^{92}$ The counties were grouped into six assize circuits; a pair of judges rode each circuit, and the convention was for one to try civil cases while the other sat "on the crown side" for the criminal calendar. ${ }^{93}$ During Ryder's two-year tenure as a judge, he rode the Home Circuit (covering Hertford, Essex, Kent, Sussex, and Surrey-the London collar counties) on the summer assizes held in August of 1754 and 1755. For the Lent assizes of 1755 and 1756, held in March, Ryder took the Northern Circuit. ${ }^{94}$

so One practice that seems purposeful was to arrange to have the two pamphlets for a sessions break in the middle of a case, leaving the reader in suspense about the outcome, manifestly in order to encourage him to buy the second pamphlet. This is done for three of the four Ryder sessions (Apr. 1755, Oct. 1755, Apr./May 1756). It must have been deliberate since it could have been so easily avoided.

*o Francis Pryer et al., OBSP (Apr. 1755, \#\#179-81), at 163, 168 (testimony of Francis Farral); Ryder Notebook, supra note 19, at 22, 24.

11 See supra note 21 and accompanying text.

92 On the assize system, see generally J.S. Cockburn, A History or Encrish Assizes 1558-1714 (1972).

93 See infra notes 122-23 and accompanying text for further discussion of this allocation between the two judges.

* Circuit appointments were announced in the London Gazette. Ryder's: summer 1754, id., July 2-6, 1754, at 1, col. 2; Lent 1755, id., Feb. 15-18, 1755, at 2, col. 2; summer 1755, id., 
The document that we are calling Ryder's assize diary probably ought not to be reckoned as a species of judges' notes, but rather as a travel diary. Since Ryder was on journey for official rather than recreational purposes, some of what he jotted down touches the detail of his judicial duties, and this is what most interests the legal historian. But these are scattered passages. The predominant subject is travelogue: coaches and travel companions; the routes taken; condition of the roads; appearance of the landscape; architecture of the houses visited; receiving and extending dinner invitations; menus and meals; chit-chat about relatives and acquaintances encountered on the tour-their appearance, manners, health; and the receipt of gratuities, especially venison and other table fare. Some of what Ryder records seems so intimate-his urinary problem, his self-satisfaction with a speech, or his perplexity at the turbulent character of another judge ${ }^{95}$-that we have no doubt that Ryder made this document for private reflection.

The diary bears a faint resemblance to the seventeenth-century assize diary of Rokeby, J., which was published about a century ago. ${ }^{88}$ Ryder's diary covers his activities during his two turns of service on the Home Circuit, but it does not mention his two Lent assizes on the Northern Circuit. ${ }^{97} \mathrm{He}$ may have kept a similar volume for the Northern Circuit that has gone astray. The explicitly legal entries in the diary consist, broadly speaking, of two sorts of material: tips from fellow professionals and remarks touching the trials he conducted.

On the summer assizes of 1754 Ryder was handling his first criminal trial calendars. Being new to the business of judging, he was eager to pick up pointers. He could scarcely have had a better qualified instructor than his fellow assize commissioner, Michael Foster-a friend from Ryder's youth ${ }^{28}$ who was already long experienced in criminal adjudication ${ }^{99}$ and who became one of the prin-

June 21-24, 1755, at 2, col. 1; Lent 1756, id., Feb. 21-24, 1756, at 2, col. 1.

* Ryder Assize Diary, supra note 21, at 14, 27, 26.

* The Diary of Mr. Justice Rokrby (W. Boyd ed. 1887).

n Ryder did sit. See PRO, Assi. (Assizes) 41/4 (gaol book, unpaginated, entries consecutive by date); PRO, Assi. $42 / 7$ (minute book, unpaginated, entries consecutive by date).

* The diary that Ryder kept in his youth during the years 1715-1716, RYDBR STUDENT DLARY, supra note 17, records discussions with Foster, id. at 226, 234, 361, 362, 365, 372, 373. The two men were reared in Protestant dissenter circles, which was the basis of these early contacts.

- Foster had been Recorder of Bristol from 1735. See E. Foss, Biographia Juridica, supra note 16, at 278. In that capacity he presided over the trial of Samuel Goodere for murder, a case that found its way into the State Trials series. See 17 ST. TR. 1003 (1741), 
cipal authorities of the age. ${ }^{100}$ Ryder also took tips on practice matters from the clerk of assize for the Home Circuit, a barrister named Jerome Knapp. ${ }^{101}$

Entries like the following abound: "Brother Foster having told me that he never suffered more than one counsel of a side to examine or cross-examine [in civil cases] and not to let a second counsel sum up, I took the same method in this case ...."102 Or again: "Brother Foster says he never knew a woman sentenced to be whipped, but clerk of assizes says it is common, and then they are privately whipped." 103 Other subjects on which Ryder preserved advice from Foster include: how to pronounce criminal sentences; ${ }^{104}$ when grand and petty jurors and justices of the peace (JPs) should be fined for nonattendance or premature departure; ;05 $^{105}$ the construction of particular statutes; ${ }^{108}$ and the mechanics of reprieving convicts for clemency. ${ }^{107}$ From the clerk of assize Ryder records a valuable series of remarks about how the then-recent statutes of 1752 and 1754 for subsidizing the costs of criminal prosecutions were being implemented. ${ }^{108}$

Unlike Ryder's judge's notes, the diary does not contain the minutes of oral evidence transcribed in court. There is no trial verbatim. Ryder almost certainly composed the diary from recollection at the end of the day (sometimes after several days). The substance of trial evidence is given only exceptionally. ${ }^{109}$ The contents

discussed in Article I, supra note 1, at 313-14. Foster became a King's Bench judge in 1745. See E. Foss, Blographia JuRIDICA, supra note 16, at 278, 279.

100 See supra note 48.

${ }^{102}$ Ryder identifies Knapp by name once, Ryder Assize Diary, supra note 21, at 5. Knapp is shown as the incumbent for the Home Circuit in John Chamberlayne, Magnas Britanniae Notitia: Or, the Present State of Great Brttain (pt. 2) 275 (London 1755). (I owe this reference to John Beattie.) Knapp signed the indictments tried on the circuit. See, e.g., PRO, Assi. 35/194/2 (Essex 1754). Knapp's call to the bar in 1750 is recorded in 1 Register of Admissions to the Honourable Society of the Middle Temple 322 (H.A.C. Sturgess ed. 1949). Knapp became a bencher in 1778. See The Middle Temple Bench Book: Being a RegistzR of Benchers of Thz Middle TkMple 264 (A. Ingpen ed. 1912).

${ }^{103}$ Ryder Assize Diary, supra note 21, at 8.

${ }^{103}$ Id. at 15. Elsewhere in the diary Ryder reports how benefit of clergy is granted. "The method is when a clergyable felony is found, the prisoner is asked by a clerk of arms [sic; arraigns] why judgment of death shall not be passed against him; the prisoner falls on his knees and begs transportation, and then no sentence of death is pronounced, but transportation or whipping." Id. at 13. Benefit of clergy is discussed infra text accompanying notes 142-55.

106 Ryder Assize Diary, supra note 21, at 6-7.

105 Id. at 12.

${ }^{108} \mathrm{Id}$. at 13.

${ }^{207}$ Id. at 15-16; see also id. at 24.

${ }^{108} \mathrm{Id}$. at $7,13,16,25$. See infra note 495.

${ }^{109}$ See the case of Frances Cheek, infra text accompanying notes 473-74. 
of the diary seem selected for the unusual and noteworthy, by contrast with the Old Bailey notes that track the courtroom routine. The diary is so far from serving the purposes of judges' notes that we may wonder whether Ryder made a separate assize notebook that is now missing. ${ }^{110}$

One advantageous result of Ryder's bias in the diary towards the relatively exceptional and memorable aspects of his judicial work is that he made considerable mention of his thinking in the life-or-death business of granting reprieves for executive clemency. These were post-trial decisions, and they fell outside the scope of

110 I have been led to this conjecture primarily by the great disparity in detail between the diary and Ryder's subsequent report to the monarch in a clemency matter, the case of Richard Tickner, further discussed infra text accompanying note 114. Ryder's report, which survives in the State Papers, recites considerable detail about the evidence that was presented against the convict at his trial, and this detail is not to be found in the diary. Ryder must have had another source, other notes, from which to take the following information:

It appeared by the Evidence of Jeremiah Sibbets, that as he was riding from Croydon to Godstone on the 25th of April last about Eleven in the Morning the Prisoner came up to him, presented a Pistol to his Breast and demanded his Money with a Curse, which on a Second like demand he delivered to him the amount of 14 Shillings.

It appeared by the Same and other Witnesses that the Country being alarmed with several Robberies on the Highway, the Prisoner was taken on the 29th of the Same April and 3 Pistols loaded with powder and chalk stones cut like pebbles found upon him, that he would give no account at first how he came by the Pistols, or what his name was, but when he was brought before a Justice of Peace said his name was Tickner, and that he was a malster.

The only Witness Produced for the Prisoner was John Gilbert, who swore [that Tickner] had been his servant in the Business of a Malster 3 years, and that he had discharged [Tickner] from his services at the Witness's own House about 15 miles from the place of the Robbery, on the Same 25 April, between 4 and 5 in the Afternoon, and that the Reasons of discharge were partly because he had given him leave on the 23rd of the Same month to See his Friends, expecting him home the Same day, and he did not return till the 25th; and partly because he, the Prisoner, had taken a Malthouse within a Quarter of a Mile of the Witness's house. He also swore, the Prisoner had behaved very honestly towards him, and had a good Character in the neighborhood.

PRO, SP 36/128/77-78 ("Lord Chief Justice's Report of the Case of Richard Tickner, a Convict," signed by Ryder and dated September 7, 1754). In the diary, none of this trial evidence is recorded. See Ryder Assize Diary, supra note 21, at 16, 17. The trial occurred on August 24, 1754. PRO, Assi. 31/4/61 (Home Circuit agenda book). It is inconceivable that Ryder would have remembered such detail for the two weeks between August 24 and September 7.

Joanna Innes has suggested to me another possible source from which Ryder might have taken the information recited in this letter. There was a series of pamphlet reports for Surrey assizes (The Proceedings of the Sessions ... for the County of Surrey) that resembled the OBSP. See Article I, supra note 1, at 272 n.29, discussing seventeenth-century exemplars and summarizing Beattie's work with these sources for the eighteenth century. Although none appears to have survived for the assizes in question (summer 1754) it is likely that one was produced, since we have editions from the sessions immediately preceding (Lent 1754) and from another held shortly afterwards (summer 1756). Ryder may have had access either to the published pamphlet or to the shorthand reporter. 
ordinary judges' notes of courtroom evidence such as the Ryder Old Bailey notebook.

Because recent Marxist writing ${ }^{111}$ casts aspersions on the judges' motives in administering the pardon process, our evidence respecting Ryder's practice merits special attention. Ryder based his decisions in these matters on the merits of the cases. Concluding the 1754 Surrey assizes at Guildford, Ryder noted that he let two burglars hang because "[i]t was a very plain and bad case," but he reprieved a horsethief "because the evidence doubtful," a sheepthief "because the evidence not clear," and a pickpocket against whom the evidence amounted in Ryder's view "not quite [to] a clear case."112

At the same assizes Ryder resisted what he thought were unjustified requests for clemency in two cases of highway robbery, even though men of importance importuned him to reprieve the convicts. Richard Gilbert "was recommended to reprieve by Creswick and Andrews his master, being but 20 years old, but [the conviction] being for highway [robbery, and Gilbert having been convicted of two offenses committed the same day, I] did not reprieve him."11s In the case of Richard Tickner, Ryder refused to reprieve although requested to do so by Arthur Onslow, the Speaker of the House of Commons, Richard Onslow, the lord lieutenant of Surrey, and Henry Talbot, the high sheriff of Surrey. Arthur Onslow went to the King; Ryder's opinion was sought, and he records it thus: since "there was no reason to doubt [that Tickner had committed the crime] and there were no circumstances of alleviation, I could not take on myself to say he was an object of mercy";114 the King let him hang. At Horsham assizes a few days earlier Ryder sentenced to death a man named Millet for horsetheft. His diary records: "The clerk of assizes pressed me much to transport Millet, the hosteller, but I refused it because it seems to have been his practice [that is, he was a multiple offender], ... and nobody spoke to his character."116 Ryder's handling of reprieve and pardon matters was principled. He was trying to take into account factors that ethical sentencing officers still consult. ${ }^{116}$

11 Hay, supra note 21, at 43-46.

122 Ryder Assize Diary, supra note 21, at 17-18.

11s Id. at 17.

114 Id. at 17, 18. Both Onslow's letter and Ryder's reply, quoted supra note 110, survive in the State Papers. PRO, SP 36/128/67 (Sept. 3, 1754); PRO, SP 36/128/77 (Sept. 7, 1754).

116 Ryder Assize Diary, supra note 21, at 13.

${ }^{116}$ The discussion in this and the previous paragraph is based on Langbein, supra note 56 , at $112-13$. 


\section{A Collegial Trial Bench?}

From the standpoint of modern Continental criminal procedure, one of the more striking peculiarities of the Anglo-American tradition is the absence of a collegial bench in cases of serious crime. In a criminal jury trial, a single judge presides, directs the jury, and sentences. When the accused elects bench trial, that is, trial without jury (an American invention without true counterpart in England for cases of serious crime), ${ }^{117}$ a single judge finds the facts, applies the law, and sets the sentence. In the European tradition, criminal adjudication is collegial. In cases of serious crime, even when the system employs jurors or juror-like lay judges, the judicial role is frequently shared by several, usually three, professional judges. ${ }^{118}$ In the nineteenth century when the Continental codes were shaping the contours of the modern court systems, collegiality was thought to be an important safeguard against judicial caprice or corruption. ${ }^{110}$

When we turn back to the OBSP and the Ryder notes for the mid-1750s, which depict what was then the principal criminal trial court of the Anglo-American world, we find it operating with a trial bench that was collegial in form and to some extent in fact.

The nominal trial bench at both the Old Bailey and the provincial assize courts was quite numerous, but we must avoid confusing the supernumerary English trial commissioners with a truly collegial bench of professional judges. In the English courts the royal judges conducted criminal trials for felony under two commissions, gaol delivery and oyer and terminer. The tradition was already centuries old by Ryder's day for the commissions to designate central and local dignitaries and local justices of the peace by the dozens to serve with the royal judges. However, the so-called quorum clause in the commissions ensured that these people were merely decorative, by insisting that the powers of the commission were not to be exercised without the participation of the judges. In practice there is no indication that they interfered with the profes-

117 Towne, The Historical Origins of Bench Trial for Serious Crime, 26 AM. J. Legas Hist. 123 (1982).

118 G. Casper \& H. Zeisel, Der Laisnrichter im Strarprozesss 9 (1979). The modern German version of such court structure is discussed in Langbein, Mixed Court and Jury Court: Could the Continental Alternative Fill the American Need?, 1981 AM. B. Found. REsearch J. 195.

119 See, e.g., Jescheck, Das Laienrichtertum in der Strafrechtspflege der Bundesrepublik Deutschland und der Schweiz, 94 Schweizkrische Zertschrift pURR Straprecht 229, 232-33, and sources cited 232 n.8 (1977). 
sionals' conduct of the trials, ${ }^{120}$ although many did attend. Ryder's notes show us that two of the London aldermen (who were by virtue of their office also justices of the peace for the city) were sitting with him at an Old Bailey trial in October 1754; they complimented Ryder on "what I said to the jury"121 after Ryder had warned against compassion in the trial of a pickpocket.

On the assize circuits, two professional judges were named for each semiannual sessions, but there was a special reason why they did not have occasion to join together in the conduct of criminal trials. The assize judges were also exercising a nisi prius commission to try civil cases pending on their circuits. The convention was for one of the judges to try the civil cases while the other judge tried the criminal calendar in a separate room. ${ }^{122}$ Ryder's assize diary supplies a good deal of incidental information on how the two judges coordinated their work. When the judge with the lighter caseload, typically the criminal calendar, completed his trials, he was free to go off on personal business. In one instance Ryder's cojudge "having finished his Crown [i.e., criminal] cases on Wednesday morning tried four [civil] cases for me Wednesday afternoon. Thursday morning early he went to London." ${ }^{123}$ There is no men-

${ }^{120}$ On the quorum clause as revised in the Elizabethan period, see J. LANGBEIN, Prosecuting Crime in the Renaissance: England, Germany, France 115-17 (1974). We speak only of assize courts. At the courts of quarter sessions and their urban/municipal equivalents, the bench consisted of the attending JPs, who of course voted; see, for example, the account of a split vote at the October 1776 Middlesex quarter sessions on the question whether to discharge a disobedient trial jury, in B. Davis, A Proof of Eminence: The Lipe of Sir John Hawkins 201-02 (1973).

131 Ryder Notebook, supra note 19, at 7. See also Thomas James, OBSP (Oct. 1754, \#481), at 311.

122 See supra notes 92-93 and accompanying text. According to a report in Henry Fielding's newspaper, the Covent Garden Journal [hereafter cited as CGJ], both assize judges sat together in a celebrated murder case, the Jeffryes affair, which was tried at Essex Lent assizes in Chelmsford in 1752. Fielding's clerk, Joshua Brogden, attended the assizes, see CGJ, Mar. 14, 1752, at 2, col. 2, and he was doubtless the source of the unsigned report on the Jeffryes case. The trial started at about 7:00 AM. Immediately at the arraignment "[d]ebates arose by Counsel for the Prisoners" challenging the sufficiency of the indictment, "upon which Mr. Justice [Martin] Wright sent for Mr. Justice [Michael] Foster, to be present at the said Debates, which lasted by the Counsel on both Sides till ten o'Clock, when it was over-ruled." Id. at 3, col. 3. For other reportage on the Jeffryes case, see 33 GeNTLEMAN's MaG. 121 (1752); for pamphlet editions see A Biblography of EighteENTH-CENtURy Legal Literature 348 (J.N. Adams \& G. Averley eds. 1982) (entries under Swan, John) [hereafter cited as Eightzenth-Century Bibliography].

12s Ryder Assize Diary, supra note 21, at 26 (Chief Justice Willes was the co-judge in question). Elsewhere in the diary Ryder notes how the two judges coordinated subsequent sittings: "It is usual on the circuits for the judges, when they go from the bench, to adjourn to the other court that is sitting, and when that court rises, to adjourn to the other court which is intended to sit first afterwards . . . ." Id. at 19. 
tion in Ryder's assize diary of his co-judge sitting with him in the conduct of any trial, civil or criminal.

At the Old Bailey, however, the Ryder-period sources present a more complicated picture. The Old Bailey had no civil side, so that the three or four judges (including the Recorder of London) were all assigned to the large criminal calendar of the metropolis. We have already mentioned in other contexts evidence indicating that all the judges were involved in some cases. We quoted from Ryder's notes in the case of Mary Smith that he "concluded [his summation by saying] that I and my brothers [Clive] and Legge and the Recorder were all of the opinion that it was but manslaughter."124 And we reproduced from the State Papers a certificate from the Recorder, Moreton, in response to a pardon petition from Jane Blynn, in which he apologized for not having his notes in hand but said that "I very well remember that the Court were unanimously of opinion that she fully deserved the Sentence which was passed upon her."125 Ryder records in his notes for October 1754 that Henry Bathurst, one of the other judges commissioned for the sessions, differed with him about a point of law in one case. Ryder thought that the accused was liable as a principal, on which interpretation the jury convicted him; Bathurst regarded the accused as a mere aider and abettor who should have been acquitted because the indictment did not so charge. ${ }^{126}$

Accordingly, in some Old Bailey cases we can be confident that more than one judge was sitting. Yet these manifestations of collegiality look more incidental than systematic, and there are a variety of indications that the norm was trial before a single judge. ${ }^{127}$ Initially, we recall that in every case at the four sessions we are studying, including those cases in which we have solid evidence of collegial participation, the OBSP identify a single judge as "the Judge by whom the Prisoner was tried."128 Ryder's notes confirm all but one ${ }^{129}$ of the OBSP attributions to him, and he does not record having participated in the trials that the OBSP attribute to the other judges. When his notes are sufficiently detailed, they make it clear that his was the active judicial role. We

124 Supra text accompanying note 69.

${ }^{125}$ Supra text accompanying note 59.

128 Daniel Malone \& Richard Dudley, OBSP (Oct. 1754, \#\#488-89), at 314; Ryder Notebook, supra note 19 , at 4.

${ }^{127}$ For a nineteenth-century holding that only a single judge need actually sit at an old Bailey trial, see Leverson v. Regina, 4 L.R.-Q.B. 394, 403-04 (1869).

${ }_{128}$ E.g., OBSP (Oct. 1754), at 306, discussed supra text preceding note 41.

120 Elizabeth Broomhall, OBSP (Oct. 1755, \#375), at 332. 
find no further instances of collegial participation in Ryder's cases beyond those just quoted. Likewise, in the case of Jane Blynn for which Moreton referred to collegial support in the post-verdict certificate just discussed, the OBSP state that Moreton tried the case, and Moreton began his certificate by reciting that "I tried her."130

In his assize diary Ryder records a remark about patterns of attendance at the Old Bailey that throws some light on the question we are discussing. Ryder rode his first assize circuit in the summer of 1754, before his first Old Bailey sessions that October. We have seen that he felt himself to be a novice, and that he recorded a good deal of advice, mostly from his co-judge Foster, about the details of the work of a criminal trial judge. At the end of the diary for 1754 appears another paragraph of this character, probably added somewhat after ${ }^{181}$ Ryder's return from the assizes, attributed to "C.B.," whom I infer from context to be the Chief Baron of the Court of Exchequer, Thomas Parker. ${ }^{132}$

C.B. told me that the C.J.s [chief justices of the three royal central courts] seldom come earlier to Old Bailey than 10 or 9 . That he never stays after 8 at night unless in a trial then depending, and C.J.L. [Chief Justice William Lee, Ryder's immediate predecessor as Chief Justice of King's Bench] seldom sat there after 4 and then went home to dinner. And that at the sessions in September seldom any judges attended. And I think I can see that the Chiefs exercised their discretion pretty much in their attendances. I think to come late some days at Old Bailey on purpose to be present when a trial being on I may hear how the judge sums up and examines witnesses. ${ }^{133}$

The comment that "seldom any judges attended" a certain month's sessions is a little misleading. In this usage "judge" means the royal court judges. The Recorder of London attended, and he had full judicial authority and must have tried as much of the calendar as was necessary. The full passage makes it clear that the

130 Supra text accompanying note 59.

131 The paragraph to be quoted immediately precedes the final entry for 1754 , Ryder Assize Diary, supra note 21 , at 18, a paragraph that was certainly added after the conclusion of the assizes; in the final entry Ryder discusses his report to the monarch in the Tickner case, discussed supra note 110. We have shown from the State Papers that Ryder dated the report September 7. The last assize business was transacted on August 26, see PRO, Assi. 31/4/63-64 (agenda book); Ryder notes in his diary that he and Foster both set out for home the day after. Ryder Assize Diary, supra note 21, at 16.

182 For biography on Parker, see E. Foss, Brographia JurIDICA, supra note 16, at 501.

2ss Ryder Assize Diary, supra note 21, at 18. 
royal judges, and especially the three chief justices, felt no obligation to attend systematically, or indeed to attend at all. Certain notations in Ryder's Old Bailey notes for the four sessions in 17541756 appear to confirm that not all of the judges commissioned for the sessions attended throughout. ${ }^{134}$ We also have good reason to suspect that Ryder attended the October 1755 sessions on only one of its four days. ${ }^{135}$

We are far from having a clear picture of how the Old Bailey bench was staffed; in particular, we have no idea how the job of presiding over the various cases was allocated among the judges who did attend. However, our sources do permit us to conclude that a collegial bench in the Continental sense was not in operation. Only the Recorder appears to have felt an unqualified duty of attendance. Every case was treated, both by the OBSP and by the judges themselves, as having been tried by a single judge. This presiding judge was joined occasionally by one or more colleagues, and he occasionally drew upon their views in a manner that resembles the work of a truly collegial court. But such happenstance collegiality falls well short of serving the purposes for which the Continental systems have insisted on collegial courts. The main reason that the English were not particularly concerned to have a collegial bench was, of course, that the jury system served as an alternative safeguard against judicial excesses, since it divided the adjudicative power and allocated much of it away from the bench. ${ }^{136}$

Having pointed out a few differences in court structure between the Old Bailey and provincial assizes (more frequent sittings, more royal judges in the trial commission, and the Re-

134 E.g., Ryder begins his notebook for April 28, 1756, remarking, "Brother Clive in court." Ryder Notebook, supra note 19, at 45. For April 30 there is a similar note: "Brothers Clive and Legge present with self." Id. at 56.

18s It appears that Ryder sat only one day in the October 1755 sessions, October 24, id. at 36. The OBSP confirm that he sat as the trial judge in only three or four cases in the October 1755 sessions: Elizabeth Broomhall, OBSP (Oct. 1755, \#375), the uncertain case cited supra note 129; Mary Smith, OBSP (Oct. 1755, \#389), at 340; Ryder Notebook, supra note 19, at 41; Abraham Davis et al., OBSP (Oct. 1755, \#\#390-92), at 349; Ryder Notebook, supra note 19, at 36; John Carrol, OBSP (Oct. 1755, \#394), at 358; Ryder Notebook, supra note 19 , at 40 .

${ }^{136}$ See, e.g., Blackstone's account of the criminal jury trial as a safeguard against "the violence and partiality of judges appointed by the crown . . . . Our law has therefore wisely placed this strong and two-fold barrier, of a presentment and a trial by jury, between the liberties of the people, and the prerogative of the crown." $4 \mathrm{~W}$. BLACKSTONE, supra note 29, at 343. On the importance of this theme in the seditious libel controversy in the second half of the eighteenth century, see T. Green, The Jury, Seditious Libel, and the Criminal Law, text accompanying notes $63 \mathrm{ff}$. (William Andrews Clerk Memorial Library Lecture, Feb. 28, 1981) (forthcoming 1983). 
corder's role as a permanent judge and sentencing officer), we should emphasize that these were details of comparatively little consequence. The principles of proof and trial applied equally in the metropolis and in the countryside. Dudley Ryder and his fellow royal judges alternated tours of service on the assize circuits and at the Old Bailey. English criminal procedure was very much a national system. To be sure, the caseload evidenced in our Old Bailey sources reflects the urban setting. We see more shoptheft and less sheeptheft in London than we would find in Lincolnshire or Lancashire. Although (as I shall show in Parts IV and V) the special problems of policing and prosecuting serious crime in the metropolis had a material bearing on the ultimate shape of trial procedure, there was no means of confining that development to London. What was created was not London law but English law.

\section{Crimes and Punishments}

The Old Bailey in the mid-1750s was a court for the trial of serious crime, that is, felony. A grievous misdemeanor might on occasion be tried there, ${ }^{137}$ but the entire calendar of an Old Bailey sessions typically contained only felony cases. In theory the distinguishing characteristic of a felony was that it was punishable by death: "every Person attainted of Felony ... shall lose his life, and be hanged between Heaven and Earth, as unworthy of both."1s8 Grand larceny, defined as theft of goods or money worth more than a shilling, was by far the most commonly prosecuted offense at the Old Bailey. ${ }^{139}$ Hence, in theory, practically every accused at the Old Bailey was on trial for his life. No feature of English criminal law became more notorious, or aroused more indignation, than the nominally capital character of small thefts. A seventeenth-century tractitian reproached English law in the following words, which were echoed incessantly in reformist literature down into the nineteenth century: "Doest thou value the life of a man no more than so as to cut it off for the value of a garment, yea even of a pair of shoes or stockings or a shirt or any other thing above such a piece of money"?140

${ }^{237}$ E.g., Jane Blynn, OBSP (Oct. 1754, \#514), at 339 (perjury), discussed supra text accompanying notes 57-59. 1618)

${ }^{198}$ M. Dalton, The CounTrey Justice, ch. 163, at 403 (London 1682) (1st ed. London

139 See infra notes 162-63 and accompanying text.

160 W. Tomm non, Seven Particulars 9 (1658), cited in D. Veall, The Popular MoveMENT FOR LAW REFORM: 1640-1660, at 127 (1970). 
By Ryder's day, however, this complaint was largely rhetorical. A revolution in criminal sanctions, whose finishing touches Parliament had enacted in 1717 , largely eliminated the death penalty from the punishment of grand larceny and replaced it with a species of penal servitude: transportation to the American colonies for indentured service for a term of seven years. ${ }^{141}$ This fundamental change occurred in a manner characteristic of our law. A medieval institution, here the so-called benefit of clergy, underwent a long series of interstitial changes that ultimately transformed its function. The pattern of criminal charges, verdicts, and sentences in the Old Bailey in the middle of the eighteenth century can only be understood against the background of this great development.

\section{A. Benefit of Clergy}

In its inception "[t]he privilege known to later generations as benefit of clergy was a concession made by royal law to the Church in the aftermath of the Becket controversy."142 The ecclesiastical representative who attended medieval trials controlled the privilege. If he endorsed an accused's claim to be a cleric, the royal court released the accused to the ecclesiastical court.

By the end of the middle ages the royal courts had secularized $^{143}$ the privilege by transferring to themselves the responsibility for determining a criminal accused's claim of ecclesiastical status. The judges took literacy as the test of this status, with the result that the privilege was extended to all who could read. ${ }^{144}$ Because this had the effect of immunizing the literate from the law of felony, a statute of 1489 provided that a person could claim the privilege only once. ${ }^{145}$ In order to make this restriction effective in an era before centralized criminal record keeping, it was arranged that the person so released should be branded on his thumb, thus to bear upon himself some evidence of his future disqualification to

1614 Geo., ch. 11, $\S 1$ (1717). On the origins of the sanction of transportation and its development into the eighteenth century, see A.E. SMrTh, Colonists nN BondaGE: White SERVITUde AND CoNvict LABOR IN AMgrica: 1607-1776 (1947). On the parallel between transportation in England and the European systems of penal servitude, see Langbein, The Historical Origins of the Sanction of Imprisonment for Serious Crime, 5 J. LEGaL STUD. 35 (1976), substantially reproduced as chapter two of J.H. LANGBEIN, TORTURE AND THE LAW OP Proof: Europe and ENGland in the ANCIEN REgme 27-44 (1977).

142 Baker, Introduction to 2 Thr Reports of SIR John Sprimañ 327 (J.H. Baker ed. 1978) (94 Selden Soc'y) [hereafter cited as Baker, Spelman Introduction].

112 Id.

144 Id. at 328-31.

14s 4 Hen. 7, ch. 13 (1489). 
plead clergy. ${ }^{148}$ Another important change that occurred in later medieval judicial practice was that the claim to benefit of clergy came to be entertained only after conviction; the privilege thereafter operated in arrest of sentence rather than trial. In 1576 benefit of clergy was further secularized when legislation wholly eliminated the role of the ecclesiastical courts. The same statute gave the court the discretion to order the accused imprisoned for as much as one year before his release, but that provision was used infrequently. Thereafter, when the royal court granted the privilege, it released the accused-either outright or following a term of confinement. ${ }^{147}$

By the sixteenth century, therefore, benefit of clergy had lost all semblance of its original function, which had been to preserve ecclesiastical jurisdiction over ecclesiastical persons. Benefit of clergy had become a rubric by which the nonecclesiastical courts mitigated the law of felony for nonecclesiastical persons. For those who qualified (which is to say literate males, females never having been eligible for holy orders), benefit of clergy made capital punishment into a sanction for second offenders. The statute book granted literate males the privilege to commit one felony without fear of the death penalty.

This two-time-loser rule could scarcely be tolerated for the more serious felonies. Hence, even as it was being developed, it was subjected to exclusions that drastically limited its application outside the sphere of larceny. The medieval common law had refused to extend benefit of clergy to certain heinous offenses-treason, highway robbery, arson of a house. In 1512 legislation made both murder and robbery nonclergyable when committed in a church or dwelling house or on the highway. Later in the century the privilege was removed from other major offenses, including all murder, piracy, burglary, highway robbery, church robbery, rape, abduction with intent to marry, horsetheft, and stealing privately from the person (pickpocketing) to an amount above one shilling. ${ }^{148}$ Thus, by the beginning of the seven-

168 See Baker, Criminal Courts and Procedure at Common Law 1550-1800, in CRIME IN ENGLAND: 1550-1800, at 15, 41-42 (J.S. Cockburn ed. 1977) [collection hereafter cited as CockBurn Essays]: "The burned thumb was not, however, a legal record; it warned the court officers to counterplead the prayer of clergy by producing the record of the previous conviction. So tedious was this procedure that some convicts doubtless had their clergy a second time."

${ }_{167}$ See 18 Eliz., ch. 7, §§ 2-3 (1576), discussed in 4 W. BLAckstonE, supra note 29, at 362; 1 J.F. Stephen, A History of the Criminal Law op England 462 (1883).

${ }^{248} 1$ J.F. STEPHEN, supra note 147, at 464-65. 
teenth century the major crimes of violence and the most detested property crimes had been made capital again even for literate male first offenders, while routine grand larceny remained clergyable and hence noncapital for persons entitled to claim the privilege.

Once benefit of clergy assumed its ultimate character as a device primarily used to mitigate capital punishment for larceny, the original restrictions to persons male and literate became ever more archaic and irrational. An act of 1624 extended the equivalent privilege to women convicted of larceny under the value of ten shillings. ${ }^{149}$ Further legislation in the 1690s extended benefit of clergy to women equally with men for all clergyable offenses. ${ }^{100}$ The literacy requirement, having been long fictionalized in its administration, ${ }^{151}$ was abrogated by statute in $1706 .{ }^{182}$ Thenceforth, "[a]ll felonies were either clergyable or not. Everyone charged with a clergyable felony was entitled to benefit of clergy for his first offense ...."15s The final reform that settled the system of benefit of clergy for the rest of the eighteenth century was enacted a decade later. A statute of 1717 provided that the trial court would have the power to sentence a convict who was allowed clergy to seven years' transportation, rather than release him outright with a branded thumb. ${ }^{154}$

The result of these centuries of twists and turns can be stated simply: Transportation replaced death as the sanction for grand larceny and other clergyable felonies committed by first offenders. Benefit of clergy drained much of the blood from a system of criminal sanctions that remained nominally based upon capital punishment. As Blackstone explained, "by the merciful extensions of the benefit of clergy by our modern statute law, a person who commits a simple larceny to the value of thirteen pence or thirteen hundred pounds, though guilty of a capital offense, shall be excused the pains of death: but this is only for the first offense." "1ss

The words "capital" and "death" became misnomers; for clergyable offenses they were legal terms of art for transportation. The common understanding of this point can be glimpsed from the evidence given in the course of one of the trials at Ryder's second

140 21 Jac., ch. 6 (1624).

1so 3 W. \& M., ch. 9, §§ 6-7 (1691); 4 W. \& M., ch. 24, § 13 (1692).

161 For discussion of the tradition of the "neck verse," see Baker, Spelman Introduction, supra note 142, at 329-30; J.S. CockBURN, supra note 92, at 128.

162 Statute of 6 Anne, ch. $9, \S 4$ (1706).

16s 1 J.F. STBPHEN, supra note 147, at 463.

1844 Geo., ch. 11, $\$ 1$ (1717).

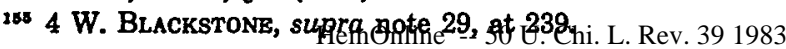


Old Bailey sessions in April 1755. A shopkeeper caught an employee stealing tobacco, seemingly for resale, and testified that he asked him where he had been fencing it. The culprit replied that "if I would not transport him he would tell me."156

The death penalty still had a robust future ahead of it in English law for felonies that had been made nonclergyable by statute. Indeed, the expansion of benefit of clergy was a major cause of the transformation of the criminal law from a common law field into a field ever more governed by statute. Once benefit of clergy had eliminated the death penalty as the sanction for common law felonies, statute alone could restore or extend the death penalty by designating an offense as nonclergyable. Despite the growth of nonclergyable offenses, however, English law never disturbed the fundamental alteration that had been achieved through the expansion of benefit of clergy: Grand larceny, the most prevalent of felonies, was effectively reduced to a noncapital offense, unless it fell within some category that statute rendered nonclergyable.

The statutes that withdrew clergy from particular forms of larceny were of two general types, which we may label the "aggravating circumstances" and "clergyable amount" varieties. For example, a theft otherwise "simple" and clergyable became nonclergyable if charged by the victim (or other prosecutor) and found by the jury to have been committed burglariously, that is, by the aggravated means of breaking and entering at night. ${ }^{157}$ Of the "clergyable amount" statutes, two were immensely important in the routine business of the mid-eighteenth-century Old Bailey. An act of 1699 withdrew clergy from shoptheft of goods to the value of five shillings or more; ${ }^{158}$ an act of 1713 withdrew clergy from thefts of goods to the value of forty shillings or more committed in dwelling houses. ${ }^{159}$ Since most thefts would have occurred in shops and homes, and many would have extended to property of such values, these two acts would have inflicted a heavy toll of capital punishment if fully enforced. In practice, these and the other statutes that withdrew clergy from crimes of larceny on condition of circumstance or amount were invoked relatively sparingly. The victim could and often did "undercharge" by declining to charge the cir-

186 John Dennis, OBSP (Apr. 1755, \#195), at 182:

167 On the law of burglary see 1 W. Hawkins, A Treatise of the Pleas of the Crown, ch. 38, at 101-05 (London 1716-1721) (2 vols.). The exclusion of burglary from benefit of clergy extends back to 1 Edw. 6, ch. 12, § 9 (1547); see 2 W. Hawkins, supra, ch. 33, at 357.

188 10 Will. 3, ch. 12, \& 1 (1699).

18812 Anne, ch. 7, § 1 (1713). 
cumstances or amount that made the offense nonclergyable. ${ }^{160}$ Further, when the victim charged the offense fully, the jury could convict of a lesser and clergyable offense. The jury could "downcharge" by convicting of simple larceny while refusing to find that the theft occurred in the shop or dwelling house or that it had been committed by means of breaking and entering; or the jury could "downvalue" by finding the worth of the stolen goods to be below the respective five- and forty-shilling ceilings. The recurrent verdicts of four shillings ten pence and thirty-nine shillings in Old Bailey trials are telltale signs of this process, bringing the offenses within the benefit of clergy in order that the offenders be transported rather than executed.

Only a small fraction of eighteenth-century criminal trials were genuinely contested inquiries into guilt or innocence. In most cases the accused had been caught in the act or otherwise possessed no credible defense. To the extent that trial had a function in such cases beyond formalizing the inevitable conclusion of guilt, it was to decide the sanction. These trials were sentencing proceedings. The main object of the defense was to present the jury with a view of the circumstances of the crime and the offender that would motivate it to return a verdict within the privilege of clergy, in order to reduce the sanction from death to transportation, or to lower the offense from grand to petty larceny, which ordinarily reduced the sanction from transportation to whipping. I shall return to this subject (under the heading of "partial verdicts") ${ }^{161}$ after outlining some main features of the Old Bailey caseload in the Ryder years.

\section{B. Offenses and Offenders}

1. Charges. At Ryder's four sessions in 1754-1756 the Old Bailey tried 171 cases comprising 179 offenses. ${ }^{162}$ In the following tabulation, offenses are described in nontechnical terms and listed in

100 This tendency continued long into the next century. See RgPORT FRoM the SBLbct Commttre to Consider of So Much of the Criminal Law as Retates to Capital PunishMENT IN Felonies 84 (London 1819) (8 Parliamentary Papers) [hereafter cited as 1819 REPORT].

101 See infra notes 199-209 and accompanying text.

162 Excluded from this number are a few cases that did not go to verdict at the particular sessions and were put off to another sessions. The OBSP almost never note these, but Ryder's notebook contains several entries concerning them.

In eight cases involving multiple defendants the court tried separate indictments for receiving stolen goods simultaneously with the related larceny cases, which accounts for the discrepancy between 171 trials and 179 offenses. 
rough order of gravity. In order to avoid double counting, the table records only the more serious offense in some cases in which an indictment charged more than one. For example, when someone was charged with burglary and theft, the table reports burglary, the nonclergyable offense.

\section{THE OFFENSES}

$\begin{array}{lr}\text { homicide } & 3 \\ \text { burglary, breaking and entering } & 7 \\ \text { highway robbery } & 4 \\ \text { livestock theft } & 6 \\ \text { pocketpicking } & 13 \\ \text { shoptheft } & 20 \\ \text { theft from lodgings, inns, pubs } & 15 \\ \text { domestic theft } & 10 \\ \text { theft from workplaces or employers } & 13 \\ \text { other theft, 40s or over } & 15 \\ \text { other theft, under 40s } & 53 \\ \text { receiving stolen goods } & 13 \\ \text { forging a will } & 1 \\ \text { aiding a jailbreak } & 1 \\ \text { assault and larceny } & 2 \\ \text { perjury and abuse of legal process } & 3\end{array}$

Although our 171-case sample is too small (as well as too confined in time and place) to be of value for many of the purposes that are important to scholars of historical crime statistics, it will help us to understand a number of features of the criminal procedure that was employed.

This Old Bailey caseload involved nothing but felony, excepting only the three cases of grave misdemeanor (perjury and abuse of legal process) and three of the thirteen pickpocketing cases in which the goods were valued at less than a shilling. Petty larceny was not tried at the Old Bailey, but at the London and Middlesex equivalents of quarter sessions. ${ }^{163}$ Old Bailey juries did, however, return petty larceny verdicts in grand larceny cases when they chose to downvalue goods to below one shilling, which is one of the forms of "partial verdict" discussed below. ${ }^{164}$ Few of the property offenses that were tried as felonies in our sample would rise to the level of grand larceny under the law of a modern Anglo-American jurisdiction. Virtually all of the cases in our Old Bailey sample 
would today be resolved without jury trial. Most would be plea bargained or otherwise "diverted" from trial; those tried would be mostly without jury-either on account of the jury waiver ("bench trial") system in the United States, or as a result of statutory changes in England that have remitted most small property offenses to trial by magistrates. ${ }^{165}$

2. Outcomes. The 179 offenses in our sample involve 204 accused, of whom eighty-four were acquitted, a figure that accords substantially with the acquittal rate of about one-third that John Beattie computed for Surrey assizes over the period 1736-1753. ${ }^{166}$ The OBSP do not throw much light on the factors that motivated acquittals; well over half the acquittals in our sample appear in the pamphlets as squib or short reports. Among the better reported acquittal cases, we see two patterns: Juries were reluctant to convict upon the testimony of a single witness or when (for whatever reason) the identification of the culprit was put in doubt.

Of the 120 convicts, twenty were sentenced to death, four to branding, ${ }^{167}$ and eighty-five to transportation. The remaining eleven were convicted of lesser offenses. Eight of these were persons charged with grand larceny but convicted of petty larceny as a result of jury downvaluing; the other three were convicted of misdemeanors and ordered imprisoned (two of them to be pilloried as well). Of the twenty sentenced to death, nine were actually executed and the remainder were pardoned, most on condition of transportation.

Although seventy-two of the convicts, or about thirty-five percent, were women, none of those sentenced to death was a woman. This tendency of the mid-eighteenth-century felony courts to have a far greater proportion of female clients than is customary in modern times, but to have them bunched toward the bottom end of the scale of serious crime, has also been observed by Beattie for Surrey. ${ }^{168}$

${ }^{16 s}$ See infra text accompanying notes $487-94$, for discussion of the eighteenth-century preference for jury trial.

${ }^{168}$ Beattie, Crime and the Courts in Surrey: 1736-1753, in CockBurn Essays, supra note 146 , at $155,175$.

${ }_{107}$ "By the eighteenth century the branding was done so perfunctorily in most cases that it became 'a nice piece of absurd pageantry' . . ." Baker, supra note 146, at 42 (quoting M. Foster, Crown LAw, supra note 48, at 372).

${ }_{18 B}$ Beattie, The Criminality of Women in Eighteenth-Century England, 8 J. Soc. Hist. 80, 95 (1975) (data from period 1663-1802).

Janssen's tabulation, discussed infra text accompanying notes 173-79 computes for a 23-mayoral-year period (1749-1771) that 20 of the 678 convicts executed were female. S. Janssen, This Sheet Contains Three Tables, from 1749 to 1771 (London 1772) (broadside; 


\section{Murder}

Anyone accustomed to the levels of felonious homicide characteristic of modern American cities, or even modern English and European cities, will be astonished to see how little murder appears to have occurred in what was then the largest city in the world, with a population approaching seven hundred thousand. ${ }^{168}$ At Ryder's four sessions three homicide cases were tried, all resulting in convictions for mere manslaughter, ${ }^{170}$ which at that time was punished by branding the convict on the thumb before releasing him. ${ }^{171}$ Certainly one and probably two of these cases grew out of accidents that today would not be prosecuted. The third was more problematic: George Venables returned home to find his wife in bed with their lodger, whom he killed in anger with a knife. ${ }^{172}$

The low level of culpable homicide evidenced in the Ryder sources appears not to have been a statistical fluke. According to data for the mayoral years 1749-1771, compiled and published in 1772 by Stephen Theodore Janssen (who had served as the Mayor of London in the main Ryder year, 1755), exactly eighty-one persons, or slightly less than four per year, had been convicted of murder for the whole of London and Middlesex during this twenty-three year period. ${ }^{17 s}$

Janssen's figure represents murder convictions only, and as the case of George Venables illustrates, the figure would have been higher but for some manslaughter verdicts that reflect excessive leniency. There may also have been outright acquittals that were unjustified, although homicide has not generally been an area known to have inspired much jury sympathy. Nevertheless, allowing for this missing component of lenient verdicts of manslaughter and acquittal, the true murder rate strikes us as remarkably low. ${ }^{174} \mathrm{We}$

Guildhall Library, London, shelfmark B'side 27.15). (The broadside is reprinted as a foldout appendix in the endpapers of John Howard, AN Account of the Principal LazaretTos in EUROPE (2d ed. London 1791) (1st ed. Warrington 1789).)

185 The population of greater London in 1750 is reckoned at 675,000 in Wrigley, A Simple Model of London's Importance in Changing English Society and Economy 1650-1750, PAst \& Present, July 1967, at 44, 44.

170 Richard Matthews, OBSP (Apr. 1755, \#164), at 152; Mary Smith, OBSP (Oct. 1755, \#389), at 340; Ryder Notebook, supra note 19, at 41; George Venables, OBSP (Apr./May 1756 , \#225), at 175.

171 See 4 W. Blackstone, supra note 29, at 193.

172 OBSP (Apr./May 1756, \#225), at 175. The Gentleman's Magazine noticed Venables' case and compared it favorably with the reported case of Rex v. Maddy, 1 Ventris 159, 86 Eng. Rep. 108 (C.P. 1671). 26 Gentleman's MaG. 203 (1756).

${ }^{273}$ S. Janssen, supra note 168.

174 See generally Beattie, The Pattern of Crime in England 1660-1800, PAST \& PRE- 
must bear in mind that while defects of the policing system may have allowed some culprits to go undetected, murder was not an offense that invited much discretionary nonprosecution, on account of the constraints of the coroner system. ${ }^{175}$ Nor was there any forum for murder cases in London and Middlesex other than the Old Bailey. ${ }^{176}$

These figures that evidence a low murder rate help bring into focus some material gathered by Radzinowicz for the first volume of his History. He noticed that in the literature produced by contemporary travellers from abroad, England's low murder rate was commonly mentioned. Indeed, "while agreeing that offenses against property were very common, all these observers also note the comparatively low incidence of the more serious crimes of violence."177

Ironically, the English of the 1750s did not see their murder rate in so favorable a light. Parliament enacted the Murder Act of 1752-properly titled "An Act for Better Preventing the Horrid Crime of Murder"-whose preamble recited that "the horrid Crime of Murder has of late been more frequently perpetrated than formerly, and particularly in and near the Metropolis."178 And indeed Janssen's table shows a spurt of murder convictions in the 1752 mayoral year: a total of ten as compared with annual totals for the three previous years of one, three, and one, respectively. ${ }^{178}$ The 1752 act purported to increase the sanction for murder by adding an extra dimension to the supposedly ultimate sanction of capital punishment. The statute directed that after being hanged the murderer's body should be turned over to surgeons for anatomization. Although the surgeons' need for bodies for teaching and experiment underlies this odd provision, there was nothing disingenuous about the idea that anatomization aggravated the

SENT, Feb. 1974, at 47, 60-61; Gurr, Historical Trends in Violent Crimes: A Critical Review of the Evidence, 3 CrIME \& Just. 295, 303-15 (1981); Sharpe, Domestic Homicide in Early Modern England, 24 Hist. J. 29 (1981).

175 See generally R.F. HunnisetT, Thb Mrdibval Corongr (1961); Hunnisett, Introduction to Wiltshire CoRonsrs' Buls: 1752-1796 (R.F. Hunnisett ed. 1981) (Wiltshire Rec. Soc'y).

136 See supra note 5. On the absence of plea bargaining or other diversion of felony matters from trial, see infra text accompanying note 491.

1771 L. RAdziNowicz, supra note 49, at 708-09. For Blackstone's bumptious comparativism, see 4 W. Blackstone, supra note 29 , at 18.

$17825 \mathrm{Geo} .2$, ch. $37, \S 1$ (1752). For refutation of the common supposition that Henry Fielding drafted or influenced this measure, see Amory, Henry Fielding and the Criminal Legislation of 1751-2, 50 PHLOLOGICAL Q. 175, 181-89 (1971).

17? S. Janssen, supra note 168. 
sanction of death. Peter Linebaugh has shown in a fascinating article that the statute was greatly detested, in part because it collided with popular belief in the resurrection of the body. ${ }^{180}$

The 1752 act also altered the sentencing routine of the trial court. Whereas the practice had been to sentence all offenders at the end of a sessions, the Murder Act stipulated that sentence, including the sanction of anatomization, "shall be pronounced in open Court immediately after the Conviction of such Murderer, and before the Court shall proceed to any further Business, ... in order to impress a just Horror in the Mind of the Offender, and on the minds of such as shall be present, of the heinous Crime of Murder."181 Dudley Ryder prefaced his Old Bailey notebook with a summary of the sentencing provisions of the 1752 act, which he wrote out for himself in advance of his first sessions in 1754, in case he found himself presiding at a murder conviction. Ryder knew that the prior practice of the Old Bailey had been for the Recorder of London to sentence all the convicts, including those tried before other judges, at the end of the sessions. Thus he noted as a "query" about the effect of the 1752 act "whether at O[ld] $B$ [ailey] the Judge that tries or the Recorder pronounces sentence immediately, for the Act don't say who shall pronounce it, and therefore probably the Recorder doing it in other cases should not do it in this."182 Ryder prepared himself with the form of words, lest he need it, that "[m]y brother Foster told me that the Judges had among themselves settled" for sentencing pursuant to the act:

You shall be led from hence to the prison from whence you came, and from thence on the [blank] day of [blank] to a place of execution, and then and there you shall be hanged by the neck until you shall be dead, and afterwards your body shall be dissected and anatomized; and the Lord have mercy upon your soul. ${ }^{183}$

Ryder never had occasion to fill in the blanks in this form at any of his Old Bailey sessions, but he did impose the sentence on assize at Chelmsford in August 1754 (in the case of Frances Cheek, con-

${ }^{180}$ Linebaugh, The Tyburn Riot Against the Surgeons, in Albion's Fatal Tree, supra note 21, at $65,102-15$. This remarkable essay is deeply disfigured by the ugly aspersions of class bias that it casts upon the authorities. Fortunately, these lapses do not mar the author's achievement in reconstructing "gallows superstitions," $i d$. at 110 , and folk attitudes toward death.

${ }_{181} 25$ Geo. 2, ch. $37, \S 3$ (1752).

182 Ryder Notebook, supra note 19, at 2.

18s Id. at 2-3. 
victed of infanticide, further discussed in Part VII of this article). ${ }^{184}$

\section{Larceny: Charging and Valuing}

Concentrating now on offenses against property, which constituted the characteristic component of the Old Bailey caseload, we find in our sources ample confirmation of the familiar truth that eighteenth-century criminal law was markedly more benign in its application than in its letter. Perhaps half the 200 persons accused of property crimes were at risk of the capital sanction when apprehended, in the sense that they could have been charged with a nonclergyable offense, yet only nine were executed. The accused were steadily winnowed from the capital cohort through the pretrial, trial, and post-verdict phases of the criminal procedure. Contemporaries understood and approved of this selectivity in enforcement (which did not become seriously controversial for another generation); they thought that it maximized the preventive value of deterrence without resulting in a bloodbath. ${ }^{185}$

The processes of mitigation that produced this discrepancy between threat and outcome operated at four stages of the criminal procedure:

(1) in the victim's decision whether and how to charge;

(2) in the judge's powers to influence the jury's verdict and to affect sentence;

(3) in the adjudicative work of the jury, when it convicted an offender of a lesser offense than he had committed or when it acquitted a culprit outright; and finally,

(4) in the crown's conduct of the clemency process.

It is the first and third of these stages, the charging and valuing work of the victims and the juries, that we wish to take up at this point as part of our discussion of the characterization of offenses in this Old Bailey sample.

1. Victims: Nonreporting and Undercharging. Even in modern legal systems, especially Continental ones, that try to confine the

184 See infra text accompanying notes $473-77$. Ryder adds in his diary:

It is the business of the judge to see that a surgeon is provided to take the body, and in present case the surgeon did agree to take this woman's body, but the clerk of assizes says it is left to him. And therefore I gave no particular direction about it, but understood from him that a particular surgeon had agreed to accept this woman's body to dissect.

Ryder Assize Diary, supra note 21, at 7.

${ }^{18 s}$ Radzinowicz's account of this large subject is still fundamentally sound. See $1 \mathrm{~L}$. RaDzINowicz, supra note 49 , at 23-25, 231-38, 410-15. 


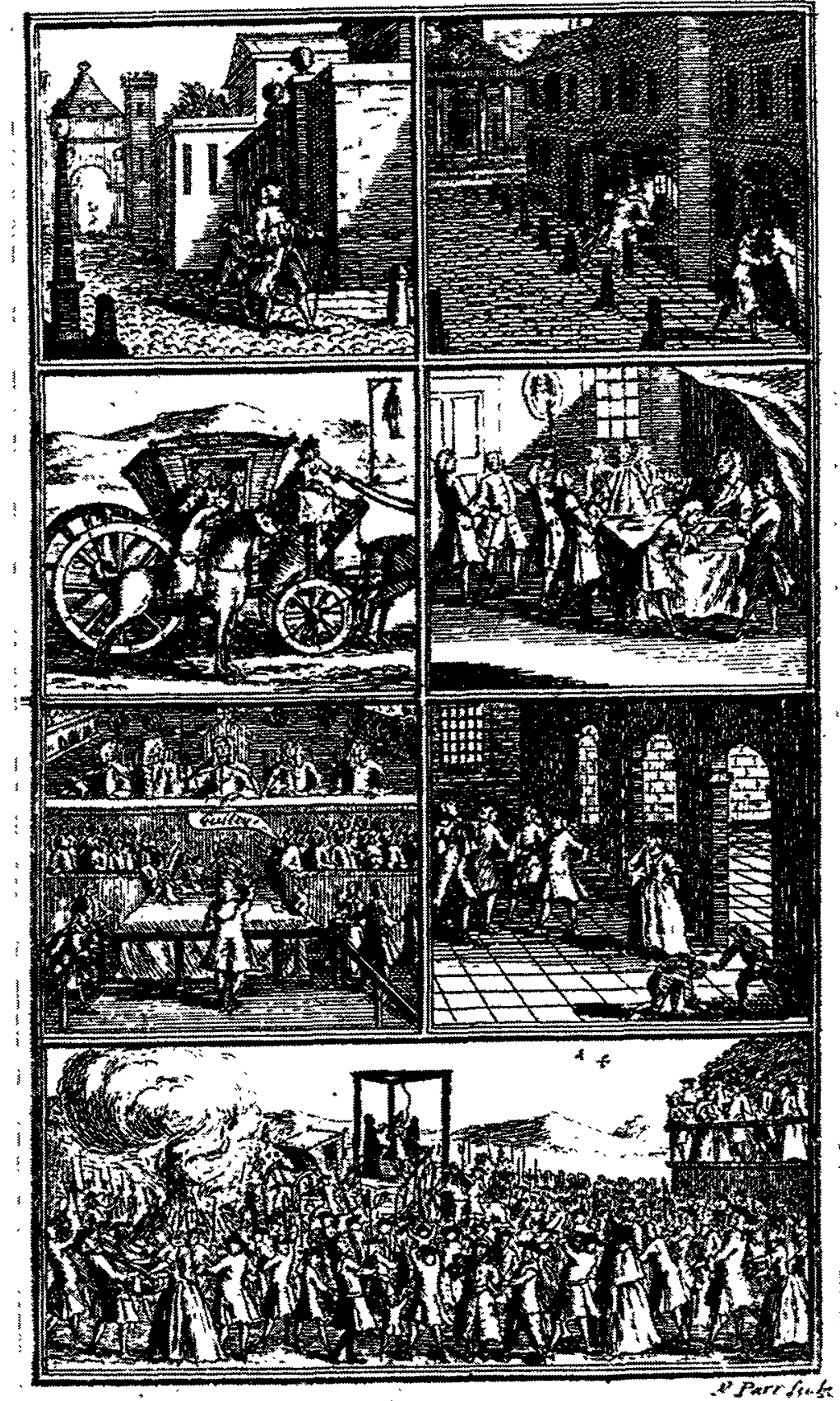

A Criminal Career (1742): pocketpicking leads to burglary, then highway robbery. Once apprehended, the culprit progresses through pretrial examination by the JP, conviction by the trial jury, post-trial detention, and execution. 
prosecutorial function to professional police and prosecutors, the victim of a property crime ordinarily commands a power of discretionary nonprosecution. The victim usually has complete control of whether to disclose the happening of the offense to the authorities, and thereafter his testimony and cooperation are essential to a successful prosecution. In the literature treating modern crime statistics, the problem of victims' nonreporting of offenses goes under the familiar label of the "dark figure."

We can be sure that in the eighteenth century, as in our own day, a good deal of crime went unprosecuted. In a well-known essay published in 1751, Henry Fielding, who was campaigning to increase the levels of prosecution, complains that potential prosecutors are either too forgiving or else too necessitous to take the time and incur the expense and nuisance of prosecuting. ${ }^{186}$ In one of the Old Bailey cases, Ryder records that the victim told the court how, when the pickpocket who stole from him was apprehended, he "begged of me not to prosecute him, which I refused."187 In another case an employer who caught a servant stealing silk testified that the thief "asked my pardon, and said if I would forgive him, he would never do so any more; he had served me the like before, so I would not forgive him, but took him up [that is, had him arrested and bound over for trial]."188

Sometimes the culprit had more to offer than mere entreaties. The evidence in several cases discloses that either the culprit or the victim suggested ending the matter short of prosecution by having the goods returned or a money payment made. Thus, James Welch, caught stealing socks from a shop, "was brought back into the shop [and he] offered to leave his coat for the damage done."189 The offer was declined and he was convicted. ${ }^{190}$ But in the case of Thomas Willes, accused of stealing household items from his lodging house, the jury acquitted when the prosecutor admitted that "I told him if he would get me my goods again, I would take no farther notice of it."191

186 H. Firlding, An Enquiry into the Causes of the Late Increase of Robbers 106 (London 1751) [hereafter cited as H. Firlding, Enquiry]. (Malvin Zirker has prepared a critical edition of the pamphlet for the Wesleyan/Oxford Press edition of the works of Fielding, which he has allowed me to consult in typescript. My citations, however, are to the first edition.)

${ }^{187}$ John Thompson, OBSP (Apr./May 1756, \#229), at 193 (squib report); Ryder Notebook, supra note 19 , at 59,60 .

18s Samuel Bentley, OBSP (Oct. 1755, \#367), at 328.

280 OBSP (Oct. 1755, \#382), at 338.

100 Id.

201 OBSP (Apr. 1755, \#178), at 162. 
Since our Old Bailey sample contains only cases that went to trial, attempts at composition had to have failed in order for our sources to evidence them. We have every reason to suppose that such tactics succeeded in other cases for which, as a result, we have no record.

Despite the nominally private character of prosecution in English law, there were forces at work that constrained discretionary nonprosecution. As a matter of statutory design, the pretrial binding-over system administered by the JPs purported to limit prosecutorial discretion by requiring the JP to bind over to trial "all such .... as do declare anything material to prove the ... Felony." 182 Yet this scheme assumed, in the language of the governing statute, a victim willing to "bring" the accusation to the attention of the JP. Nevertheless, there were aspects of the pretrial system that limited the discretion of a victim in not reporting to the JP. Whenever the victim needed the JP to help him recover stolen goods-for example, by issuing search or arrest warrants, or by granting immunity from prosecution in order to obtain accomplice disclosures-the JP had notice and was able to bind over. We shall see later in this article that these pretrial investigative steps are frequently evidenced in the Old Bailey cases in our sample.

Victims do appear to have had considerable discretion in deciding what offense to charge. For example, the theft of goods from a shop worth, say, six shillings might be variously characterized: (a) straightforwardly, as nonclergyable shoptheft above five shillings; (b) as simple, clergyable grand larceny, by valuing the goods below five shillings or by neglecting to charge that the theft occurred in the shop; or (c) as petty larceny, by valuing the goods below a shilling.

We do not have much of an understanding of how such choices were made. Our sources-trial narratives and the indictments upon which the accused were tried-pick up the cases after the charging decisions have been made. Sometimes, however, the trial evidence sheds enough light on the circumstances to enable us to see that a shoptheft or dwelling-house theft of nonclergyable amount occurred but was not so charged. ${ }^{103}$ Dudley Ryder's notebook ex-

1022 \& 3 Phil. \& M., ch. 10, § 1 (1555).

10s Following are three examples from the October 1754 sessions.

Elizabeth Poulson, OBSP (Oct. 1754, \#493), at 319, stole silver and linen worth more than 40 shillings from her former lodging house, but was indicted and convicted of simple theft. She was transported. The official record confirms the OBSP report that dwellinghouse theft was not charged. MxRO, OB/SB/1, Old Bailey Sessions Book (unpaginated, entries consecutive by date). 
plains in one of these cases, involving the theft of a silver tankard valued at six pounds from a house: "The jury found him Guilty generally, which is subject to clergy, [hence] only transportation, it not being charged to have been done in a dwelling house."194

It is hard to know in such cases what motivated the undercharging and who was really responsible for it. Evidence from a later time suggests that some victims insisted on undercharging because they were averse to the capital sanction. ${ }^{195}$ It also seems plausible that officials advised victims in some cases to undercharge on the ground that the jury would downcharge if the indictment attempted to charge fully. We know from a remark that Ryder recorded in his notebook that John Fielding, the "court JP"196 whose pretrial activities are particularly discussed in Part IV below, had a hand in advising the victim how to value the stolen goods in one of the cases in our sample. ${ }^{197} \mathrm{We}$ have evidence from the public records of a case in 1758 in which Fielding supervised an investigation through to charging. There had been an attempted highway robbery, the victim had been shot in the face, and an accomplice had identified Robert Nolan. Fielding ordered Nolan arrested, examined him, and "at the following Sessions [of the Old Bailey] I directed [the victim/prosecutor] to indict him on the Black Act for maliciously firing at him, as that Offense was Capital, and the attempting to rob only Transportation, esteeming the latter too slight a Punishment for so barbarous an Action; and ... the said Nolan was convicted."

Elizabeth Swift, OBSP (Oct. 1754, \#503), at 324, stole a silver watch valued at 40 shillings from the dwelling house of a soldier. Only simple theft was charged and she was convicted and transported. Accord $\mathrm{MxRO}, \mathrm{OB} / \mathrm{SB} / 1$, Old Bailey Sessions Book (unpaginated, entries consecutive by date).

James Barry, OBSP (Oct. 1754, \#513), at 338; Ryder Notebook, supra note 19, at 12 , noted infra text accompanying note 194 , stole a silver tankard valued at six pounds from his lodgings. The indictment charged the theft but omitted mention of the dwelling house, and the jury convicted. He was transported, OBSP (Oct. 1754), at 341. Accord CLRO, Sessions Minute Book (unpaginated, entries consecutive by date).

194 Ryder Notebook, supra note 19, at 13. Compare James Barry, OBSP (Oct. 1754, \#513), at 338 .

1831819 REPORT, supra note 160 , at $83,84,111$.

196 See infra notes 224-25 and accompanying text.

197 In the case of Thomas Rolf, OBSP (Oct. 1754, \#504), at 326; Ryder Notebook, supra note 19, at 18, John Fielding advised the prosecutrix on charging. She testified: "He said, 'do it rather under than over,' and therefore I swore to 5s., but I believe there might [have been] $8 \mathrm{s.} 6$ or more in my pocket" at the time of the robbery. Ryder Notebook, supra note 19, at 20. The role of John Fielding in the pretrial process is discussed below in Part IV. Regarding indictment drafting, see infra note 466.

183 PRO, T 1/383/75 ("Mr. Fielding's report upon the Petition of the constables of St. George's Parish," Nov. 18, 1758). 
2. Juries: Partial Verdicts. In thirty-nine of our 171 cases, involving forty-four accused, the jury returned what we call (following Beattie) a "partial verdict."198 The jury convicted the accused, but only in part; the jury convicted him of a less serious offense than the indictment charged, either by downcharging or by downvaluing the goods. These cases include the three homicides, where the respective juries came close to acquitting by downcharging murder indictments to manslaughter, reducing the sanction from death to branding on the thumb. Of the thirty-six property crimes, the partial verdicts were returned as follows:

(a) Eight persons charged with the capital offense of picking pockets $^{200}$ to the value of one shilling or more were convicted of the offense to the value of less than a shilling, hence petty larceny. All eight were sentenced to transportation.

(b) In three cases, persons accused of the capital crime of burglary were convicted of simple grand larceny and sentenced to transportation.

(c) In six cases persons indicted of the capital crime of shoptheft of goods valued at five shillings or more were convicted of lesser offenses. The juries downcharged below five shillings in four of the cases and found the culprits guilty of theft but not in the shop in the other two. Transportation was imposed in all the cases.

(d) In two cases involving theft from vessels above the clergyable sums, ${ }^{201}$ the juries downvalued and the accused were transported.

(e) In seven cases in which theft from dwelling houses over forty shillings had been charged, juries returned partial verdicts. In six the goods were downvalued, and in the seventh the offense was found not to have occurred in the dwelling house.

(f) In ten cases in which simple or clergyable grand larceny was charged, for which transportation was the severest punishment, juries reduced the value of the goods below a shilling and convicted of petty larceny. In eight of these cases the judge duly sentenced the convict to whipping, which was the customary sanction for serious misdemeanors. In the other two cases he exercised his power under the act of $\mathbf{1 7 1 7}$ to sentence a convict to transpor-

190 Beattie, supra note 166 , at 170.

2008 Eliz., ch. 4, § 1 (1566). See generally 1 W. Hawkins, supra note 157, ch. 35, at 9798.

201 The relevant statute is discussed supra note 79. 
tation for petty larceny, ${ }^{202}$ which largely defeated the purpose of the jury's downvaluing. ${ }^{203}$

Partial verdicts did not occur randomly across the various types of offenses. Rather, juries distinguished, first, according to the seriousness of the offense, and second, according to the conduct and character of the accused in a particular case. Some offenses were seldom or never the subject of partial verdicts, in others partial verdicts were routine, but in most the matter was more circumstantial.

Thus, in our sample, partial verdicts were not returned in any of the cases of livestock theft and highway robbery. Livestock theft was peculiar in that the offense was defined in a way that did not lend itself to a viable form of downcharging-the accused either stole the horse (or other beast) or not, and the governing statute did not further condition the capital sanction on the value of the animal or on any aggravating circumstance that the jury could manipulate in a partial verdict. ${ }^{204}$ Highway robbery could be downcharged-a jury could convict of theft not on the highway-but this did not happen much and not at all in our sample.

By contrast, we find the juries all but invariably downvaluing in pickpocket cases that were charged capitally (at a shilling or above). There were nine such cases in the four Ryder sessions. The juries downvalued below a shilling in eight but convicted capitally in the last. ${ }^{205}$

Most of the major property crimes fell between these extremes of offenses routinely subjected to partial verdicts and offenses never so treated. The quality of the evidence in the individual case became more important than the type of offense. The juries were lenient in dealing with persons indicted of shoptheft and theft

102 See Beattie, supra note 166 , at 171-72, regarding comparable Surrey practice.

${ }^{303}$ I am not able to deduce what factors motivated the judges to use their power to prefer transportation in these circumstances. In one of our two cases in which the OBSP report such outcomes, the official record corroborates the report. John Ingal, a bookseller's errand boy, defaulted in service and sold one of his master's books to a pawnbroker, OBSP (Oct. 1755, \#384), at 339, sentence noted id. at 362; accord CLRO, Sessions Minute Book (unpaginated, entries consecutive by date). The other case is Elizabeth Upton, OBSP (Oct. $1754, \# 506$ ), at 331 , sentence noted id. at 341 .

${ }^{204}$ E.g., 14 Geo. 2, ch. 6 (1741).

208 In the case that resulted in the capital verdict, Thomas James, OBSP (Oct. 1754, \#481), at 311; Ryder Notebook, supra note 19, at 7, the executive commuted the sentence to transportation. See S. Janssen, supra note 168. In addition to the nine cases mentioned in text in which pickpocketing was charged above a shilling, there was another, charged above a shilling, in which the accused was acquitted, and three others, resulting in convictions, in which the goods were charged below a shilling so that the capital sanction could not come into question. 
from dwelling houses above the capital sums. The only cases not downcharged or downvalued were those in which the evidence indicated the offenders were professionals or gang members. ${ }^{206}$ The juries were quite unashamed about returning partial verdicts even in situations involving thefts of money, in which downvaluing became transparent fiction. We noticed in another connection the case of John Taplin, indicted for stealing twenty-one guineas in money and a watch. The jurors valued this loot at thirty-nine shillings, and with the active connivance of Dudley Ryder, who recorded that they did it "after I told them that 40 s. was necessary to make him guilty of felony that was without benefit of clergy."207 Favorable evidence also motivated the juries fairly frequently to downvalue from grand to petty larceny in order to turn transportation into whipping, especially when the goods were of relatively small amount or when the accused was a married woman or a family man. The jurors took a harsher attitude towards burglary and breaking and entering, being more reluctant to prevent the capital sanction from being imposed.

Our sample is too small and our sources too recondite to throw much light on the workings of the partial verdict system. Even the mechanics are sometimes puzzling-why did some of the shoptheft and dwelling-house cases in the October 1755 sessions get downcharged (for example, guilty of the theft, but not in the shop), ${ }^{208}$ whereas at the other three sessions the partial verdicts took the form of downvaluing the goods? Our glimpse of Ryder's involvement in the case of John Taplin is exceptional; we do not in general have evidence about how the patterns and conventions of the partial verdict system were formed, influenced, and transmitted. We can say with some confidence (1) that partial verdicts were quantitatively important, comprising in our sample one-third of the guilty verdicts returned; ${ }^{209}(2)$ that they were principled, reflecting the severity of the crime and the circumstances of the of-

${ }^{208}$ E.g., the prosecutions by and of Charles Cane, discussed infra text accompanying notes 328-53.

${ }^{207}$ See supra note 71 and accompanying text.

${ }^{208}$ Abraham Davis \& David Davis, OBSP (Oct. 1755, \#390-91), at 349; Francis Burton, OBSP (Oct. 1755, \# 379), at 336; Alexander Murdock, OBSP (Oct. 1755, \# 377), at 333. The official record confirms that in all three cases verdicts of simple felony were returned, while verdicts of not guilty were given to the aggravated counts of theft from a warehouse, theft from a dwelling house, and shoptheft, respectively. MxRO, OB/SB/1, Old Bailey Sessions Book (unpaginated, entries consecutive by date).

${ }^{208}$ For property crimes tried in the years $1736-1753$ in Surrey, Beattie finds partial verdicts in about 30 percent of the capital cases and in 20 percent of the noncapital cases. Beattie, supra note 166, at 177. 
fender; and (3) that they added the dimension of sentencing proceeding to eighteenth-century jury trial. The jury not only decided guilt, but it chose the sanction through its manipulation of the partial verdict. Since guilt was typically although not inevitably a forgone conclusion in many (perhaps most) cases, sentence is what was at stake when these cases were "contested."

\section{Pretrial: The Fieldings and the Sitting Alderman}

The cases that we see brought to trial at the Old Bailey in Dudley Ryder's sessions were the product of a pretrial process in which steps had been taken to gather and sift evidence for trial. The pretrial procedures of this period are perhaps even less understood than the trial procedures. Because our trial sources supply some uncommon insight into the way evidence was assembled in the pretrial phase, we propose to devote some attention to the subject here. Nevertheless, it must be squarely acknowledged that the Ryder sources are not rich enough to serve as the basis for the large and systematic study of eighteenth-century pretrial procedure that is still so needed.

We have long been accustomed to say that English criminal procedure operated into the nineteenth century without either professional police or professional prosecution, and there is an important sense in which that is true. Sir Robert Peel's Metropolitan Police Act of $1829^{210}$ founded the "bobbies"; the Director of Public Prosecutions came into existence for a limited sphere of serious crime in 1879, after a remarkable political struggle. ${ }^{211}$ These and related developments ${ }^{212}$ radically increased the levels of official participation in and control of the processes of detection, investigation, charging, and prosecution.

Nevertheless, it would be quite inaccurate to view the procedure of earlier times as a system of strictly private prosecution. Although the private accuser (virtually always the victim, apart from homicide) was called the prosecutor and played an essential role in most prosecutions, he had official support. Some of the support mechanisms were of considerable antiquity. For cases of

21010 Geo. 4, ch. 45 (1829); see generally T.A. Critchiey, A History of Police in England and Wales 47-57 (rev. ed. 1978).

211 42 \& 43 Vict., ch. 22 (1879); see generally Kurland \& Waters, Public Prosecution in England, 1854-79: An Essay in English Legislative History, 1959 Duks L.J. 473.

21s Especially the reorganization and professionalization of the pretrial process associated with Sir John Jervis' Acts. See generally Freestone \& Richardson, The Making of English Criminal Law: Sir John Jervis and His Acts, 1980 CRm. L. Rzv. 5. 
homicide, where the victim was by definition unavailable to prosecute, the surviving kin had been afforced since the Middle Ages through the coroner system, which achieved a form of supplementary public prosecution. ${ }^{213}$

For the property crimes that were the main component of felony jurisdiction, victims could call upon the help of constables and JPs. The constable was an ordinary citizen serving a term as the law enforcement officer of his locality. ${ }^{214}$ Within the city of London the constables were reinforced with additional peace officers, the watchmen, who were compensated from the proceeds of a tax on each ward. ${ }^{215}$ Although a constable had some power to act on his own motion or on citizen complaint, including the power to arrest at the scene of a felony or in hot pursuit, in general he was subordinated to the direction of a magistrate, the justice of the peace (JP).

The JP was also an amateur, a citizen rendering part-time and largely uncompensated service in law enforcement and other matters of local government. He was a man of high social status, typically gentry, and he served at the pleasure of the crown, usually for many years. The JP's office had two main sides. At least from the sixteenth century the JP was the principal pretrial officer who investigated cases of serious crime on citizen complaint for trial at the assizes (or, in London, at the Old Bailey). The JP's other role was adjudicative and legislative. He was empowered, usually on condition that he be joined by a minimum number of his fellow JPs for the county (a number that varied with the function), to adjudicate in a variety of matters that we would today regard as misdemeanor, local administration, and economic regulation. The main adjudicative forum was the court of quarter sessions, generally composed of all the JPs of the county. The JPs also sat in smaller panels that met more frequently for the minutiae of licensing orders and petty offenses. ${ }^{216}$

In the present study we are concerned with the JP's role as a pretrial officer helping to generate evidence for felony trial. This responsibilty had its statutory foundation in an act of 1555, the

213 See generally R.F. HUNNISETT, supra note 175.

234 See generally $1 \mathrm{~S}$. WeBb \& B. WeBb, English Local Government: The Parish and THE CounTy 26-29, 489-502 (1906).

216 Corporation History, supra note 28, at 95-96. For detail, see the scheme set forth in the statute of $10 \mathrm{Geo} .2$, ch. 22 (1737) ("An Act for better regulating the Nightly Watch ... within the City of London . . . .").

236 See generally 1 S. WEBB \& B. WEBB, supra note 214, at 294-304, 319-446. 
Marian committal statute. ${ }^{217}$ The statute authorized the JP to whom a felony suspect was brought to examine the accused and the accusers, to reduce these examinations to writing for the trial court, and to bind over to trial both the accused and the "material" witnesses against him. The statute did not by terms require the JP to investigate a case more widely, for example to search out witnesses who did not volunteer, although such steps were implicit in the procedure and were widely taken. ${ }^{218}$ The JPs issued search and arrest warrants, usually for execution both by constables and by private complainants.

This peculiar system of having prominent community figures serve as part-time amateur detectives and pretrial committal officers was designed, ${ }^{219}$ if that is the word, for provincial conditions. It presupposed a relatively light caseload of serious crime ${ }^{220}$ and a set of JPs whose self-interest in keeping local order and reinforcing their own stature in the community would provide sufficient incentive to serve. There was always a problem in getting enough such men to take an active role. The problem worsened appreciably when urbanization occurred in areas with a thinly populated gentry. ${ }^{221}$ The prospect of a greatly augmented caseload in circumstances of altered and less deferential social relations was not likely to attract men of the preferred sort for service as JPs.

In metropolitan London, especially in the rapidly growing environs of Middlesex, this problem was acute, and it led to a pair of adaptations, the "trading justice" and the "court JP." The term "trading justice" was a pejorative and has remained so, but as no neutral expression developed we are stuck with it. A trading justice

2172 \& 3 Phil. \& M., ch. 10 (1555).

218 See the evidence assembled in J. LANGBEIN, supra note 120 , at 34-53, 77-97.

210 On the origins of the system, see $i d$. at 5-20.

${ }^{220}$ For example, in the recently published justicing notebook of a Wiltshire JP that covers a five-year period from 1744 to 1749 , hundreds of petty matters are reported (misdemeanor, bastardy, licensing, binding over to keep the peace), but only two cases of pretrial examination for felony that reached trial at assizes. The Justicing Notrzook of WirlinM HuNr 1744-1749, at 61-62 (E. Crittall ed. 1982) (entry nos. 414, 416). In addition, there were a few theft cases that might have gone to felony trial at assizes but did not, on account of composition, see, e.g., id. at 38,71 (nos. 212,485 ), because the accused was fugitive, see, e.g., id. at 40 (no. 234), or because the charge could not be substantiated, see, e.g., id. at 42,63 (nos. 248, 428).

221 See, e.g., Styles, "Our Traitorous Money Makers": The Yorkshire Coiners and the Law, 1760-83, in An Ungovernable Prople: The English and Their Law in the SevenTEENTh AND EighteknTh Centuries 172, 207 (J. Brewer \& J. Styles eds. 1980); Styles, An Eighteenth-Century Magistrate as Detective: Samuel Lister of Little Horton, text accompanying note 8 (forthcoming in BRADFORD ANTIQUARY, 1982); $1 \mathrm{~S}$. WBBB \& B. WRBB, supra note 214 , at 321 . 
made justicing his trade. He earned his living from fees arising from the office. He was, therefore, someone of lower social standing than the landed gentry in the countryside who affected to disdain the opportunity for revenue and for whom the attraction of office was enhanced local social leadership. In raw urban areas, gentry were not obtainable and men of lesser rank and means had to be used.

Licensing was one recognized source of fees for trading justices; clerical services were another. Little of a JP's work as a pretrial examining and committal officer for felony could give rise to fees-at any rate legitimate fees. There was an odor of extortion and payoff in the reputation of the trading justice, and it is easy to imagine how a trade in unjustified committals and discharges could have been profitable, although it is scarcely evidenced..$^{222}$ The whole subject of the trading justice is virtually unresearched, and we are simply unable to say how much corruption there really was, especially in the pretrial process for cases of serious crime. Certainly, much of the contemporary hostility to the trading justice arose from upper-class resentment at the appearance of social inferiors in the commission of the peace. ${ }^{223}$

By allowing trading justices, the central authorities increased the number of urban JPs, and this expedient sufficed for many purposes. But for the side of the JP's office that was not remunerative, the job of pretrial investigation in felony, some further modification of the rural, provincial pattern was needed. In the City of London it took the form of the "sitting alderman" system, while in Middlesex it was the "court JP."

222 One instance, reported in the Gentleman's Magazine and said to have happened on May 11, 1733:

A Cause was tried in the Common Pleas at Westminster, between Mr. Freeman, a Plasterer, Plaintiff, and J-_ C___, Esq., a Justice of the Peace, Defendant, for extorting a Shilling from him for a Discharge, though there was no Warrant granted, nor was there a Clerk to pretend a Demand for the same. It was likewise proved to be his daily Practice to take Money for binding over, [and for] granting and discharging of Warrants, which the Judge observed was a great Abuse and contrary to Law. The Jury gave a Verdict for the Plaintiff and one Shilling Damage and Cost of Suit.

3 Gentleman's MaG. 266 (1733) (emphasis in original). See infra note 441 (final paragraph) for further discussion of fee abuses attributed to trading justices through their clerks.

${ }^{23 s}$ See 1 S. WEBB \& B. WeBB, supra note 214, at 326-27. A pamphleteer hostile to John Fielding labored to apply the epithet of trading justice to him. "I need not inform you, Sir John, that Middlesex Justice and Scoundrel are synonymous terms . . . . [W] esteem you the founder of a Rotation office, which begat you likewise the appelation of Trading Justice." Robert Holloway, The Rat-Trap: Dedicated to the RT. Hon. Lord Manstibld, Chief Justice of England; Addressed to Sir John Fielding 9, 12 (London 1773) (BL shelfmark 12330.cc.37). 


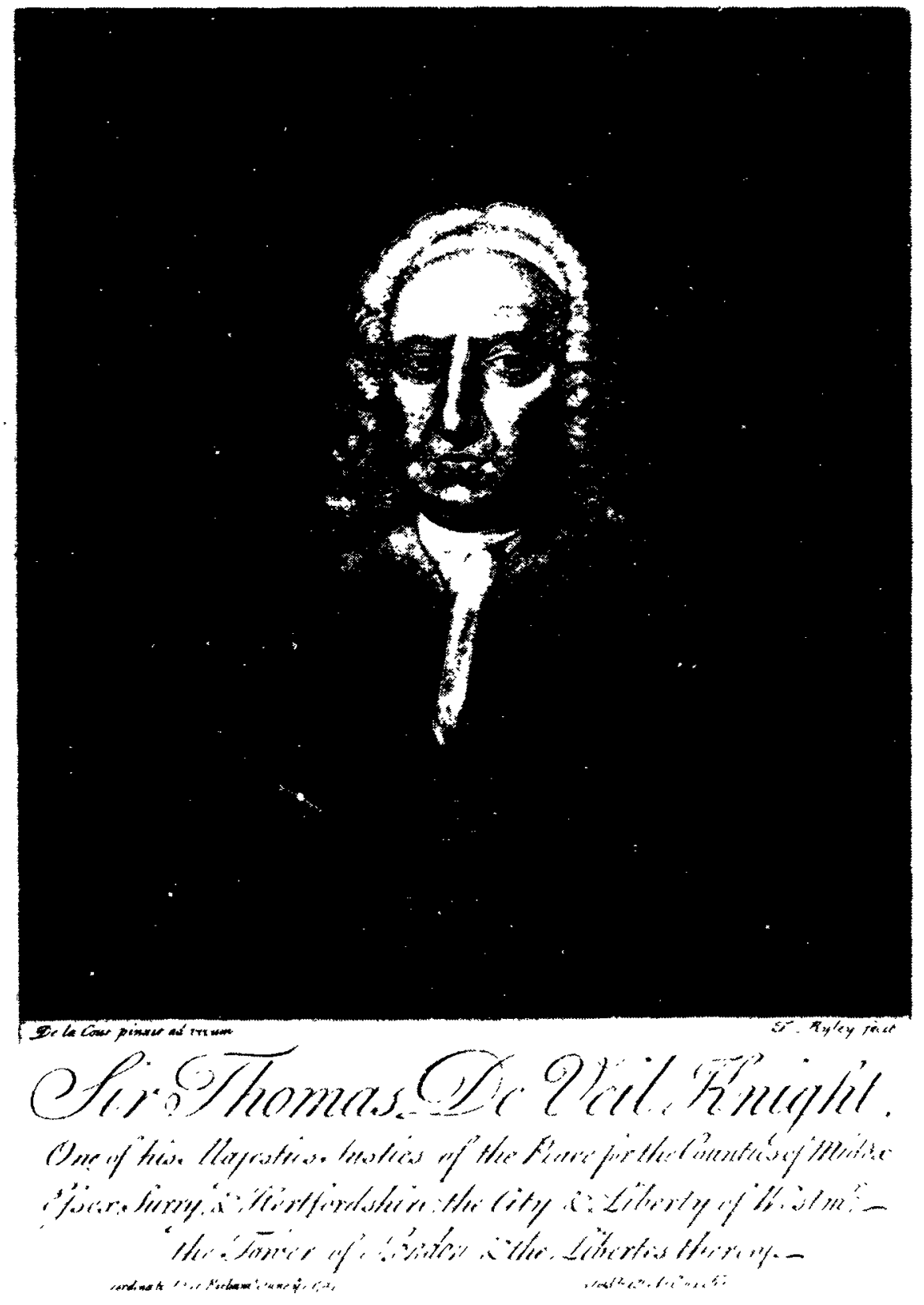


By the 1730 s, and perhaps earlier, ${ }^{224}$ the central government was taking a hand in strengthening local law enforcement in Middlesex (where the seat of government was located as well as the residences of most officials, parliamentarians, ambassadors, and so forth). Beginning at the latest with Sir Thomas de Veil, a former soldier who entered the Middlesex commission of the peace in 1729 , the government took to singling out one of the Middlesex JPs for special service in criminal investigation and prosecution. $\mathrm{He}$ received financial support, both in the way of compensation and in order to defray expenses. The person invested with this quasi-official status became known as the "court JP," "court" in this usage referring to the central government. De Veil served in this capacity until his death in 1746. The OBSP of his years afford frequent glimpses of his work as a pretrial examiner and committal officer, corroborating in a general way an anonymous but seemingly candid pamphlet biography, ${ }^{225}$ published posthumously, that is the main source of knowledge about de Veil's career.

\section{A. Henry Fielding's System}

De Veil was succeeded in 1748 by Henry Fielding, the novelist, whose Tom Jones appeared the following year. Fielding studied law and seems to have written a treatise on crown law, that is, criminal law, which probably existed in manuscript and was actually announced for publication in 1745 but never appeared. ${ }^{228}$ Fielding took over de Veil's clerk, Joshua Brogden, ${ }^{227}$ and he succeeded to de Veil's lease of the Bow Street residence owned by the

${ }^{224}$ An anonymous author claimed to trace the court JP system back through various supposed seventeenth-century incumbents and into Elizabethan times, but on insubstantial evidence, in Memolrs of the Life and Times of Str Thomas DeveIL 22-34 (London 1748) [hereafter cited as DE VEII Blography]. The Webbs repeat this tale. $1 \mathrm{~S}$. WeBB \& B. WeBB, supra note 214 , at $337-38$.

${ }^{228}$ DE VEIL BIOGRAPHY, supra note 224. In addition, there survives a short pamphlet written by de Veil, advising JPs on the conduct of their office, whose main concern is to warn them about their liability to suits for false imprisonment should they err in warrant, arrest, or binding over matters. T. DE VeI, Observations on the Practice of a Justice op the Peace: Intended for Such Gentlemen as Design to Act for Middlesex or WestminSTER (London 1747) (posthumous publication).

${ }^{226}$ Coley, Henry Fielding's "Lost" Law Book, 76 Mod. Language Notes 408 (1961); cf. Amory, A Preliminary Census of Henry Fielding's Legal Manuscripts, 62 Papers BrbloGRAPHICAL SoC'Y AM. 587, 595 (1968). (I owe these and several of the following references on the literature treating Henry Fielding to Malvin Zirker.)

${ }^{227}$ H. Fielding, The Journal of a Voyage to Lisbon (written 1754, published posthumously), reprinted in Jonathan WIID and The Journal of a Voyage to Lisbon 191, 194 n.1 (Dent-Dutton ed. 1932) [hereafter cited as H. Fididing, Lisbon Diary]. For earlier mention of Brogden, see supra note 122. 
Duke of Bedford (a prominent figure in the Whig ministry). ${ }^{228}$ Bow Street has been the scene of a magistrate's court ever since. ${ }^{229}$

Fielding left rather better evidence of his work as court JP than did de Veil, although we are far from having a clear picture of the office. ${ }^{230}$ Fielding was the proprietor of a newspaper, the Covent Garden Journal, ${ }^{231}$ which chronicled some of his work during its short life of eleven months in 1752, and he arranged to have his magisterial work noticed in other newspapers as well. ${ }^{232} \mathrm{He}$ wrote some reflections about his justicing career as he sailed off to die in Portugal in 1754. ${ }^{233}$ His brother John, who succeeded him as the court JP, left accounts describing some of Henry's conduct of the office. ${ }^{234}$

1. Investigation. Henry Fielding was a determined examiner, especially in cases involving gangs. In January 1752 the Covent Garden Journal tells of his spending "many hours" on a rape case $^{235}$ and, a few days later, sitting for twenty hours and then a further eight on a murder case. ${ }^{236}$ When dealing with the major property crimes, the "crown witness" system could be invoked, whereby Fielding granted immunity from prosecution to a culprit in exchange for his assistance in identifying, apprehending, and prosecuting his former accomplices. ${ }^{237}$ Fielding described the prac-

228 Battestin \& Battestin, Fielding, Bedford, and the Westminster Election of 1749, 11 EighteEnth-Century Stud. 143, 148-49 \& n.15 (1977-78). See id. at 150 on Bedford's role in placing Fielding in the office.

2303 L. Radzinowicz, supra note 49 , at 29 n.2.

${ }^{2 s 0}$ See generally Coley, Fielding's Two Appointments to the Magistracy, 63 Mod. PHIlology 144 (1965); B.M. Jones, Henry Firlding: Novelist and Magistrate 113-27 (1933).

${ }_{231}$ See supra note 122. Only literary and nonlegal materials appear in the two-volume publication of extracts from the newspaper titled The Covent Garden Journal (G. Jensen ed. 1915).

${ }^{232}$ Regarding Fielding's use of other newspapers, see Shepperson, Additions and Corrections to Facts about Fielding, 51 Mod. Philology 217, 220-24 (1954); G. Armitage, The History OF THE BOW STREET RUNNERS 1729-1829, at 51-52 (1932).

238 H. Fielding, Lisbon Diary, supra note 227.

2s4 J. Fielding, A Plan for Preventing Robberies within Twenty Miles of London (London 1755) [hereafter cited as J. Fielding, Plan]; J. Fizlding, AN Account of the ORIgin and Efrects of a Police Set on Foot gy His Grace the Duke of Newcastle in the Year 1753, upon a Plan Presented to His Grace by the late Henry Fiblding, Esq. (London 1758) [hereafter cited as J. Finuding, Account].

2ss CGJ, supra note 122, Jan. 25, 1752, at 2, col. 3.

${ }^{238}$ Id., Jan. 28, 1752, at 2, col. 2. At the end of his life, Fielding complained of the 16hour days that his clerk had to work serving Fielding's magistracy. H. FikLding, LisBon DIARY, supra note 227 , at 194 .

287 The crown witness system is discussed infra text accompanying notes 322-421. For instances of accomplice-aided investigations in the Covent Garden Journal reports, see CGJ, supra note 122, June 16, 1752, at 2, col. 3; id., June 6, 1752, at 2, col. 3; id., May 16,

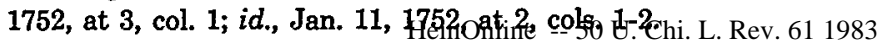




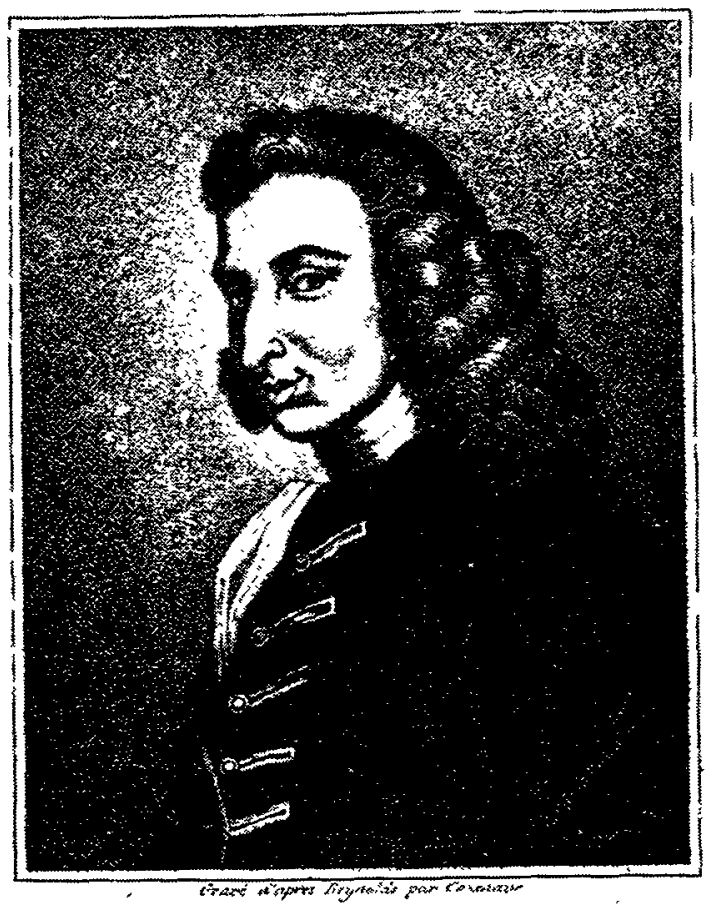

Henry Fielding, after a drawing by Hogarth

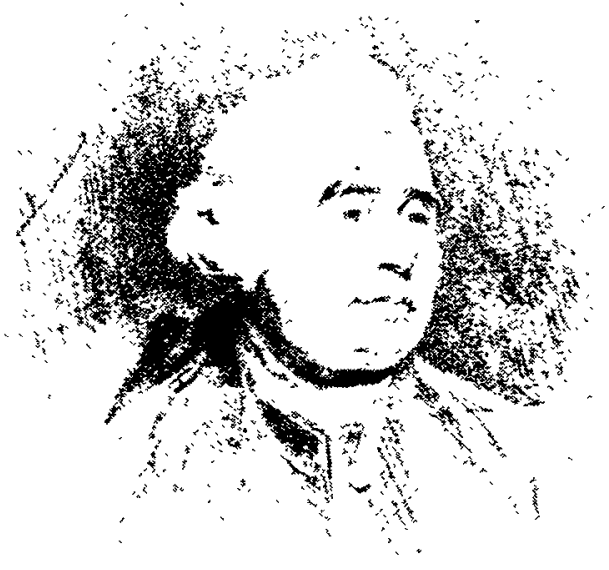

Saunders Welch 
tice in his tract of 1751, An Enquiry into the Causes of the Late Increase of Robbers ${ }^{238}$ (hereafter called the Enquiry): "In Street Robberies the Difficulty of convicting a Criminal is extremely great. The Method of discovering these is generally by means of one of the Gang, who being taken up [that is, arrested], perhaps for some other Offense, and, thinking himself in Danger of Punishment, chooses to make his Peace at the Expense of his Companions." ${ }^{239}$ (We devote Part V of this article to the crown witness system.)

Fielding's investigations had contrasting tendencies. On the one hand, he was trying to cast a wider net by following up on leads and by encouraging greater reporting of crimes and missing property; he was gathering evidence for trial at the Old Bailey. This side of the job anticipated what became the Criminal Investigation Division of Scotland Yard. On the other hand, Fielding was also sifting and discharging cases that would not stand up if sent on for trial, and in this respect he was the forerunner of the judicialized pretrial committal officer of the nineteenth century. Some of Fielding's discharges took the form of having the victim/ prosecutor withdraw the charge, ${ }^{240}$ which happily avoided the delicate question of whether JPs had the legal authority to dismiss felony charges, however ill founded. ${ }^{241}$

2. The Clearing House. Fielding instituted a number of mea-

${ }^{238}$ H. FIELDING, ENQUIRY, supra note 186.

230 Id. at 111.

240 For instances of withdrawal of charges in the Covent Garden Journal reports, see CGJ, supra note 122, Apr. 18, 1752, at 2, col. 3; id., Feb. 8, 1752; at 2, col. 2. For instances of dismissals, see id., Apr. 4, 1752, at 2, col. 3; id., Feb. 1, 1752, at 2, col. 2; id., Jan. 28, 1752, at 2 , col. 2.

${ }^{241}$ In the February 25 issue of the Journal, Fielding expressed his irritation:

By the Law of England, as it now stands, if a Larceny be absolutely committed, however slight the Suspicion be against the accused, the Justice of Peace is obliged in strictness to commit the Party; especially if he have not Sureties for his Appearance to answer the Charge.

Nor will the trifling Value of the Thing stolen, nor any Circumstance of Mitigation justify his discharging the Prisoner. Nay Mr. Dalton says, that where the Felony is proved to have been done, should the Party accused appear to a Demonstration innocent, the Justice cannot discharge him, but must commit or bail. And however absurd this Opinion may appear, my Lord Hale hath thought fit to embrace and transcribe it in his History of the Pleas of the Crown.

Id., Feb. 25, 1752, at 2, col. 2. The references Fielding appears to have had in mind are $\mathrm{M}$. DALTON, supra note 138, ch. 173, at 456 ("If any Felony be committed, and one is brought before the Justice of Peace upon suspicion for the same, though it shall appear to the Justice that the Prisoner is not guilty of that Offense, or that it is not Felony of Death, yet he may not set him at liberty, but so as he may come to his trial") (for similar discussion see id., ch. 159, at 382; ch. 164, at 408); 2 M. Hale, The History or THE Pleas or the Crown 46 
sures that made his Bow Street establishment a central clearing

- house for dealing with unsolved crime and for gathering evidence to be used at trial. The Covent Garden Journal carried a regular notice inviting "Persons who . . . suffer by Robbers, Burglars, \&c. . . . immediately to bring, or send, the best Description they can of such Robbers, \&c. with the Time, and Place, and Circumstances of the Fact, to Henry Fielding, Esq., at his House in Bow Street."242 By centralizing this reporting function, Fielding increased his ability to match up constables' arrests and the disclosures of crown witnesses with particular offenses. Fielding held public (and publicized) viewings of suspected persons and recovered goods, hoping to attract further identifications and to obtain additional prosecution evidence. ${ }^{243} \mathrm{He}$ cooperated with provincial JPs in this work (as had his predecessor, de Veil). ${ }^{244}$

(S. Emlyn ed. 1736) (2 vols.) (posthumous publication; Hale died in 1676) (JPs "cannot deliver a person by proclamation, as justices of gaol delivery may," but only on verdict).

Fielding's recommendation, which was part of the ultimate solution achieved under the stipendiary magistrate system of the nineteenth century, was that the JPs be given the power to dismiss or to convict in the case of small larcenies "where no Circumstance of Robbery, or any other Matter appear to aggravate the Theft, and when the Party shall appear to the Justices to be no old or hardened Offender." CGJ, supra note 122, Feb. 25, 1752 , at 2, col. 3. In the event of conviction the sanction that the JP could impose would be whipping or short-term penal servitude.

This proposal did not extend to the related problem that Fielding complained about in the extracted passage, someone accused of a serious felony but on insubstantial evidence. On the importance of the rule forbidding the JPs to discharge in such circumstances in the sixteenth century, see J. LANGBEIN, supra note 120, at 8. (In his forthcoming book treating criminal procedure in eighteenth-century Surrey, John Beattie will report instances of JPs dismissing in such cases, and he alerted me to look for these developments in the London sources.)

${ }^{242}$ CGJ, supra note 122, Jan. 25, 1752, at 3, col. 1 . For some antecedents of this system see George, The Early History of Registry Offices, in 1929 Econ. J. (Supp. 4) 570.

${ }^{243}$ E.g., CGJ, supra note 122, Jan. 25, 1752, at 2, col. 3, at 3, col. 1: Six persons "all impeached by an Accomplice, were committed for further Examination, till Tuesday next, when they may be all seen; and all whose Pockets have been lately picked, will, it is hoped, attend in Bow Street at that Time."

A few weeks later the paper invited the public to attend the examination of a suspected highway robber:

Whereas a tall young Fellow in a green short Waistcoat and a whitish Coat with Brass Buttons, a Silk Handkerchief about his Neck, with a short grey Wig and a flapped Hat, was apprehended at Finchley on Wednesday last, and brought on Thursday Morning before Justice Fielding; by whom he was committed for further Examination on Tuesday next, at twelve in the Forenoon; all Persons who have been lately robbed on Finchley Common, or any where on that Road, are desired to be present at the aforesaid Time, at the House of the said Justice in Bow Street, in order to see the Prisoner.

Id., Feb. 15, 1752, at 2, col. 3.

${ }^{244}$ Id., June 30,1752 , at 2, col. 3 (public notice regarding suspected highway robbers apprehended in Wiltshire, giving descriptions of men, horses, and some loot, and asking 
It appears that much of Fielding's pretrial examining of accused criminals was done before an audience in a public chamber in his residence. For example, the Covent Garden Journal reports him sitting on February 1, 1752, to examine upwards of thirty people who had been arrested by the constables for a miscellany of offenses (mostly petty crimes that, if adequately evidenced, would be referred for trial at Hicks Hall, the Middlesex equivalent of the provincial courts of quarter sessions). "[S]everal Members of Parliament were present at the above Examination ...."245 Another report in the paper's May 26 edition notes that a young man confessing a murder to Fielding at Bow Street "drew some Pity from the Crowd who were present.."248

In his Enquiry of 1751 Fielding expressed an interest in the pawnbrokering industry as a potential pressure point for restraining and detecting larceny. "It is a very old and vulgar, but a very true Saying," he writes, "'that if there were no Receivers, there would be no Thieves." "247 If receiving could be suppressed, "there would be an absolute End of several Kinds of Theft; such as Shoplifting, Burglary, \&c., the Objects of which are generally Goods and not Money." $248 \mathrm{He}$ recommends some changes in the laws dealing with receivers, and he wonders, "[i]s it impossible to find any Means of regulating Brokers and Pawnbrokers?"248 In 1752-1753 the House of Commons deliberated and finally passed legislation on this question, but it foundered in the Lords. ${ }^{250}$

victims or other witnesses to contact, among others, Henry Fielding in Bow Street); DE VEIL BIOGraphy, supra note 224, at 46-47 (aiding in a Suffolk murder case).

218 CGJ, supra note 122, Feb. 4, 1752, at 2, cols. 1-2 (the dispatch is dated February 3 but describes a sitting the previous Saturday, which was February 1).

246 Id., May 26, 1752, at 2, col. 3.

217 H. FrkLding, ENQuiry, supra note 186, at 68.

248 Id.

249 Id. at 74.

180 The Commons committee report of Jan. 17, 1752, that underlay the draft legislation called for a variety of measures: (1) licensing of London-area pawnbrokers; (2) mandatory record keeping of pawn transactions; (3) a ban on night-time pawns; (4) criminal liability, probably misdemeanor, for pawnbrokers who bought goods that had already been advertised "in some one public Paper," but also a statutory reward for pawnbrokers who responded to such advertisements; (5) provision to encourage prosecution of offending pawnbrokers by empowering the trial court to award to the prosecutor all or part of the fine assessed on the pawnbroker; (6) a duty to detain and bring before a JP any person attempting a pawn whom the pawnbroker suspected "not to have come honestly thereby," together with a statutory defense for civil suits arising from such detentions; and (7) regulation of interest rates and redemption periods. 26 H.C. Jour. 381-82 (1803). For other proceedings in the Commons, see $i d$. at 345 (appointipg committee), 441 (first reading of bill), 447, 452, 455-56 (second reading and proposed amendment), 458-59 (petition of pawnbrokers protesting "that there is no Possibility of carrying on Business upon the Terms of the Bill depending"), 464, 465, 
Fielding fashioned a scheme for dealing with the pawnbrokers that he put into operation in late 1752. It represented a further refinement of the clearing house concept, and we shall see it much evidenced in the work of John Fielding in the Ryder years. In the final issue of the Covent Garden Journal, for November 25, 1752, a group of nearly sixty men styling themselves "the principal Pawnbrokers" of the London area gave notice that they would all subscribe to a refounded newspaper, Public Advertiser (of which Henry Fielding was a part owner). Their announcement explained that "if any stolen Goods shall be advertised in that Paper, we will, to our utmost, endeavour to secure the Property for the Owner, and to bring the Offender to Justice." ${ }^{.251}$ There followed a notice from Fielding that he would use the same publication for his public notices and that his clerk was available to place advertisements there on behalf of persons who lost goods. ${ }^{262}$

The gist of this scheme was to centralize and to bring within Fielding's domain the process by which citizens advertised for the return of stolen goods; further, he linked the advertising system with an undertaking by the pawnbrokers to cooperate in reporting attempts to sell advertised goods. (This also constituted another chapter in the long saga of efforts to prevent victims from reacquiring their goods by compounding with the thieves. ${ }^{263}$ ) It gave citizens an incentive to report and advertise thefts promptly in order to reach the participating pawnbrokers. The pawnbrokers also had reason to cooperate. It was customary for persons advertising for the return of lost goods to offer a reward, which the pawnbroker who "stopped" stolen goods could claim. Moreover, pawnbrokers who adhered to the plan would be protecting themselves from potential criminal liability for receiving stolen goods. ${ }^{254}$

476, 480, 490 (third reading and passage), 588 (new bill), 639, 658, 714, 730 (first, second, third readings and passage). For proceedings in the Lords, see 28 H.L. Jour. (n.d.), recording only the receipt of the new bill, $i d$. at 69 , and its rejection, id. at 101 . I see a closer correspondence between Fielding's views and the proposal in the Commons report than does Amory, supra note 178, at 185.

A rather different scheme of restraining pawns and adjusting the claims of pawnbrokers and owners was enacted a few years later. 30 Geo. 2, ch. 24 (1757).

${ }^{231}$ CGJ, supra note 122, Nov. 25, 1752, at 2, col. 1.

${ }^{252}$ Id., col. 2. For a set of rules for the pawnbrokers attributed to Henry Fielding, see J. Frelding, Account, supra note 234, at 57-59.

${ }^{25 s}$ Especially the so-called "Jonathan Wild Act," the statute of $4 \mathrm{Geo}$., ch. 11 (1717); see generally G. Howson, supra note $25 ; 1 \mathrm{~L}$. RADzINowicz, supra note 49 , at 682-84. An Act of 1752 threatened a 50-pound fine against either the advertiser or the printer of a "noquestions-asked" reward offer. 25 Geo. 2 , ch. 36 (1752).

${ }^{254}$ In a case tried by the Recorder, Moreton, at one of Dudley Ryder's Old Bailey sessions, the judge is quoted by the OBSP snapping at a pawnbroker-witness: "You pawnbro- 
3. Police. Henry Fielding's system required some ground troops, people prepared to go out and apprehend suspects against whom information had been given, to aid in the retaking of goods, and in special circumstances to patrol and to infiltrate gangs-in short, a police force. In the early 1750s Fielding was bringing together such a force of quasi-professional constables, numbering perhaps half-a-dozen men, who came to be called the Bow Street runners. He used as compensation a patchwork of direct subsidy, reward money, and preferment to other offices. ${ }^{25 s}$

\section{B. John Fielding in the Ryder Years}

In May 1754 Dudley Ryder was named Chief Justice of King's Bench. Henry Fielding sailed for Portugal in June, having "resigned the office and the farther execution of my plan to my brother, who had long been my assistant."258 John Fielding moved to Bow Street that summer. He was Henry's half-brother, by a different mother. John had been afflicted with total blindness from his youth, which is why portraits such as that reproduced in this article show him with a black band above his eyes. Henry Fielding died in Lisbon in October 1754 as Dudley Ryder was preparing for his first Old Bailey sessions.

The Middlesex caseload processed before Ryder and his fellow trial judges was considerably influenced by the system Henry Fielding had patched together. In the form of advertisement that John Fielding ran regularly during the Ryder years in the Public Advertiser we can see the interrelationship of Henry's various measures: centralization of crime reporting and of the advertising of stolen goods; cooperation of the pawnbrokers; a shadowy police force for following up; and all of it supervised by the examining magistrate, now John Fielding, who would build the prosecution case for trial at the Old Bailey. The notice reads:

WHEREAS many Thieves and Robbers daily escape Justice for Want of immediate Pursuit, it is therefore recom-

kers are the bane of society; it is a question but if you were to be indicted for receiving those goods, knowing them to have been stolen, but that this worthy jury would find you guilty." Anne Moore, OBSP (Apr. 1755, \#177), at 160, 162. The risk of having to defend such a prosecution was greatly diminished if a pawnbroker cooperated in the Fielding system, by following the advertisements and giving prompt notice as occasion arose.

235 See Amory, supra note 226, at 190; H. Firlding, LisBon Diary, supra note 227, at 191-92; J. Firlding, Account, supra note 234, at 15-18; J. FirdDING, PLAN, supra note 234; 3 L. RADzINowicz, supra note 49, at 54-56.

258 H. Fielding, Lisbon Diary, supra note 227, at 194 n.1. 


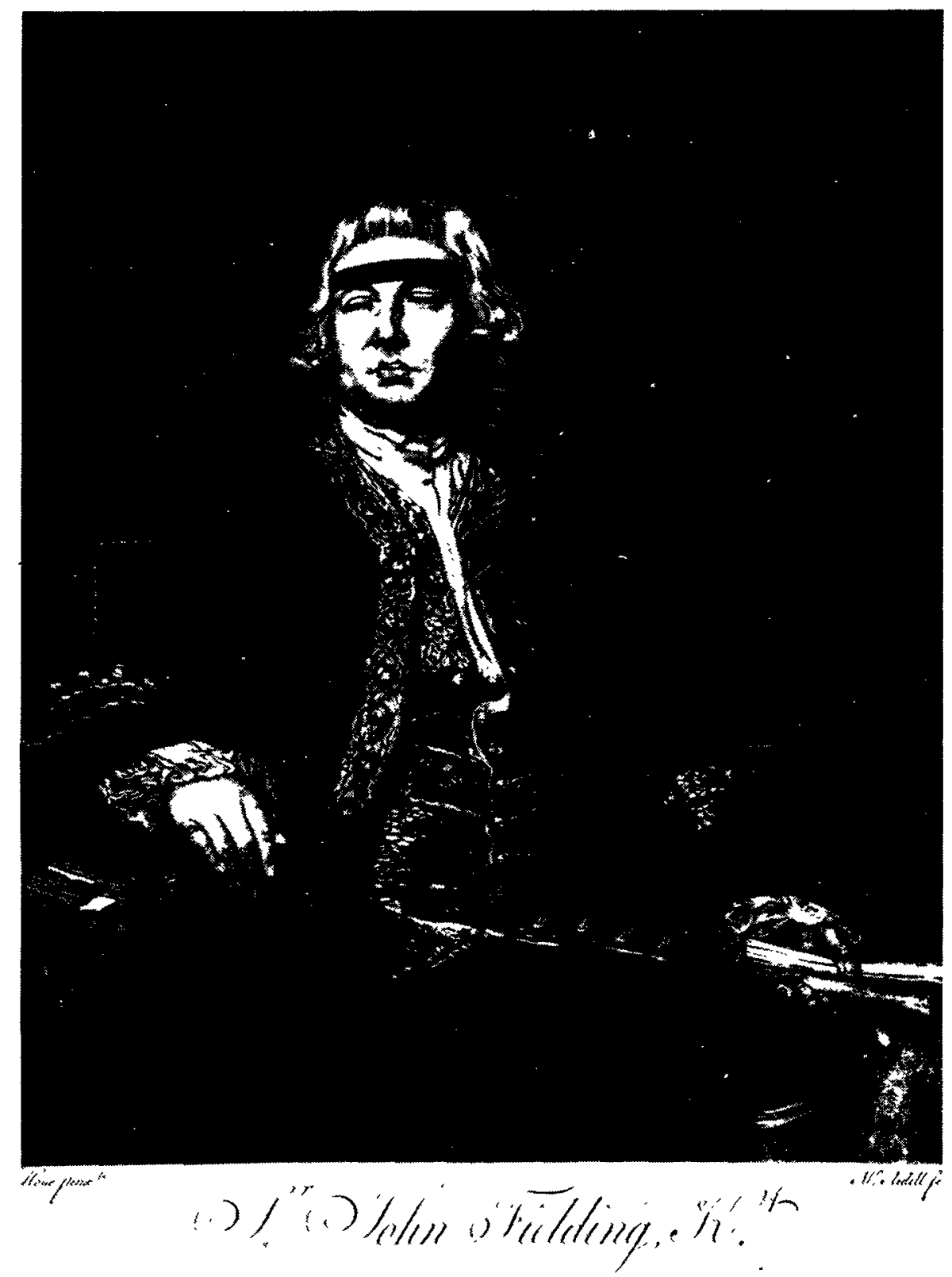

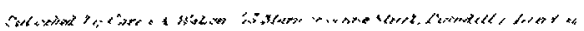


mended to all Persons, who shall henceforth be robbed on the Highway or in the Streets, or whose Shops or Houses shall be broke open, that they give immediate Notice thereof, together with as accurate a Description of the Offenders as possible, to John Fielding, Esq., at his House in Bow Street, Covent Garden: By which Means, joined to an Advertisement, containing an Account of the Things lost (which is also taken in there) Thieves and Robbers will seldom escape, as most of the principal Pawnbrokers take in this Paper, and by the Intelligence they get from it, assist daily in discovering and apprehending Rogues.

And if they would send a special Messenger on these Occasions, Mr. Fielding would not only pay that Messenger for his Trouble, but would immediately dispatch a set of brave Fellows in Pursuit, who have been long engaged for such Purposes, and are always ready to set out to any Part of this Town or Kingdom on a Quarter of an Hour's notice.

It is to be hoped, that the late Success of this Plan will make all Persons for the future, industrious to give the earliest Notice possible of all Robberies and Robbers whatever. ${ }^{257}$

Our sources feature constant reference to the pretrial work of John Fielding. At the October 1754 sessions, for example, of twenty-eight Middlesex cases, the reports mention pretrial activity by a magistrate in eighteen. (The other ten are mostly cases neither tried by Ryder nor fully noticed in the OBSP - that is, squib reports.) of the eighteen cases with magisterial activity traceable in the Ryder notes or the $\mathrm{OBSP}^{258}$ for the particular sessions, Fielding had served as the examiner and committal officer in nine.

Our cases show many permutations of the basic scheme envisioned in John Fielding's notice. Sometimes the victim had done his own investigating, which Fielding simply confirmed before committing the accused. ${ }^{258}$ Occasionally, the pawnbroker initiated

${ }^{287}$ Public Advertiser, Feb. 7, 1755, at 1, col. 2.

2ss There are better sources than the OBSP and the Ryder notes for quantitative study of the pretrial work of the various Middlesex JPs and London aldermen. The recognizances used to bind over the prosecutor and his witnesses for trial survive in the Middlesex and Corporation of London Record Office sessions files. Since the committing magistrate signed each, it would be possible to tabulate fairly accurately the activity of the Fieldings and the others.

230 E.g., Elizabeth Cooper, OBSP (Oct. 1754, \#494), at 319; William Powel, OBSP (Apr. 1755, \#154), at 147; Mary Clinch, OBSP (Apr. 1755, \#197), at 183; Elizabeth Broomhall, OBSP (Oct. 1755, \#375), at 332; Ryder Notebook, supra note 19, at 35. 
a case without waiting for an advertisement, when he sensed that a proferred pawn was suspect. Thus, when a charwoman, Sarah Jones, attempted to pawn a silver mug, the pawnbroker "stopped it, and her, and took them both to Mr. Fielding's, where was Mr. Welch."280 (The reference is to Saunders Welch, long-time high constable of Holborn and a close associate of Henry Fielding, who had become a JP in 1755 and was sitting in John Fielding's stead at Bow Street on the day of the events. ${ }^{261}$ ) Under questioning by Welch the culprit confessed the theft in the hearing of the pawnbroker, and then again to the owner, who "was sent for to justice Fielding's and there saw my mug."282

Sometimes we see John Fielding guiding a case through several stages of detection and evidence-gathering. At the trial of James Finn in April 1755 for burglary of household silver from a dwelling, the victim recounted what had happened in the pretrial process. ${ }^{263}$ Awakening in the morning to discover the break-in, he sent a neighbor's "young man [to] run about among the pawnbrokers to see if any of the things had been offered to pawn." He discovered in this way that "the prisoner and his wife had offered to sale [sic] a pair of tea-tongs at a house in Drury Lane. I went and got a search-warrant of justice Fielding." The victim took a constable and went to search the house where Finn was believed living. They found him "in the cellar, with part of the goods in his pocket, and we found part under his bed .... We took the prisoner

${ }^{280}$ Sarah Jones, OBSP (Apr./May 1756, \#182), at 163. Another: Elizabeth Wright, OBSP (Apr./May 1756, \#224), at 174; Ryder Notebook, supra note 19, at 57. Pawnbrokers' advertisements that appear in the Public Advertiser instance this practice. See, e.g., Public Advertiser, Dec. 12, 1755, at 2, col. 3:

Stopped on Saturday the 6th instant, at the Three Blue Bowles in Tothill Street, Westminster, of a young Woman, two old-fashioned Table Spoons, pretty much wore, marked with three Letters. Any Person applying to the above mentioned Place, may have them again, by giving Descriptions, and paying for this Advertisement.

201 For a few details on Welch see $3 \mathrm{~L}$. Radzinowicz, supra note 49 , at $54 \mathrm{n}$.1. Welch is noticed in R. Leslie-Melville, The Life and Work of SiR John Fielding passim (1934) (see entries indexed under Welch, id. at 322-23).

Leslie-Melville treats the relationship between Fielding and Welch as intimate and harmonious. In fact, Fielding was at one point so peeved at Welch that he complained about him to the Treasury. PRO, T 1/372/109 (Treasury Board Papers) ("Letter from Bow Street, 8 Dec. 1757"). Fielding recites that whereas Welch previously agreed with the Treasury to keep his justicing office in the Hatton Garden neighborhood, "he continues to come every Day to a Place near my House to officiate as a Justice of the Peace." Fielding asks the Treasury to get Welch out. "Were I to mention it myself to Mr. Welch it might occasion a Dispute, which I am at all Events determined to avoid . . . ." Id.

${ }^{282}$ OBSP (Apr./May 1756, \#182), at 163.

288 James Finn, OBSP (Apr. 1755, \#155), at 147, 148. 
before the justice . . . "264 Finn offered as his alibi that a passing stranger tossed the stolen silver into his apron-not a very auspicious defense, but one that Fielding probed, as the victim later testified at trial: "I made a remark before the justice, that the glass of the window [of the burglarized house] was bloody, the justice ordered us to look at the prisoner's hands [something which Fielding, being blind, could not do himself]. I found two scratches on them that seemed to be quite fresh done; the justice committed him to New prison."28s

The Ryder sources also evidence situations that follow the script envisioned in John Fielding's recurrent public notice reproduced above. In Ryder's final sessions in 1756, Agnes Kirby and Mary Hardis were prosecuted before him on April 28 for a theft committed six days earlier. ${ }^{268}$ (This is a notable illustration of the rapidity of the criminal procedure of the era, a subject discussed in the former article and again in Part VII below. ${ }^{267}$ ) The victim, Lydia Williams, a shopkeeper, testified that the two women came into the shop pretending to examine material needed to make borders for their caps. "I suspected these women. Upon looking over my things I missed [the goods]. My husband advertised them, and on search among pawnbrokers we had intelligence of them."268 The husband must have lost little time in going to Fielding, for the following advertisement ran in the Public Advertiser the next day:

Whereas two Women came into a Linen Draper's Shop in Holborn, between One and Two o'Clock on Thursday last, under Pretense of buying Goods, but instead thereof privately took away one Piece spotted Lawn, one Piece striped spotted and checked, one Quantity of Chintz Pattern Linen. Whoever will discover either of the aforesaid Women, so that they may be apprehended and brought to Justice, shall receive one Guinea Reward upon Conviction, to be paid by John Fielding Esq. ${ }^{269}$

The pawnbrokers' information led to arrests of the two women; a constable "found the goods partly with one and partly with the

2er Id. at 148.

285 Id.

ses OBSP (Apr./May 1756, \#\#210-11), at 171 (squib report); Ryder Notebook, supra note 19 , at 54 .

${ }^{267}$ See Article I, supra note 1, at 277-84; infra notes $459-95$ and accompanying text.

ses Ryder Notebook, supra note 19, at 54-55.

260 Public Advertiser, Apr. 23, 1756, at 2, col. 3. 
other prisoner."270 Examined before Fielding and Welch, each claimed that she thought the other had paid for the goods. (The jury at the Old Bailey acquitted them, apparently unable to decide which was the culprit. ${ }^{221}$ )

We sometimes have trial testimony about Fielding's role in framing advertisements. In the prosecution of Charles Cane for shoptheft, discussed in another context in Part V below, ${ }^{272}$ one victim is quoted as saying: "I went and told justice Fielding the case, who advised me to put it in the papers, with five guineas reward, which I did."27s

Then as now, pretrial examination could have the effect of freezing testimony while recollections were fresh, making it easier to refute later alterations and inventions. The trial of Rowley Hanson, convicted in October 1755 for stealing a watch in a highway robbery, instances this use of a pretrial examination taken before Fielding. Hanson contended that the prosecutor gave him the watch as a bribe in exchange for Hanson's promise not to prosecute him for supposedly making homosexual advances to Hanson. The prosecutor responded: "Here is the prisoner's account [tht] he gave before the justice, in which he owns he never saw me before he saw me at the justice's." Thereupon John Fielding's clerk, the same Joshua Brogden inherited from de Veil and Henry Fielding, produced the written examination of Hanson taken at the pretrial hearing, and testified that he, Brogden, "was by when the prisoner was examined before Mr. Fielding and Mr. Welch." Hanson then had said "that he never to his knowledge in his life had seen the [prosecutor] then present."274 Hanson was convicted, sentenced to death, and executed.

The constables who are mentioned in the testimony of other witnesses are more often referred to by office than by name. Both the OBSP reports and the Ryder notes preserve the names of witnesses who testify, however, so that when the constable testifies we can sometimes spot him as a member of Fielding's special force. William Pentlow, the best known of these men, ${ }^{275}$ appears in the OBSP report of the October 1754 prosecution of Charles Flemming (sometimes Fleming) for highway robbery. Pentlow testified that

\footnotetext{
270 Ryder Notebook, supra note 19, at 55.

273 Id. at 55-56.

273 See infra notes 328-53 and accompanying text.

178 OBSP (Apr./May 1756, \#200A), at 168; Ryder Notebook, supra note 19, at 46.

274 OBSP (Oct. 1755, \#370), at 329, 330.

${ }^{275}$ See 3 L. Radzinowicz, supra note 49, at 55.
} 
he organized a jailhouse lineup with Flemming and a dozen or so others "at the desire of justice Fielding, to see whether [the victim's coachman] knew Mr. Fleming."276 He did, and Flemming was convicted, sentenced to death, and executed. Fielding later wrote about Pentlow's role in the case: "The fate of Fleming, the late highwayman, who was supposed to have subsisted three or four years by the road [that is, engaged in highway robbery], is a proof of [the value of having agents conversant with the underworld]; for it was a description of his way of life, told as a matter of conversation to Mr. Pentlow ... that was the occasion of his being apprehended."27z

It seems that John Fielding conducted his examinations in a public chamber whose audience included persons having no particular connection to the case, a practice that he inherited from Henry Fielding and that has been remarked above. ${ }^{278}$ We see such a sitting illustrated in an engraving reproduced in this article, which purports to show the Bow Street premises "with Sir John Fielding presiding, \& a Prisoner under examination." The picture gains verisimilitude from having been published during Fielding's lifetime and in a book dedicated to him. ${ }^{279}$ This practice of public examination of suspects is evidenced in one of the cases in our sample. William Whitewell was tried in the April 1755 sessions for stealing a silver spoon from the house of the bishop of Kildare. ${ }^{280}$ The bishop's butler testified at the trial, explaining how an advertisement by a silversmith (here functionally the equivalent of a pawnbroker) led to the recovery of the spoon and the identification of the culprit. "After that the spoon and prisoner was [sic] brought to justice Fielding by the silversmith; I went there, and knew the spoon to be the property of my lord bishop. The justice asked the prisoner if he was guilty? He said he was. This answer he made twice over." The silversmith testified to the details of Whitewell's attempt to sell the spoon. He said that at Fielding's he "heard the prisoner twice own before [Fielding] that he took the spoon; after that the people said, 'Why do you confess? Why do you confess?'

276 OBSP (Oct. 1754, \#505), at 330, 331.

277 J. Fielding, Plan, supra note 234, at 10.

278 Seé supra text accompanying notes 245-46.

270 The Malepactor's Register; OR, tHe Newgate and Tyburn Calendar (London n.d. [1779]) (5 vols.). The engraving discussed in text appears as the frontispiece to Volume 3. Volume 1 dedicates the set to Fielding. 1 id. at iii. The engraving is reproduced as the frontispiece in R. LESLIE-MeLviLLe, supra note 261.

280 OBSP (Apr. 1755, \#161), at 151. 


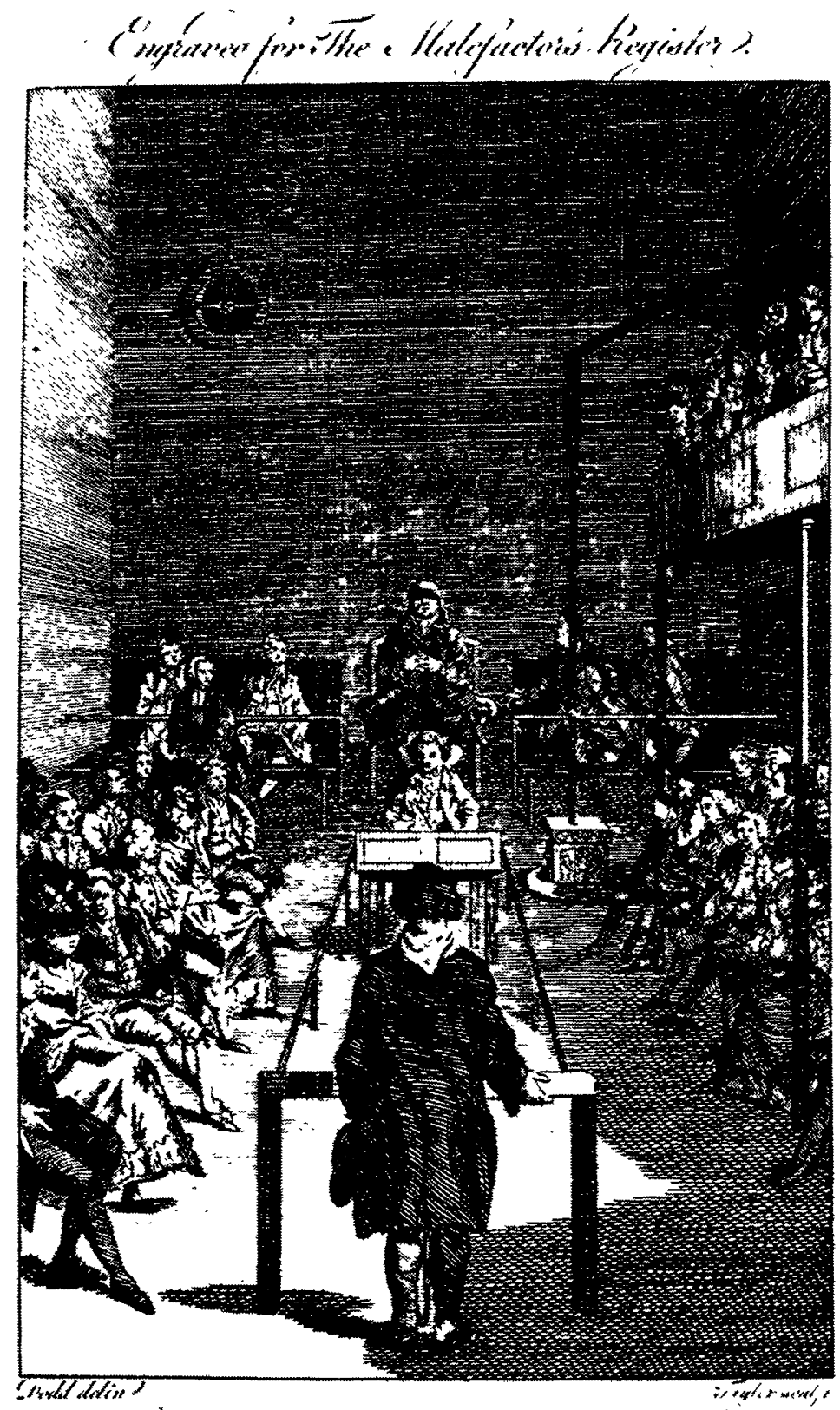

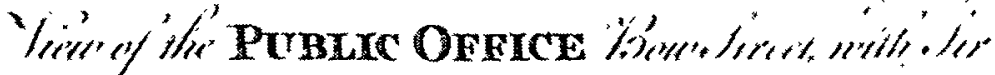

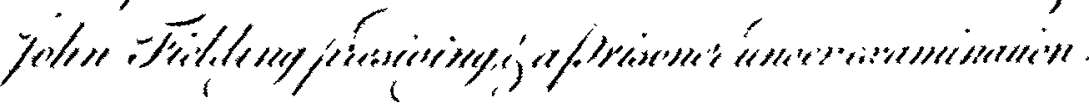


Then he stiffly denied it."281

The frequent appearance of pawnbrokers in the cases we have been discussing is, of course, no fluke. The Fieldings' system had been designed to encourage it. By my count, thirty of the 171 cases in the Ryder sessions involved pawnbrokers, and several more featured a silversmith or a pewterer in a role that amounted to that of a specialist pawnbroker. In order to appreciate what an astonishing proportion these pawnbroker cases represent, due regard must be given to two factors affecting the balance of the cases in the sample. Many are known only from squib reports in the OBSP, where such detail was easily lost. More importantly, a high proportion of the remainder of the offenses in our sample could not have involved pawnbrokers: for example, when the accused was caught in the act or in pursuit or with the goods, when the crime was not a theft, or when money or a consumable was stolen rather than marketable goods.

The Fieldings' diligence and the apparent success of their package of pretrial techniques gave rise to a curious complacency. John Fielding boasted in 1761 that "by bringing all Informations of Fraud and Felony into one Point, keeping a Register of Offenders, making quick Pursuits, opening a general Correspondence with all the active Magistrates in the Country, Escapes are rendered difficult, and Discoveries easy.","282 A nation still essentially without a police force hurtled into the urban industrial age priding itself on its police. In the countryside, squires and parsons in the commission of the peace and their yeoman helpers in the amateur constabulary continued more or less as before, while the problems of the metropolis could be thought to be under control. As late as 1785 the Reverend Martin Madan held up the English arrangements for comparison with France, whose system of public police was then renown ${ }^{283}$ in England:

Our police, as far as it relates to the discovery and apprehension of felons, is now on such a footing, that no thief, or nest of thieves, can long be safe. The plan of a public office, open at all times for the examination and commitment of offenders, is of the greatest use. This was first devised by the late $H$. Fielding, Esq.- much improved on by his late brother Sir John Fielding - and is now carried on, in a still improved-

282 J. Fielding, Extracts from Such of the Penal Laws as Particularly Relate to the Peace and Good Order of This Metropolis 4 (London 1761).

sss 3 L. Radzinowicz, supra note 49 , at 539-74. 
state . . . in Bow Street. ${ }^{284}$

Madan also pointed to the sitting alderman system in the city of London, discussed next below, and concluded with the remark that "I much question whether a thief can be much safer in England, even in London itself . . . than he would be . . . in France."28s

\section{The Sitting Alderman and the Lord Mayor}

During the decades that de Veil and the Fieldings were shaping the court JP system in Middlesex, the city of London was refining a broadly comparable although somewhat more institutionalized system of pretrial procedure. The city shared with Middlesex some of the traits that made it impractical to attempt to detect and prosecute criminals in the casual fashion of the provinces. The city was densely populated and it exhibited in many respects the impersonality characteristic of urban life, although it had not experienced the very rapid growth that Middlesex was undergoing. The city contained about a quarter of the population of greater London ${ }^{286}$ but was broken into twenty-six wards that retained some communal character. ${ }^{287}$

"The boundaries of the City of London have not altered materially since the Norman Conquest and enclose a small area of 677 acres, forming the heart of the metropolis."288 The twenty-six wards served many purposes, such as providing watchmen, comparable to the practice of rural parishes. Each ward sent an alderman to the several so-called courts that governed the city. ${ }^{289}$ The Lord Mayor of London was chosen from among the more experienced aldermen for a one-year term. ${ }^{280}$ The commission of the peace for the city "constituted all the Aldermen Justices of the Peace."281

By the Ryder years the work of pretrial examination for cases of felony arising in the city was being allocated among the aldermen and the Mayor in an organized fashion. This practice contrasts with that of Middlesex, where the single "principal magis-

${ }^{284}$ M. MADAN, supra note 49, at 131-32 (emphasis in original).

${ }^{285} \mathrm{Id}$. at 133 (emphasis in original).

${ }^{286}$ The population of the city is shown as 123,089 in 1695 and 128,833 in 1801 in CoRPORATION HISTORY, supra note 28 , at 121 . On the population of greater London see supra note 169.

${ }^{287}$ Corporation History, supta note 28 , at 27.

288 Id. at 7.

${ }^{289}$ See $2 \mathrm{~S}$. Webb \& B. Webi, English Local Government: The Manor and the BoROUGH 576-79, 616-70 (1908).

290 Corporation History, supra note 28, at 7-12, 15-17, 27.

${ }^{291}$ Id. at 60 (citing charter of 15 Geo. 2, Aug. 25, 1741). 
trate" (John Fielding in our period) dealt with perhaps half the cases arising in the sprawling county, the rest being scattered among other Middlesex JPs, primarily we suspect on the ground of the victim's convenience in locating a JP. In the city the practice of the early decades of the eighteenth century had been to concentrate the pretrial work in the hands of the Mayor; he was aided by a clerical establishment whose character and role in these matters has not been researched. Probably "in order to relieve the overburdened Lord Mayor," known as the "sitting alderman" system. "Regular daily sittings of an Alderman at Guildhall began on 12th December, 1737, although it is possible that Aldermen held occasional sittings prior to that date."28s

Thereafter the city operated two centers for justicing business, including the pretrial examining work in felony cases. The Mayor sat in his official residence, Mansion House, while the aldermen sat in a daily rotation at the Guildhall. This system survived into recent times. An official publication of 1950 explained: "For the purpose of the division of work between the two . . . the City is divided into two approximately equal divisions by a line running along Gresham Street and continuing east and west to the City boundary. The Mansion House takes all cases arising south of this line and the Guildhall those arising north of it."294

This system was thriving in the Ryder years, ${ }^{295}$ and our trial sources evidence it frequently in witness testimony. ${ }^{206}$ For example: "We took him before the sitting alderman at Guildhall; there

202 [P.E. Jones], The City Justices and Justice Rooms, 3 Transactions of the G.H.A. [Guildhall Historical Association] 33, 36 (1963). A typescript draft and an earlier manuscript of this article, attributed to P.E. Jones, former archivist of the Corporation of London Record Office, is filed there. CLRO, Research Papers Box 5.19 (envelope captioned "Justice Rooms"). (I owe this reference to Steven Macfarlane.) The published text, hereafter cited as Jones, Justice Rooms, was, according to the table of contents for the volume, "[r]ead by Alderman C.J. Harman, October 29th, 1956."

${ }^{203}$ Jones, Justice Rooms, supra note 292, at 36.

29 CORPORATION History, supra note 28, at 63.

${ }^{205}$ The division of business can be seen from the manuscript recognizances that survive for both Old Bailey and quarter sessions matters in CLRO, Old Bailey Sessions Files. For example, the file for October 1754 contains about 30 recognizances, on one or another of three fill-in-the-blank printed forms; 13 are signed by Thomas Rawlinson, mayor, at the Mansion House. Those originating with the sitting alderman recite that they were taken at the Guildhall.

${ }^{296}$ I use the terms "witness" and "testify" to include the declarations of the accused, who was not allowed to speak on oath, and who was not, therefore, testifying in the strict sense. For the background and later history of the rule excluding criminal defendants from testifying under oath, see generally Bodansky, The Abolition of the Party-Witness Disqualification: An Historical Survey, 70 Ky. L.J. 91, 105-29 (1982). 
he was charged with stealing [the goods in question]. He said very little for himself." ${ }^{29 z}$ In another case: "I gave the watchman charge of [two women charged with picking the prosecutor's pocket], he took them into custody, and they were sent to the compter [a jail]. The next morning they were carried before my Lord Mayor, and I was bound over to prosecute." 298 This sort of reference occurs in twenty of the cases in our sample, and in most of the rest of the city cases the report is too brief for mention to have survived.

In one of the Ryder cases the OBSP report preserves mention of an arresting constable testifying that "while we were in the matted gallery at the Guildhall, [the accused] owned he picked the gentleman's pocket."289 Regarding the chamber where justicing work was conducted, a modern authority explains: "Accommodation for the Aldermen sitting at Guildhall was provided by a partition in what was known as Matted Gallery ....."300 Hogarth worked the institution of the sitting alderman into Plate 10 of his "Industry and Idleness" series, in which the "idle apprentice" (who in his youth deserts his exemplary colleague, the "industrious apprentice," for a life of crime) has been apprehended for felony and is brought before his erstwhile colleague, now grown rich and successful and shown exercising the office of sitting alderman. ${ }^{301}$ The Palladian setting that Hogarth depicts in the plate, which is reproduced in this article, is, however, idealized. Surviving architectural drawings represent the matted gallery as having only a thirteenand-a-half foot floor-to-ceiling clearance, ${ }^{302}$ which could not have accommodated the double gallery in the Hogarth. (Plates 11 and 12 of Hogarth's series show the idle apprentice being carted to the gallows at Tyburn while the industrious apprentice rides in procession to become Lord Mayor of London. ${ }^{303}$ )

At both Mansion House and the Guildhall, records were produced that contained minutes of the justicing work done there, but

287 James Welch, OBSP (Oct. 1755, \#382), at 338.

298 Sarah Mathews \& Elizabeth Jones, OBSP (Apr./May 1756, \#\# 180-81), at 163; Ryder Notebook, supra note 19, at 54 .

299 Charles Frigatee, OBSP (Apr. 1755, \#182), at 169, 170; Ryder Notebook, supra note 19 , at 27 .

300 Jones, Justice Rooms, supra note 292, at 36 .

301 See 2 R. Paulson, Hogarth's Graphic Works, Plates 180-91 (1965) for the entire series [hereafter cited as Hogarth's Works]; see 1 id. at 200 for editorial detail on Plate 10. Preliminary drawings for Plate 10 are reproduced in 2 R. PAuLson, Hogarth: His LIFE, ART, AND Times 69 (1971). Paulson dates the series to circa 1747. Id. at 75.

${ }^{302}$ CLRO, Surv. CLB 60 (n.d.); CLRO, Surv. CLB 61 (1773).

${ }^{303}$ See 2 Hogarth's WoRks, supra note 301, Plates 190-91. 


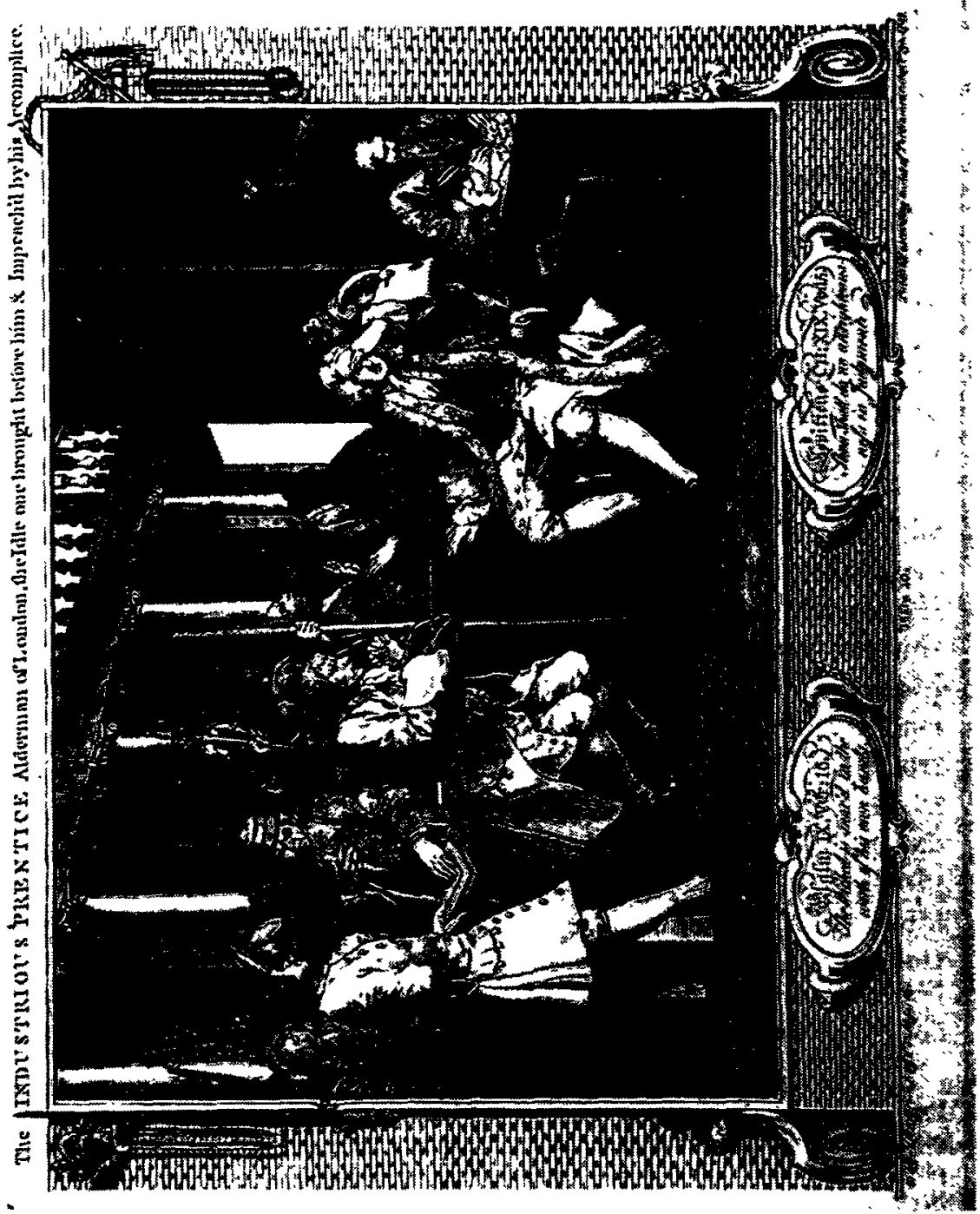


they do not appear to have survived for the Ryder years. ${ }^{304}$ For period of a few weeks in May/June 1752, however, one volume ${ }^{305}$ of the Guildhall minute books does survive, and it illuminates the institution that we see a couple of years later in the Ryder sources. Folded into the front cover of this manuscript minute book is an outsize printed sheet containing a calendar of aldermen's assignments for an entire year, commencing in October 1751. Twentythree aldermen appear in the rotation, scheduled for service about once a month. The names and dates of the actual aldermen's service recorded in the May/June minute book correspond to the advance assignments in the calendar for the most part but not invariably-sometimes one alderman sat in deputation of another.

The rotation system necessarily impaired continuity in pretrial investigations where follow-up steps extended beyond a day, and the Guildhall minute books helped new examiners to pick up the thread. By way of illustration we can trace a felony investigation from the 1752 minute book through to trial in the OBSP. On Friday, May 29, a watchman and a constable brought William Robinson before the sitting alderman, Thomas Rawlinson, "on suspicion of stealing a parcel of Cobbler's working Tools and old shoes [that the watchman] stopped him with near Smithfield about 2 o'clock this morning." Rawlinson ordered him detained "for further examination till the Goods are Advertised." ${ }^{306}$ We learn from the trial evidence in the OBSP report for June 1752 that this step proved fruitful. The constable testified that "by advertising ${ }^{[307]}$ I found there were seventeen cobblers' stalls broke open. . . . [T] $]$ he prosecutor [that is, the victim] came and owned the goods. I took six picklock keys out of the prisoner's pocket." 308 On the Monday following the arrest, the victim and his son, as well as the culprit and the two lawmen, appeared before the sitting alderman, Thomas

sos CLRO, 204B (Minute Books of Proceedings of the Guildhall Justice Room). After the volume from 1752, infra note 305, the holdings lapse until 1761-1762, for which a few weeks' worth survive, and again until 1775 , where the survivals become more extensive, especially from the $1780 \mathrm{~s}$. (I owe the reference to these sources to Joanna Innes and John Styles.)

sos CLRO, 204B ("Guildhall Minute Book, Beginning Monday 25th May 1752 and Ending Tuesday 19th June 1752") (unpaginated) (hereafter cited as 1752 Guildhall Minute Book].

${ }^{300}$ Id. (entry for May 29).

${ }^{502}$ In this usage I suspect that the word "advertising" meant sending someone around to make inquiry. In the OBSP report the victim testifies that "a young man came and told me the things were at the constable's; I went, and there I found them." William Robertson [sic], OBSP (June 1752, \#394), at 236.

${ }^{303}$ Id. at 237. 
Chitty, sitting in deputation of the scheduled William Whitaker. The victim and his son identified the goods, and the watchman repeated his story for the new alderman, who bound over all three to prosecute at the next Old Bailey sessions. ${ }^{309}$ At the trial Robinson's entire defense as recorded in the OBSP report was: "I bought these things in Rag fair of a woman." $110 \mathrm{He}$ was convicted and transported. ${ }^{311}$ We note in passing that both the recognizance to prosecute and the indictment characterize the offense as simple larceny (feloniously stealing ${ }^{\mathbf{3 1 2}}$ ), although the facts would have supported charging the nonclergyable offense of breaking and entering. Here, therefore, the downcharging decision appears to have been made at the pretrial examination stage.

We do not find in the Ryder sources examples of sustained aldermanic or mayoral investigation comparable to the gangbusting work of John Fielding in some of the Middlesex cases. The role of the city examiners, as reflected in the trial evidence upon which we mostly rely, seems to have been more passive. The rotation system at the Guildhall necessarily diffused investigative responsibility. The police force on the ground, however, was stronger and better organized than in Middlesex, and it had far less area and far fewer people to superintend. This, together with the rather more settled, more communal, and less turbulent character of the city, may have compensated for the want of a John Fielding.

To conclude: An officially supervised pretrial process lay behind virtually every felony trial in the Old Bailey in the Ryder period. Overseen by magistrates and aldermen, constables and watchmen helped victims to seize culprits and goods. Pretrial examination helped dispose of weak cases without trial while reinforcing the evidence for cases that went to trial.

\section{Proving Pretrial Confessions}

A main evidence-gathering function of the pretrial process administered by the JPs was to generate timely confessions that could later be reported to the trial jury. In our Old Bailey sources we see these pretrial confessions with great frequency, and we suspect that they underlay many or most of the squib cases, the cases

sos 1752 Guildhall Minute Book, supra note 305 (entry for June 1); see CLRO, Old Bailey Sessions File, June 1752, Recognizance no. 11.

s10 OBSP (June 1752, \#394), at 237.

311 Id. at 239.

312 Recognizance no. 11, supra note 309 ; the indictment is preserved in the same Session File, unnumbered. 
of so little interest that the OBSP omit the narrative. ${ }^{313}$

Over the course of a century or so culminating in the Ryder years, we detect some change in the mechanics of proving these confessions to the jury. The Marian committal act of 1555 , the statutory foundation of the pretrial process, required the JP to "certify" to the trial court his written examinations (which came to be called depositions) of victims, witnesses, and accused. ${ }^{314}$ In the second half of the seventeenth century, according to the generally reliable Clerk of Assize manual, the JP routinely surrendered his depositions in advance of trial to the clerk, who studied each; "and if it be Evidence for the King, [the clerk] readeth it to the Jury." Sir Thomas Smith, writing in 1565, speaks in a similar vein ("first is read the examination, which the Justice of peace doeth give in"). ${ }^{316}$

I have been unable to trace a regular practice of this character for the eighteenth century, especially in the Ryder years, either at the Old Bailey or at assizes. ${ }^{317}$ Our sources do not suggest any immediately obvious reason for the declining use of the pretrial deposition. We may hazard as a guess that experience revealed that the depositions were ordinarily surplusage. The deponents had to be in court anyhow, because the Marian committal act, under whose authority the depositions were produced and certified to the court, also required the JP to bind over for trial both the accused and anybody else who could "declare anything material to prove the ... Felony" against him. ${ }^{318}$ The depositions continued to be available for impeaching, and otherwise in exceptional circumstances,

${ }^{313}$ E.g., Elizabeth Ellis, OBSP (Apr./May 1756, \#179), at 162, 163; Ryder Notebook, supra note 19, at 54 (only Ryder's report discloses that "she was carried before Lord Mayor's clerk, to whom she confessed").

3142 \& 3 Phil. \& M., ch. 10 (1555).

s1s T.W., The Clerk of Assize 14 (London 1660) [hereafter cited as Clerk of Assize]. The last edition of the manual, dated 1682 , perpetuates this passage with an important qualification: "he readeth it ... if the Evidence [i.e., the witness giving oral evidence] falter in his Testimony to refresh his memory." [ANON.], The Office of THE Clerk of Assize 48 (London 1682 ed.). This qualification does not appear in the intermediate version of the work, published a few years earlier. [ANon.], The Office of the Clerk of Assize 15 (London 1676 ed.).

318 T. Smith, De Republica Anglorum 99 (L. Alston ed. 1906) (1st ed. London 1583, written 1565) [hereafter cited as T. SMITH, DE REPUBLICA].

s17 The depositions were not systematically preserved at this time, although occasional exemplars survive in the sessions files in the Middlesex and Corporation of London Record Offices. For instances of the reading of the pretrial confession in our 171-case Old Bailey sample, see Esther Taylor, OBSP (Apr./May 1756, \#187), at 164, 165; William Watts \& James Shilock, OBSP (Apr./May 1756, \#\#213-14), at 171, 172; Ryder Notebook, supra note 19 , at 51.

s1s 2 \& 3 Phil. \& M., ch. 10 (1555). 
even after they ceased to be regularly read. If the practice of regular reading turned out to be duplicative, it may have been abandoned simply in keeping with the overriding value of dispatch.

Another way in which the JP might get the results of an investigation before the trial jury was to show up in court and exercise a forensic role, describing his inquiries and testifying about the circumstances of any confession. This practice may always have been relatively exceptional. Scattered instances of such active courtroom prosecutorial work have been documented for the seventeenth century. ${ }^{319}$ For the first half of the eighteenth century, examples are not hard to find in the OBSP. Some OBSP reports for the 1730s and 1740s disclose Sir Thomas de Veil, the Fieldings' predecessor as the court JP for Middlesex, speaking at Old Bailey trials about the circumstances of his pretrial investigations. ${ }^{320} \mathrm{He}$ may, however, have been sitting on the bench as one of the supernumerary trial commissioners discussed above; ${ }^{321}$ his reported statements appear sufficiently limited that they may have been spontaneous interjections.

By the Ryder years the JPs appear infrequently at trial. John Fielding, for example, does not appear in person in the Old Bailey trials chronicled in the Ryder sources. Rather, the standard means of evidencing a pretrial confession to the jury was to have two or more witnesses who had been present at the pretrial examination testify to what the accused said before the JP. Usually these witnesses were persons otherwise involved as prosecution witnesses-victims, witnesses to the crime, pursuers, pawnbrokers.

We must not allow these changing patterns of proving pretrial confessions to obscure the basic point, which is that this legal system placed real emphasis on generating pretrial confessions and having them proved up at jury trial. These confessions greatly accelerated trial, for then as now there could scarcely have been more persuasive evidence than the well-proven admission against interest. The prominence of confession evidence appears natural enough in a legal system that was long accustomed to having the accused as a testimonial resource at trial. Nevertheless, I shall have occasion to point out in the concluding part of this article that,

310 J. LAngbein, supra note 120, at 45-54; A. Macrarlane, The Justice AND the Mare's Ale: LaW AND Disorder in Seventeenth-Century England (1981).

s30 James Hanns, OBSP (Sept. 1743, \#379), at 221; Alexander Asslack \& John Lowdon, OBSP (Feb. 1742, \#\#1-2), at 44; James Scott \& Francis Macquineys, OBSP (June 1736, \#\#5-6), at 131, 132.

${ }^{321}$ See supra notes $\mathbf{1 2 0 - 2 1}$ and accompanying text. I take this suggestion from John Beattie. 
despite the frequency of pretrial confessions, the position of the accused in trial procedure was changing in the Ryder years in ways that foreshadow his declining importance in the developed adversary system of the nineteenth century.

\section{The Crown Witness}

The Hogarth picture that sets the scene for the downfall of the criminous "idle apprentice" in a pretrial examination before the sitting alderman portrays the villain being doomed through the most characteristic prosecutorial device of the contemporary magistracy. As Hogarth's caption tells it, he is "Impeached by his Accomplice." ${ }^{322}$ An accomplice-a confederate in crime who has been shown in the previous plate being captured along with the idle apprentice-is depicted being admitted as the crown witness. He is swearing (center left) to a confession in which he implicates the idle apprentice. The alderman's clerk (far right) is transcribing the confession. The robed alderman averts his anguished gaze from the sight of his erstwhile fellow apprentice, shown helpless and kneeling to beg mercy. His doom will be sealed when the crown witness repeats the confession at the trial of the idle apprentice at the next sessions of the Old Bailey. The crown witness will then go free, excused from prosecution for his own crime in exchange for the testimony that convicts the idle apprentice.

In choosing the crown witness as the motif for his story of a villain's downfall, Hogarth exhibits his celebrated knack for discerning dramatic potential in the detail of contemporary London life. The crown witness system was an endemic feature of criminal justice at the Old Bailey. Crown witness cases occurred in all four of Dudley Ryder's sessions. ${ }^{323}$ And there is a Hogarthian quality to the story of betraying and being betrayed that seemed to play itself out so recurrently in the life cycle of London's hardened or "professional" criminals.

Both Saunders Welch and John Fielding touched on this cycle of betrayal in pamphlet literature of the 1750s. Gang

${ }^{323}$ See supra text accompanying note 301 . (I wish to acknowledge the kindness of Peter Linebaugh, who first drew to my attention Hogarth's use of the accomplice motif.)

s2s See the following examples discussed in text. April/May 1756: Charles Cane \& Thomas Williams, infra text accompanying notes 328-53. October 1755: Edward Lambeth \& George Marsh, infra text accompanying notes 391-92; Abraham Davis et al., infra text accompanying note 518. April 1755: William Richardson, infra text accompanying notes 39394; Francis Pryer \& John West, infra text accompanying notes 328-36; Elizabeth Beer \& Thomas Metcalp, infra text accompanying notes 341-43. October 1754: Lionel Reculus, infra text accompanying notes $337-39$. 
crimes-robberies and other thefts committed by groups of criminals-were the offenses that most tested the primitive law enforcement capacity of the day. "These gangs have been as constantly broke as they have been got together," Welch writes, "[b]ut to effect this benefit to the Public, it has unhappily been necessary to admit one or more of these villains as evidences . . ." "324 (This expression, to admit an accomplice "an evidence" or "the evidence," was the standard term to describe making him the crown witness.) The purpose of admitting one of the gang as the crown witness, Welch explains, is to get him to identify "the rest, and their lurking-places, [as well] as by a discovery of the manner of the robberies to procure prosecutions, and legal evidences to bring them to justice." ${ }^{325}$ In his Plan for Preventing Robberies within Twenty Miles of London, published in the main Ryder year, 1755, Fielding observes that after convicting his confederates, the crown witness "constantly returns to his former course." "Indeed," Fielding continues, "after a man has appeared at the Old Bailey as an evidence, he does not, when he is discharged, find a very easy admission among the industrious part of society; and the motive of his turning evidence being rather the fear of death than remorse for his guilt, there is very little hope of reformation . . ." ${ }^{328}$ In the same vein Welch adds:

These evidences, as soon as their accomplices are convicted, are discharged, and with this addition of infamy are turned into the streets to remain the contempt and terror of society. This sort of reception from the Public never fails to induce the unhappy criminal to endeavor to raise a fresh gang . . . . He soon finds proper associates; and there hardly passes a [sessions of the Old Bailey] when one or more are not convicted, who perhaps the preceding [sessions] were evidences. ${ }^{327}$

32، S. WeLch, A Letter upon the Subject of Robberies, Wrote in the Year 1753, in A Proposal to Render Effectual a Plan to Remove the Nuisance of Common Prostitutes pRom the Streets of This Metropolis 61 (London 1758) [hereafter cited as S. Welch, Proposal].

32 Id.

326 J. Fiblding, Plan, supra note 234, at 11.

317 S. WrLCh, Proposal, supra note 324, at 61-62. Both Welch and Fielding thought the system would be improved if the crown witness were transported rather than released. Id. at 62; J. FizLding, Plan, supra note 234, at 11-12. Both were uncomfortable that, in Welch's phrase, the crown witness was usually "the most notorious villain." S. WeLch, Proposal, supra note 324, at 62; J. Firlding, Plan, supra note 234, at 11 ("commonly the greatest rogue in the gang turns evidence").

One difficulty with the suggestion that the crown witness be transported is that he had HeinOnline -- 50 U. Chi. L. Rev. 851983 


\section{A. The Career of Charles Cane}

This cycle of betrayal can be seen in the Ryder sources in the career of Charles Cane, who appeared as a crown witness in April 1755 and was prosecuted to his death the following April at Ryder's last sessions. In the trials that resulted from the career of this small-time crook we see some of the main attributes of the crown witness system. Although irresistibly convenient to the hardpressed urban magistracy, the crown witness procedure had grievous shortcomings. These shortcomings loomed large among the factors that induced Anglo-American criminal procedure to take its fatal turn in the later eighteenth century toward the law of criminal evidence and the lawyerization of the trial.

Cane was twenty years old in June 1756 when he was hanged at Tyburn. ${ }^{328}$ Hence, he would have been eighteen or nineteen in March 1755 when he had his first major brush with the law in the affair that led to his becoming a crown witness in the April 1755 sessions. We have both the Ryder notebook and the OBSP from which to reconstruct the events. ${ }^{329}$ Cane had fallen in with a gang that engaged in shoptheft and pickpocketing; his colleagues were Francis Pryer, John West, and Randolph Banks. On March 12, 1755 , the gang spotted a shop and dwelling house in Holborn momentarily untended. They took a quantity of coats, frocks, and other cloth goods, later valued at upwards of seven pounds, and fenced them that evening for less than three pounds at a house in the notorious Black Boy Alley. ${ }^{330}$ For whatever reason; Cane lingered at the house (as did West) and was present when Saunders Welch (still serving as high constable of Holborn, a few weeks

not been convicted of the offense he confessed; had he been, he would have been-as a convict-disqualified to testify. See 2 W. Hawkins, supra note 157, ch. 46, § 18, at 432 .

${ }^{328}$ [J. Taylor], The Ordinary of Newgate's Account [For] 28Th June, 1756, at 41 (London 1756) [hereafter cited as Ordinary's AccounT]. Regarding these sources, which were produced by the clergymen who attended the convicts awaiting execution, see Linebaugh, The Ordinary of Newgate and His Account, in CockBURn EsSAYs, supra note 146, at 246, 246-69.

According to the Ordinary who ministered to Cane on death row, Cane was born in 1736, the son of a plasterer. His father sent him to learn the trade at age eleven, hence about 1747. Sometime shortly thereafter a gentleman induced the father to let the boy go into service for an interval of two years. When the term expired and Cane was released to resume learning the trade, "[h]e had contracted a habit of idleness" from which he did not recover. Ordinary's AccounT, supra, at 42 . He fell in with bad company in London, began his career as a pickpocket, and then advanced to shoptheft.

329 Francis Pryer, John West \& Edward Wright, OBSP (Apr. 1755, \#179-81), at 163; Ryder Notebook, supra note 19, at 22; John West \& Winifred Farrel, OBSP (Apr. 1755, \#181A), at 168; Ryder Notebook, supra note 19, at 25.

${ }^{330}$ Regarding Black Boy Alley, see 2 L. RabziNowicz, supra note 49, at 328. 
before he was elevated to the Middlesex magistracy) descended upon the establishment with a force of constables and troops. Testifying at the April trial of Pryer and West, one of the constables, Henry Flanergen, explained: "We did not go there upon the account of these goods [that is, those stolen by Cane's gang], we had another information given us . . ." ${ }^{331}$ Cane, however, thought the raiding party had come in consequence of his shoptheft. He promptly "asked $\mathrm{Mr}$ Welch if he could be admitted an evidence," ${ }^{32}$ and told where in the house to find the stolen goods just fenced. Cane also implicated the other three gang members. West was seized in the house; Pryer was captured later by Flanergen and another constable, aided by Cane and directed by John Fielding; Banks remained at large at the time of the April trials. ${ }^{333}$

1. The Crown Witness Competition. At the trial of Pryer and West, Cane appeared as crown witness. He recounted the details of the shoptheft, the subsequent fencing of the goods, and the capture by Welch's force. Next, the constable, Flanergen, gave the testimony previously discussed; ${ }^{334}$ he continued on to narrate a devastating piece of information. When Flanergen captured Pryer and carried him before Fielding, Pryer asked to be admitted as the crown witness: "he would have made a discovery, if Mr. Fielding

ss1 OBSP (Apr. 1755, \#\#179-80), at 167. A watchman, Luke Martin, testified to having observed West carrying a cheese into the house, upon which Martin "went and told Mr. Welch of it." Id. This may have inspired the search. Stealing cheese was in West's line of work. At the previous sessions of the Old Bailey, West had appeared as the crown witness in a prosecution of one William Banks for the theft of two Cheshire cheeses and 56 pounds of butter from a shop. The goods were valued at above two pounds, well above the five-shilling ceiling for benefit of clergy in shoplifting. The victim testified that "about a week after [the theft] I saw advertisement of such goods in justice Fielding's paper; I went there, and found one John West was turned evidence; there was also the prisoner; West charged the prisoner as [the] one that stole the goods, the prisoner desired the justice to admit him to be the witness; he denied having any hand in taking them [the goods in question], but owned to other robberies." OBSP (Feb./Mar. 1755, \#99), at 85. Banks was convicted, although the jury downvalued the goods to four shillings 10 pence and he was transported. $I d$. This sort of competition to become the crown witness is discussed infra text accompanying notes 33542. We cannot tell whether the William Banks convicted in this case was related to the Randolph Banks who continued with West, Pryer, and Cane until the arrest of West and Pryer. He was a fugitive at the time of the trial of West and Pryer; Cane prosecuted him in January 1756, see infra note 333.

${ }^{332}$ OBSP (Apr. 1755), at 167.

sss Id.; Ryder Notebook, supra note 19, at 24. Ryder adds that Flanergen testified that Cane "told several places where [Pryer] might be found," and that Fielding sent Flanergen, Cane, and one Gee "to find him. We met him afterwards in the street." Id.

Cane prosecuted Banks in the January 1756 sessions. OBSP (Jan. 1756, \#80), at 78. Banks was convicted but the jury downcharged (guilty of theft, not in the shop), and he was transported.

sst See supra text accompanying note 331 . 
would have taken it; [Fielding] told him if he could bring more to light than Cain [sic], he would admit him; he examined him, and it came much to the same of what Cain had said."33s Pryer and West "said nothing in their defense"s3s and were convicted and sentenced to death (for theft from a dwelling house above the nonclergyable amount).

Pryer's damning admission, made in an effort to compete with Cane for Fielding's life-or-death grant of nonprosecution, was not an isolated event. Rather, the standard practice of the day was to employ evidence resulting from such a competition against those who lost it. At Ryder's first sessions in October 1754 Lionel Reculus was tried for stealing a silver tankard from a dwelling house. The pawnbroker ${ }^{337}$ to whom he fenced it, and who attended at Fielding's when Reculus was brought there, testified that Reculus "attempted to impeach one Gentery, upon which Gentery was taken up; but did not say Gentery was concerned in this, but in other robberies. Gentery wanted to be admitted an evidence, but they neither of them would make an ample confession, so the justice said they should both be tried." "338 Reculus was convicted of theft from a dwelling house above the nonclergyable amount and sentenced to death. The sentence was later commuted and he was transported. ${ }^{338}$ Gentery was convicted of an unrelated offense at the same sessions, in part on the evidence of an unrelated crown witness, and transported. ${ }^{340}$

In the April 1755 sessions at which the Cane/Pryer competition was put in evidence, another of these crown-witness competition cases was tried with Ryder presiding. Elizabeth Beer and Thomas Metcalp were prosecuted for housebreaking on the testimony of the crown witness, William Watts, who had committed the break-in with them. Sir Samuel Gore, an active Middlesex JP, had conducted the pretrial investigation. One of the arresting officers testified against Metcalp that Beer told Gore that "she

336 OBSP (Apr. 1755), at 167.

336 Id. at 168 .

${ }^{337}$ OBSP (Oct. 1754, \#469A), at 306. The person to whom Reculus sold the tankard is not expressly identified as a pawnbroker. He testified, however, that "the prisoner came to me and asked me if I would buy a bit of old plate." Id. at 307.

sss Id. at 307 .

s30 Id. at 308,341 (sentence). We reckon the commutation from S. Janssen, supra note 168.

340 OBSP (Oct. 1754, \#486), at 312,313. We infer that one Benjamin Harper testified as a crown witness, as he "went to the justice Fielding, there the prisoner [Gentery] had made an information against me for several things." Id. at 312. The victim's testimony that "Irish Ben [Harper] turned evidence," id., strengthens this inference. 
wanted to be admitted an evidence, and said she could discover more than Watts could." "341 Watts testified that when Metcalp was brought before Gore, "he swore bitterly because he did not make his information before I made mine, because he was taken up the over-night and did not own it."342 The two accused were convicted of clergyable grand larceny and transported..$^{343}$

I shall return to the subject of these crown-witness competition cases below, when discussing the relationship between the crown witness system and the rise of the confession rule, one of the earliest ornaments of the modern law of evidence. We catch a last glimpse of these competitions in our sources in the prosecution of Charles Cane the following year.

2. The Fall of Cane. Cane followed the script for the destruction of crown witnesses set forth in the pamphlets by Saunders Welch and John Fielding previously quoted. Released after convicting Pryer and West, he found "a fresh gang"s44 and returned to shoplifting. Cane's new colleagues included William Cole, who turned crown witness against him, and Thomas Williams. In February and March of 1756 they were on a spree of shoptheft. ${ }^{345}$ According to the trial testimony of one of their victims, a haberdasher named Reeve from whose shop they stole, Fielding already "had some suspicion of . . . Cane being at the head of" the gang when Reeve reported the crime to Fielding. ${ }^{346}$ Underworld inquiries seem to have been made by one of Fielding's minions ("a man belonging to New prison" who told Reeve some days later that "he thought if Cole could be taken he would squeak"). ${ }^{347}$ The OBSP report suggests that Cole was captured with or shortly before Cane and Williams and that all three were before Justice St. Lawrence (another of the active Middlesex JPs) when Reeve was summoned there. Reeve testified that St. Lawrence "was about to admit [Cane] an evidence against Cole," and in that connection Cane there "acknowledged he was concerned with the other prisoner and Cole in robbing me." 348 We are not told how Cane lost the compe-

34 OBSP (Apr. 1755, \#\#187-88), at 173, 175; Ryder Notebook, supra note 19, at 30, 31.

s43 OBSP (Apr. 1755), at 174; Ryder Notebook, supra note 19, at 31.

s4s OBSP (Apr. 1755), at 176, 184; Ryder Notebook, supra note 19, at 32.

244 S. WELCH, Proposal, supra note 324, at 62.

sts OBSP (Apr./May 1756, \#\#200-01, 200A, 202), at 167, 168, 169; Ryder Notebook, supra note 19 , at 45,46 .

ste OBSP (Apr./May 1756), at 167.

267 Id.

s48 Id. at 168. 
tition. Cole testified that "the justice made me evidence, because I was the first that confessed." 349

The Middlesex jury convicted Cane and Williams of the theft from Reeve but downvalued the goods to make the offense noncapital. Cane was thereupon tried immediately again, this time alone, to the same jury, for another shoptheft-of fifteen pounds worth of silk stockings from the shop of Thomas Tolley, committed a couple of weeks before the crime against Reeve. Cole testified that he and Cane committed the theft. Tolley testified that as soon as the crime occurred "I went and told justice Fielding the case, who advised me to put it in the papers, with five guineas reward, which I did." ${ }^{350}$ Suspecting Cane, Fielding ordered his arrest and sent for Tolley. Doubtless under Fielding's direction, Tolley tried inducing Cane to turn crown witness again, telling him that if he "would own it, I would get him to be admitted an evidence if possible and likewise give him two guineas."3si Cane would not confess and had to be released for want of evidence. Cane was rearrested when Cole turned crown witness on him as previously described; according to Tolley, the doomed Cane thereafter gratuitously confessed the crime to Tolley when Tolley visited him in pretrial detention. The OBSP report states that Cane "had nothing to say in his defense." "352 The jury convicted him of the shoptheft as charged, which was above the nonclergyable amount and hence capital.

s20 Id.

sso Id. The text of the advertisement reads:

Feloniously taken out of the Shop of Thomas Tolley, in the Strand, two Dozen and odd Pair of Black Silk Stockings, marked T. under the Whelt and with red or white Paint in the Feet, some are knit ribbed, and others Wove. If such Stockings are offered to pawn or Sale, stop them and the Party, and you shall receive Five Guineas Reward on Conviction, from John Fielding, Esq.

Public Advertiser, Feb. 9, 1756, at 2, col. 2. Misfiled in the London (rather than Middlesex) sessions files for the April/May 1756 sessions is a document dated March 16 containing the prosecutor's information reciting the shoptheft, sworn before Saunders Welch, and on the same page, the information of Cole:

Who being upon Oath says that the Evening before the last general Fast Charles Cane, William Roberts, and himself Stole of a Shop between Durham Yard and King's Wharf in the Strand twenty-four pair of Silk Stockings, which said Stockings this Informant in company with Cane and Roberts Sold to one Alexander Abrahams now present for Fifty-six Shillings at his House near Hounsditch, the said Abrahams well knowing the same to be Stolen.

CLRO, Sessions Papers (May 1756 sessions), loose document. Cole signed by mark, also before Welch on March 16. Cole and Richardson testified as crown witnesses against Abrahams, who was convicted of receiving stolen property and transported. OBSP (Apr./ May 1756, \#212), at 171.

ssi OBSP (Apr./May 1756), at 168.

ss2 Id. at 169. 
Awaiting execution, Cane told the clergyman who ministered to him that he had expected "nothing less than hanging to be his fate at last, but not of the evil day's coming so soon."

\section{B. The Juridical Basis}

The impression that we gain from Old Bailey trials of the 1750 s is that the crown witness system was practically the only resort of the London authorities in dealing with gang crimes. It is true that such cases constituted only a fraction of the caseload. Single offenders predominated, and in any event most cases involved offenders caught in the act, or in pursuit, or with the goods. But for the more recondite crimes perpetrated by groups of offenders, the authorities seem to have been utterly dependent on the crown witness system. The two Fielding brothers and Saunders Welch say as much in their tracts, ${ }^{354}$ and our sources bear them out.

The practical importance of the crown witness system is not reflected in the formal law of the Ryder years. The system we have seen in operation lacked a statutory basis, and since the usage had not been tested in case law, it is difficult to speak of there having been a common law basis in the ordinary sense. Nevertheless, there was an analogy in a defunct procedure that helped legitimate the crown witness system. This was the law of approvement, which had originated as a branch of the medieval appeal of felony.

Lord Mansfield called approvement the "analogy to which this [crown witness] practice has been adopted."'sss An appealed (or in the later procedure, an indicted) person could turn approver by tendering a guilty plea, that is, confessing the whole charge, but offering to appeal his accomplices (in the later procedure, to testify against them at jury trial). If he succeeded in procuring the conviction of his accomplices, judgment was respited on his guilty plea and a pardon was issued him. If he failed, he was sentenced to death on his guilty plea. The eighteenth-century treatises carried accounts of approvement derived from the medieval precedents, ${ }^{356}$ but the procedure was acknowledged to have fallen into complete

ss3 ORDINARY's AccounT, supra note 328, at 43.

sst H. Fielding, EnquiRY, supra note 186, at 111, quoted supra text accompanying note 239; J. Fielding, Plan, supra note 234, at 10-11; S. Welch, Proposal, supra note 324, at 61, quoted supra text accompanying note 324 .

sss Rex v. Rudd, 1 Leach 115, 119, 168 Eng. Rep. 160, 162 (K.B. 1775) (Mansfield, C.J.), also reported in 1 Cowp. 331, 335, 98 Eng. Rep. 1114, 1116 (K.B. 1775).

sss See, e.g., 2 M. HALE, supra note 241 , at 225-35; 2 W. HAwKINs, supra note 157 , ch. 24, at 204-09. 
desuetude. The hazard of the guilty plea was too great.

The crown witness procedure recognized the new reality of the rise of prosecutorial management by justices of the peace. The decisive step in the crown witness system was taken at the pretrial level, when the magistrate made his grant of nonprosecution. The crown witness remained unindicted throughout. By contrast, the approver had, so to speak, a noose around his neck; he was not only indicted, he had pleaded guilty, and he would be executed if his approvement miscarried for any reason. The crown witness had in practice only a "best efforts" responsibility for convicting his confederates. Henry Fielding wrote in 1751 that once the crown witness "hath impeached his Companions, and is admitted an Evidence against them, whatever be the Fate of his Evidence, [he] always goes free. ... [I]t is true, he hath no positive Title [in the sense of entitlement to nonprosecution] ... But the Practice is as I mention, and I do not remember any Instance to the contrary."357

The coinage of approvement was pardon; the coinage of the crown witness system was nonprosecution. Technically, no statute or rule of common law would have prevented John Fielding from reneging on his promise of nonprosecution in, say, the case of William Cole. ${ }^{358}$ But word would have traveled through the London underworld in a flash, and the embattled London magistracy would have lost for the future its main device for gathering evidence in the most worrisome cases. Accordingly, what made the crown witness system workable was the mutual perception of interest on the part of magistrates and criminals that a magistrate's promise of nonprosecution in a particular case would be honored.

When the superior courts finally had occasion to pass upon the crown witness system in 1775, Fielding-far from reneging-was nominally aligned in support of the criminal. The facts in the wellknown $^{359}$ case of Rex $v$. Rudd ${ }^{360}$ were these: Mrs. Rudd had been concerned in several major forgeries with two brothers, Robert and Daniel Perreau. Mrs. Rudd confessed to Fielding that she had had a subordinate role in one of the forgeries; Fielding, joined by two other JPs, "admitted her in the character of an accomplice, a gen-

ssz H. Fizlding, EnquiRy, supra note 186, at 115.

sse See supra notes 344-53 and accompanying text.

sss 2 L. RAdzINowicz, supra note 49 , at 40 n.19; 2 J.H. WIGMoRE, supra note $76, \S 818$, at $131, \S 819$, at $133, \S 834$, at 161 .

${ }_{380} 1$ Leach 115, 168 Eng. Rep. 160 (K.B. 1775). 
eral witness for the Crown."381 At the trial of Robert Perreau, the prosecuting victim testified "that Mrs. Rudd had confessed to him, that she was guilty of forging the bond [in question] and that Robert Perreau was innocent." victed Perreau, the Old Bailey judges presiding at the trial ordered Mrs. Rudd committed to jail to be prosecuted for the forgery. "Under these circumstances she obtained a Habeas Corpus to the Court of the King's Bench, with a view to be admitted to bail 99368

The main theory under which Mrs. Rudd sought to be bailed was stated in the following terms by Lord Mansfield, who gave the judgment in the case:

[I]f, in a proper case, an application be made to this Court by an accomplice to be bailed; that is, in the case of a person properly within the usage [of the crown witness system], and who has fully complied with the requisite conditions, I should have no difficulty in bailing him, in order that he might apply for the King's pardon. ${ }^{364}$

In other words, were a crown witness to be double-crossed, were the authorities to renege on a promise of nonprosecution after taking advantage of a good-faith performance by the accomplice, King's Bench would stay the prosecution, grant bail, and procure the grant of executive clemency to terminate the case.

In this special sense the pardon power could be said to underlie the crown witness system. If, said Mansfield, the crown witness were to "act fairly and openly, and discover the whole truth, though he is not entitled of right to a pardon, yet the usage, the lenity, and the practice of the Court is, to stop the prosecution against him; he having an equitable title to a recommendation for the King's mercy."36s This marvelous phrase, often thereafter quoted-_equitable title" to a pardon-has had an unfortunate consequence for legal historical understanding of the crown witness system. By emphasizing a connection between pardon and crown witness, a connection so exceptional that it arose only in the event of a breakdown in the crown witness bargain, Mansfield's formulation obscured the central mechanism of the crown witness system,

soI Id. at 116, 168 Eng. Rep. at 161.

${ }^{302}$ Id.

sss Id.

ses Id. at 121, 168 Eng. Rep. at 163.

${ }^{365}$ Id. at 119, 168 Eng. Repeift 162 
which was nonprosecution rather than pardon. Mansfield's language misled Radzinowicz, for example, into treating "[t]he practice of granting a pardon to [crown witnesses] . . . as a major incentive. . . on which much reliance was placed."368 In his History Radzinowicz subordinates the crown witness system as a nonstatutory imitation of a group of seventeenth- and eighteenth-century statutes that offered formal pardons to certain classes of fugitive offenders on condition that they surrender, confess themselves guilty, and procure the capture and conviction of their colleagues, usually to the minimum of two. ${ }^{387}$ These statutes were, however, failures, and Radzinowicz was unable to uncover evidence of them ever having been used. ${ }^{368}$ Radzinowicz correctly observed that these statutes share with the crown witness system the effort to encourage accomplice prosecutions. ${ }^{368}$ But they differ both in the mechanism (pardon versus nonprosecution) and in the result: The statutes were virtual dead letter, whereas the crown witness system was the mainstay of gang-crime prosecution.

The crown witness system operated in routine cases with no exercise of the pardon power. Accomplices like Cane, Watts, and Cole simply were released after they testified. Mansfield seems to deny this in a passage in the Rudd case that further misled Radzinowicz (who quoted some of $\mathrm{it}^{370}$ ):

[N]o authority is given to a Justice of the Peace to pardon an offender, and to tell him that he shall be a witness against others. The accomplice is not assured of his pardon; . . . and it depends on the title he has from his behavior, whether he shall be pardoned or executed. A Justice has no authority to select whom he pleases to pardon or prosecute . . . .

Mansfield was quite correct to say that the JP had no power to pardon the crown witness, since as we have been emphasizing what the JP had to offer was nonprosecution and not pardon. Mansfield was also technically correct, but practically misleading, to say that

ses 2 L. RADZINowicz, supra note 49 , at 44 .

s67 Id. at $40-45$.

sss One instance of seeming use is recorded in a pamphlet account of ThE LIFE of Tho[mas] Neaves, the Noted Street-Robber (London, n.d. [ca. 1729]) [hereafter cited as Neaves PamphLet]. Neaves prosecuted six confederates to death at the Old Bailey in May 1728. "At the Sessions which began the 17th of July, Neaves pleaded his Majesty's Pardon, and was discharged accordingly ...."Id. at 24. The OBSP confirm that Neaves testified, OBSP (May 1728), at 7, and that he pleaded a pardon, OBSP (July 1728), at 8.

ses 2 L. RADzINowicz, supra note 49 , at $40-41$.

s7o Id. at 40 n.19.

s71 1 Leach at 121, 168 Eng. Rep. at 163. 
the JP had no absolute power to foreclose prosecution of the crown witness, as the proceedings in Rudd demonstrated. Mansfield was saying that when Fielding and his fellow JPs admitted Mrs. Rudd as a crown witness, they did not estop the Old Bailey judges from forming the view (which Mansfield and the rest of the King's Bench endorsed in rejecting Mrs. Rudd's habeas application), that the promise of nonprosecution should not be honored on account of the deceitful behavior of the crown witness herself. Accordingly, King's Bench allowed her to be prosecuted (she was, but the jury acquitted her). ${ }^{372}$ Mansfield was, therefore, correct in insisting that Fielding's affidavit to King's Bench certifying that Mrs. Rudd had been admitted a crown witness did not prevent her from being prosecuted when her deceit was disclosed. As a general characterization of the crown witness system, however, it was flatly wrong for Mansfield to say that the JP "has no authority to select whom he pleases to . . . prosecute," ${ }^{\text {"373 }}$ for this selection was exactly how the system worked.

The JP's practical control of nonprosecution of the crown witness depended on the cooperation of other JPs and, indeed, of private prosecutors, since the theory of English criminal procedure was (and to some extent still is ${ }^{374}$ ) that any citizen may prosecute for the crown. But in practice the JPs seem not to have interfered with each other's decisions to designate accomplices as crown witnesses. As for private complainants, the grand jury was not likely to find a true bill if it meant overruling a JP's decision not to prefer a bill of indictment against an accomplice-turned-crown-witness. (We might note in this connection the tradition that the JPs sat on eighteenth-century grand juries. ${ }^{375}$ )

The crown witness system was a creature of practice, and there is no reason to think that it operated with perfection. Cases

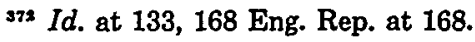

s7s Id. at 121, 168 Eng. Rep. at 163.

374 R. Jackson, The Machinery of Justice in England 155 (6th ed. 1972). See generally Williams, Prosecution, Discretion and the Accountability of the Police, in CRIMr, Criminology and Public Policy: Essays in Honour of Sir Leon Radzinowicz 161-95 (R. Hood ed. 1974). For discussion of a 1972 case that renewed debate in England on the proper scope of private prosecution, see Langbein, Controlling Prosecutorial Discretion in Germany, 41 U. ChI. L. Rev. 439, 441 n.2 (1974).

${ }^{375}$ Ryder preserves incidental mention of this practice in his assize diary in the course of describing dining arrangements. At Essex assizes in 1755, he noted: "I invited the Justices of Peace to dinner this day, but had but few by reason of the Grand Jury dining with the sheriff." Ryder Assize Diary, supra note 21, at 21. At Kent assizes the next week: "The sheriff did not entertain the Grand Jury, so that we had about 22 of the Justices . . . ." Id. at

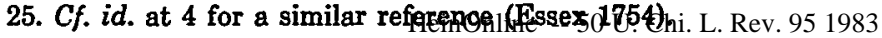


must have occurred in which JPs acted at cross purposes, accidentally or otherwise. Mansfield must have had something in mind when he said in his opinion in Rudd that the King's Bench already had developed the procedure of stopping the prosecution of an unfairly double-crossed crown witness in order to procure him a pardon. ${ }^{376}$ The present point is that such cases occurred at the outer margin of the crown witness system, with such rarity that we can identify none up to the time of the proceedings in Rudd, either in the sources cited in that case or in sources otherwise thus far brought to light. The daily reality of the crown witness system was precisely the opposite of the theoretical point that Mansfield enshrined in the Rudd case. The JP may have lacked absolute authority to grant immunity from prosecution to a crown witness, but he had total command of that power in actual practice. Indeed, the only purpose of the "equitable title" to pardon that Mansfield endorsed in the Rudd case was to protect (and thereby to promote) the reliance of accomplices upon the JP's promise.

\section{Corroboration: The First Rule of Evidence?}

Our modern law of evidence has accustomed us to a trial procedure in which the exclusion of probative information is pervasive. This system, which Europeans find so astonishing, requires us to conceal various types of probative but hard-to-evaluate evidence on account of the supposed inability of the jury to appreciate properly its difficulty. In the previous article in which I described Old Bailey trials of the period up to 1735, I emphasized that the evidentiary rules that later came to distinguish Anglo-American trial procedure were scarcely to be observed. ${ }^{377}$ By the Ryder years, the tone of the criminal trial began to change in subtle ways that, in retrospect, appear to us to foreshadow the rise of adversary procedure and the law of evidence later in the century. These developments are discussed in the final part of this article. In the present section my purpose is to point out how certain attributes of the crown witness system begat one of the earliest manifestations of what we can later identify as the law of criminal evidence, the corroboration rule.

After William Cole had testified as the crown witness in the two trials of Charles Cane discussed above ${ }^{378}$ and had succeeded in

.378 1 Leach at 119, 168 Eng. Rep. at 162.

s7z Article I, supra note 1, at 300-06.

s7s See supra text accompanying notes 344-53. 
having Cane capitally convicted, Cole still had a good day's work ahead of him. As part of his agreement with Fielding, he prosecuted three further cases. He testified in separate cases against Mary Powell and Alexander Abrahams, indicted for receiving stolen goods from the Cane gang, ${ }^{379}$ and against Richard Munday, not a member of the Cane gang, for a shoptheft committed jointly with Cole. In his trial at the Old Bailey, Munday attempted to impeach Cole's testimony with the following reproach: "He is a very great villain; he will say anything to save his own life."

In principle, Munday was making a powerful argument, whose force has long been acknowledged in the developed law of evidence. A good statement of the policy is Lord Abinger's, from an 1837 precedent: "The danger is that when a man is fixed, and knows that his own guilt is detected, he purchases impunity by falsely accusing others." ${ }^{381}$ The crown witness labored under a material incentive to commit perjury, which greatly affected the reliability of his testimony.

In the case of Richard Munday, the jury convicted him, not in ignorance or disregard of this danger, but because the prosecution satisfied the major safeguard that the common law had encouraged for dealing with the danger, the so-called "corroboration rule" (also known as the "accomplice rule"). Another eyewitness to the shoptheft identified Munday at the trial. ${ }^{382}$ The testimony of Cole, the crown witness, was thereby corroborated through independent evidence.

Wigmore frames the issue of the corroboration rule thus: "May a jury lawfully convict of a crime on the sole testimony of an accomplice in the alleged crime? Or must his single testimony be corroborated by other evidence?"'s83 Limited by his sources (the printed law reports), Wigmore concluded that "not until the end of [the eighteenth] century"384 (when much of the rest of the law of criminal evidence was taking shape) did there come "into acceptance a general practice to discourage a conviction founded solely

370 Mary Powell, OBSP (Apr./May 1756, \#202), at 169 (acquitted); Alexander Abrahams, OBSP (Apr./May 1756, \#212), at 171; see supra note 350.

sso OBSP (Apr./May 1756, \#203), at 169, 170.

sas Regina v. Farler, 8 C. \& P. 106, 108, 173 Eng. Rep. 418, 419 (Worcester assizes 1837), cited in 4 J.H. WIGMore, supra note $76, \S 2057$, at 358, § 2059, at 362.

ss2 OBSP (Apr./May 1756, \#203), at 167. The jury convicted but downvalued the goods, and Munday was transported.

2ss 4 J.H. WIGMORE, supra note 76, § 2056, at 350.

ses Id. at 351. 
upon the testimony of an accomplice uncorroborated."

Understandably, Wigmore had no particular reason to think of extending his research on this question to the nonfiction writings of Henry Fielding. If he had, and if he had understood why Fielding spoke with such authority on crown witness matters, he would have formed a materially different view of the history of the corroboration rule. Wigmore would have concluded that the rule was already in force in 1751 when Fielding published the Enquiry, and in a much stronger version than that which found its way into the law reports of the later 1780 s, where Wigmore picked up the story.

Fielding discussed the corroboration rule in the Enquiry because he was hostile to it and wanted it altered. It is virtually the only subject treated in his chapter on trial procedure ${ }^{386}$ Like many a later Anglo-American official charged with detecting and prosecuting persons responsible for serious crimes, Fielding felt that the courts were hampering his efforts unduly: "for though the Evidence of the Accomplice be ever so positive and explicit, nay ever so connected and probable," Fielding wrote, "still, unless it be corroborated by some other Evidence, it is not sufficient."387 Or again:

Unless therefore the Robbers should be so unfortunate as to be apprehended in the Fact, (a Circumstance which their Numbers, Arms, \&c. renders ordinarily impossible) no such Corroboration can possibly be had; but the Evidence of the Accomplice standing alone and unsupported, the Villain, contrary to the Opinion, and almost direct Knowledge of all present, is triumphantly acquitted, laughs at the Court, scorns the Law, vows Revenge against his Prosecutors, and returns to his Trade with a great Increase of Confidence, and commonly of Cruelty. ${ }^{388}$

This mandatory corroboration rule that Fielding was protesting found expression in a directed verdict standard. When a prosecution case founded upon accomplice testimony was not supported by corroborating evidence, the court dismissed the case without hearing defensive evidence. Fielding objected that "the Evidence of an Accomplice [was being treated as] not sufficient to put the Prisoner on his Defense, but the Jury are directed to ac-

388 Id.

sso H. Fielding, Enquiry, supra note 186, at 111-17 (ch. 9, "Of the Trial and Conviction of Felons").

${ }^{88 z}$ Id. at 111.

288 Id. at 112. 
quit him." ${ }^{889}$ The main reform that Fielding had in mind was that such cases be allowed to reach the jury. "For I intend no more than that such Evidence shall put the Prisoner on his Defense, and oblige him either to controvert the Fact by proving an Alibi, or by some other Circumstance; or to produce some reputable Person [to] his Character." ${ }^{380}$

Conceivably, Henry Fielding misunderstood the corroboration rule in force in his day and misdescribed it in his tract, although this possibility must appear highly unlikely. As the court JP for Middlesex, Fielding had more reason than anyone else in England to know the law governing crown witness testimony. The Ryderperiod sources, dating from a few years after the Enquiry, give us one apparent example of adherence to the corroboration rule and a larger body of practice consistent with it.

In a pair of connected cases in the October 1755 sessions, the OBSP attribute the outcome to the corroboration rule. In the first case, Edward Lambeth, a bargeman, was tried for receiving stolen oats. After reciting the details of the indictment, the OBSP report states in its entirety: "This was upon the single evidence of Samuel Hicks, an accomplice with Welling, who was convicted for stealing the same [goods] last sessions. (See his trial, No. 340.) Acquitted." 391 George Marsh, also charged with receiving stolen grain in an incident a month later, was also acquitted. The report explains: "This was on the single evidence of the aforesaid accomplice. (See as directed in the former trial.)" "392 Use of the term "directed" in this context probably means that the reporter observed the judge to direct the verdict of acquittal, although we cannot exclude the possibility that something quite different was meant, and that readers were being "directed" to the cross-reference mentioned in the previous case.

The corroboration rule seems to figure in the outcomes of other cases in the sources, although the reports do not disclose either the ground of acquittal or the happening of a directed verdict. As it happened, Ryder did not preside in any of the cases arising at

sso Id. at 113.

soo Id. at 116 (emphasis in original).

s21 OBSP (Oct. 1755, \#385), at 340. The language quoted in text is italicized in the OBSP, in order to disclose that it is third-person summary from the reporter rather than verbatim transcription of someone's courtroom declaration. In the case cross-referenced in the quoted text, Thomas Welling, OBSP (Sept. 1755, \#340), at 293, the accused was tried on three separate indictments. The testimony of the crown witness, Hicks, was corroborated by further witnesses, including a JP's clerk reading Welling's pretrial confession.

s92 OBSP (Oct. 1755, \#386), at 340 (italics deleted). 
the four Old Bailey sessions that appear to instance acquittal for want of corroboration, and we know them only from the OBSP reports, which commonly deleted such legal details.

At the April 1755 sessions William Richardson was prosecuted for stealing a pair of plucked ducks from a poulterer's. Several thieves had been involved, and they tossed the ducks away when pursued. The shopkeeper could not identify Richardson, and neither could another witness who had pursued and apprehended him. That left only an accomplice to testify that he and Richardson had stolen the ducks and had been captured fleeing. "[T]hey carried me before justice Withers, and I was admitted an evidence there." 393 The report does not mention any defensive evidence but records simply, "Acquitted." 304 The absence of what the OBSP reports usually call the "prisoner's defense" in a case that is otherwise reported in detail is not conclusive (we have explained why omissions from OBSP reports can virtually never be conclusive), but we incline to infer in this setting that no defense occurred. What may have happened is that Richardson was acquitted on a directed verdict when it became apparent that the crown witness's evidence could not be corroborated. The acquittal of Mary Powell in April 1756 for receiving stolen cloth goods from the Cane gang, mentioned previously, is another such case. Only the ubiquitous William Cole, the crown witness, testified, and the report discloses an acquittal without defensive evidence. ${ }^{385}$

The issue of requiring corroboration for accomplice testimony entered the chain of reported common law precedent in 1788 in Rex v. Atwood \& Robbins, ${ }^{396}$ the case that Wigmore thought originated the practice of discouraging "a conviction founded solely upon the testimony of an accomplice uncorroborated."387 The Ryder-period sources show the practical importance of a corroboration requirement a generation earlier. Henry Fielding was chafing at it in his revealing tract of 1751 . How much earlier the requirement appeared, ${ }^{398}$ and whether it was a consequence of the rise of the court JP for Middlesex and his systematic production of

s9s OBSP (Apr. 1755, \#157), at 149.

sor Id.

398 OBSP (Apr./May 1756, \#202), at 169, mentioned supra text accompanying notes 379-80.

so6 I Leach 464, 168 Eng. Rep. 334 (1788).

3974 J.H. Wigmore, supra note $76, \S 2056$, at 351.

${ }^{328}$ For a likely instance predating Fielding's magistracy, see the case of James Ruggles, John Smith, and Thomas Cheworth, OBSP (Dec. 1744, \#\#93-95), at 48, 49: "There being no other evidence but the accomplices, the prisoners were Acquitted." 
crown-witness testimony, we cannot yet say.

Atwood \& Robbins led Wigmore astray not only regarding the timing of the corroboration rule, but also its substance. In place of the rule of mandatory corroboration that Fielding was protesting in 1751 and that we have seen evidenced in the Ryder sources, Atwood \& Robbins substituted a radical alteration, a rule that would have more than pleased Henry Fielding. Sitting at assizes in Taunton, Buller, J. (author of the influential nisi prius handbook $^{399}$ ) allowed a jury to convict a pair of highway robbers on "the evidence of an accomplice unconfirmed by any other evidence." $"$ Heo respited execution because, he said "a doubt [arose] in my mind respecting the propriety of this conviction," and he therefore "thought it proper to refer [the] case to the consideration of the Twelve Judges"401 - the mechanism for seeking the views of all the judges of the superior courts. ${ }^{402}$ How and when the settled rule of the Ryder period was brought into doubt, we cannot of course say on the basis of the Ryder-period sources. We note that Madan's tract of 1785 presupposes that the rule that Henry Fielding criticized was still in force. ${ }^{403}$ Thomas Leach's edition of Hawkins' Pleas of the Crown, which appeared in 1787, the year before Atwood \& Robbins, contains new text that continues to speak of mandatory corroboration, although Leach uses a term, "credit," that was about to figure in the revision of the rule. "[T]he bare, uncorroborated testimony of an accomplice is not thought of sufficient credit to put a prisoner upon his defense . . . ."404

The Twelve Judges followed Buller. They concluded unanimously that "a conviction supported by [crown witness] testimony alone is perfectly legal"405 — a result flatly contradicting the rule of the Ryder period. They reasoned, Buller reports, that since it had been long settled that accomplices were competent to testify, it followed that any objection to uncorroborated accomplice testimony went to credit-to the weight to be attached to the testimony-and issues of credit were always for the jury. Having thus framed the issue, the result was easy to derive:

399 F. Buller, An Introduction to the Law Relative to Trials at Nisi Prius (1st ed. under Buller's name published London 1772; regarding forerunners, see E. Foss, BIOGRAPHIA JURIDICA, supra note 16, at 137, 138).

1001 Leach at 465, 168 Eng. Rep. at 334.

101 Id.

101 For a short description of the procedure see Baker, supra note 146, at 47-48.

${ }^{103}$ M. MADAN, supra note 49, at 157-72; see particularly id. at 166.

104 This passage is cited in full infra text accompanying note 521.

4051 Leach 465, 168 Eng. Rep. at 334. 
The distinction between the competency and the credit of a witness has long been settled. If a question be made respecting his competency, the decision of that question is the exclusive province of the Judge; but if the ground of the objection go to his credit only, his testimony must be received and left with the Jury, under such directions and observations from the Court as the circumstances of the case may require, to say whether they think it sufficiently credible to guide their decision in the case. ${ }^{406}$

From the standpoint of the developed law of evidence, the weakness in this reasoning is the premise that all evidence not suspect on the ground of credit had to be admitted. That is precisely the path of rule-free evaluation of the proofs from which our law was turning away when it began to concern itself with the question of whether proferred evidence was prejudicial or otherwise unduly hard for the jury to evaluate. A contrary analysis had already been employed five years before Atwood \& Robbins in another sphere. In Rex $v$. Warickshall (1783), ${ }^{407}$ the leading case on the so-called confession rule, the assembled judges of the superior courts agreed unanimously to conclude an issue that they acknowledged to be one of credit. They said that "no credit ought to be given [to a tainted confession] and therefore it is rejected."408 Accordingly, whatever motivated the decision in Atwood \& Robbins was not likely to have been the ground supplied in the opinion.

Atwood \& Robbins recast the corroboration rule in the form it has since retained in English law. ${ }^{409}$ The unreliability of accom-

${ }^{400} 1$ Leach at 465-66, 168 Eng. Rep. at 334-35 (emphasis supplied). Henry Fielding had suggested this reasoning in the Enquiry:

- But surely, if the Evidence of an Accomplice be not sufficient to put the Prisoner on his Defense, but the Jury are directed to acquit him, though he can produce no Evidence on his Behalf, either to prove an Alibi, or to his Character, the Credibility of such Testimony cannot well be said to be left to a Jury. This is virtually to reject the Competency of the Witness: For to say the Law allows him to be sworn, and yet gives no Weight to his Evidence is, I apprehend, a mere Play of Words, and conveys no Idea.

H. Fielding, Enquiry, supra note 186, at 113 (emphasis in original).

4071 Leach 263, 168 Eng. Rep. 234 (1783).

108 Id. at 264, 168 Eng. Rep. at 235.

609 As opposed to American law, where "in nearly half of the jurisdictions . . . a statute has expressly turned this cautionary practice into a rule of law." 4 J.H. Wigmore, supra note $76, \S 2056$, at 356 . Wigmore linked the American development in making the corroboration rule mandatory to the broader phenomenon, discussed supra note 76 , of the elimination of the American trial judge's power to express his "opinion upon the weight of the evidence in a given case. Unless there was a rule of the law of Evidence upon the subject of an accomplice's testimony, [the judge] could not in any case advise [the jury] to refuse to convict upon the uncorroborated testimony of an accomplice." 4 J.H. WIGMORE, supra note 
plice testimony and the utility of corroboration became a matter for the judge to caution the jury according to the circumstances of the particular case. Atwood \& Robbins returned to the jury the power to convict on uncorroborated accomplice testimony. A comparatively inconsequential duty to warn replaced a directed verdict of acquittal. This, the "modern" rule, Wigmore found in the earliest published report. He had no reason to suspect that it represented the repeal of an older and much stricter rule. In the final part of this article, treating the development of trial procedure and the origins of the adversary system, I shall suggest that, despite its short life, the earlier rule-the forgotten directed-verdict rule- may have had some bearing on the future shape of AngloAmerican criminal procedure. ${ }^{110}$

\section{The Confession Rule}

I wish to conclude this discussion of the crown witness system by directing attention to the possibility that it contributed to a development with which it is not ordinarily associated: the appearance of the "confession rule," one of the earliest"11 and still one of the most important rules of evidence.

In the language of the leading case just mentioned, Warickshall, the rule distinguished a pretrial confession that was "free and voluntary" and hence "deserving of the highest credit" from one "forced from the mind by the flattery of hope, or by the torture of fear," to which "no credit ought to be given."112 Wigmore thought that this formulation gave "the modern rule . . . a full and clear expression . . . . From this time on, the history of the doctrine is merely a matter of the narrowness or broadness of the ex-

$76, \S 2056$, at 357 .

110 See infra text accompanying notes 519-21.

111 I have discussed the paucity of rules of evidence into the 1730s in Article 1 , supra note 1 , at 300-06.

Hawkins called a chapter of the second volume of his Pleas of the Crown (published in 1721) "Of Evidence." 2 W. HAwkINS, supra note 157, ch. 46, at 428-39. It covers a miscellany-for example, competency and disqualification; indictment sufficiency; and statutory construction, especially in treason cases. Of the main themes of the modern law, only the hearsay rule is stated recognizably: "[W] hat a Stranger has been heard to say is in Strictness no Manner of Evidence either for or against a Prisoner, not only because it is not upon Oath, but also because the other Side hath no opportunity of a cross Examination." Id. at 431. This formulation is immediately followed, however, by an exception of such breadth that it virtually empties the rule of meaning. Hearsay "shall never be made use of but only by way of Inducement or Illustration of what is properly Evidence." Id. I have reported examples of hearsay in Article I, supra note 1, at 301-02.

4121 Leach at 263-64, 168 Eng. Rep. at 235. 
clusionary rule."413

Wigmore's remark reminds us starkly that the confession rule presaged the future of the Anglo-American law of evidence. It was an "exculsionary rule." Like most of the rest of the remarkable structure that would be erected in the name of the law of evidence over the next decades, the confession rule worked by excluding from the trial jury concededly probative information for fear that the jury lacked the ability to evaluate the reliability of the information properly. However accustomed we have since become to this way of handling criminal adjudication, we must remain aware that it was a recent invention in the day of the precedents Wigmore cites, and one whose origins have yet to be explained.

Wigmore dated the appearance of the confession rule to the period 1775-1785.114 He was baffled by this precocious event, and he was savagely critical of its results in the early nineteenth-century case law-"a general suspicion of all confessions, a prejudice against them as such, and an inclination to repudiate them upon the slightest pretext."415 Although he viewed this judicial hostility to confessions as "sentimental irrationality," 116 he groped to explain it. He speculated that patterns of English social deference underlay the rule. The judges may have been concerned that "halfrespectful and half-stupid" peasants allowed themselves to be intimidated by "social superiors." Wigmore expressed his own bewonderment at this silly thought. "We may believe that rationally a false confession is not to be apprehended from the normal person under certain paltry inducements or meaningless threats; but we have here perhaps a person not to be tested by a normal or rational standard." 412 Thin as this conjecture otherwise was, it seems especially unhelpful on the matter of timing. Social stratification was centuries old, and the further back the more striking. Why then did the judges first appear to become alarmed about it in the reign of George III? ${ }^{418}$

The earliest discussion of something like the confession rule that Wigmore was able to identify occurred in the decade before Warickshall, in dictum in Mansfield's opinion in Rudd (1775), the great case treating the status of the crown witness. Mansfield

42s 2 J.H. WigmoRe, supra note 76, § 819, at 133.

414 Id.

415 Id.

116 Id. $\S 865$, at 221.

427 Id. at 222.

418 Wigmore had some other thoughts on the English judges' disposition to develop the confession rule. Id, at 222-24. 
touched on the matter in a single sentence, simply by way of illustration, in order to contrast the exclusion of a confession with that complete immunity from prosecution that Mrs. Rudd was claiming as her due. He said: "The instance has frequently happened, of persons having made confessions under threats or promises: the consequence as frequently has been, that such examinations and confessions have not been made use of against them on their trial." 418

Mansfield did not say enough about what he had in mind to alert Wigmore to any connection to the crown witness system. Wigmore treated the remark as a lucky piece of dictum, and he did not probe its context. ${ }^{420}$ From the perspective of the Ryder sources, however, the context seems important. We have seen repeatedly how a confession uttered by the loser in the competition to be made the crown witness was used against him, and with devastating effect. These were clear instances of confessions "forced from the mind by the flattery of hope,"421 hence proscribed by the rule in Warickshall. The question for the future, therefore, is when and under what circumstances the attitude toward such evidence changed.

We conclude our discussion of the crown witness system with the observation that, despite its acknowledged importance in gangcrime prosecutions, it confronted the courts with a recurrent class of cases in which there might be great reason to doubt the reliability of the evidence. Both in the original corroboration rule (that is, the directed verdict rule) and in the confession rule, we see the courts responding in the way that later became characteristic of Anglo-American law, and which, when expanded and systematized as the law of evidence, put our trial procedure at such odds with the Continental tradition. The courts tried to devise rules of exclusion. In Part VIII, treating trial procedure, I shall say more about why the courts may have found this approach attractive.

\section{The Reward System and the Macdaniel Scandal}

Quite apart from the crown witness system, concern with the reliability of the evidence in criminal prosecutions was much in the air in the Ryder years. On Ryder's first tour as an assize judge, in August 1754, there broke one of the greatest scandals ever to taint

119 Rudd, 1 Leach at 118, 168 Eng. Rep. at 161.

4202 J.H. Wigmore, supra note $76, \S 819$, at 133 .

${ }^{421}$ Warickshall, 1 Leach at 263-64, 168 Eng. Rep. at 235, quoted supra text accompanying note 412. 
the administration of criminal justice in England, the Macdaniel affair. It came to light that a gang had been prosecuting innocent men to their deaths in order to collect reward money.

The Macdaniel scandal is reasonably well known in the legal historical literature. It led to trials that are preserved in the State Trials, and it produced a major precedent on the substantive question of whether murder can be committed by perjury when the perjury results in the conviction and execution of an innocent man on a capital charge. ${ }^{422}$ Radzinowicz pointed to the Macdaniel affair as one of the earliest events that gave English opinion cause to worry about the patchwork of nonprofessional policing measures of which the reward system was a prominent part. ${ }^{423}$

Although the Macdaniel scandal broke close to Ryder, Ryder missed serious involvement in the cases both on assize and at the Old Bailey. ${ }^{424}$ Accordingly, the Ryder materials do not add much to the sources previously known, and I shall be brief in outlining the main features of the reward system and the scandal. This topic requires mention for its bearing on the larger context of the history of trial procedure. The Macdaniel scandal gave the courts reason to doubt the reliability of the evidence in another large and important class of cases of serious crime. Both the law of evidence and the adversary system, those epochal creations of the second half of the eighteenth century, were responses to the perception that the safeguards in the criminal trial had been inadequate to deal with the dangers posed by the prosecutions that were coming before the courts.

\section{A. The Reward System}

In 1692 Parliament enacted a statute "for encouraging the apprehending of Highway Men," statutes. It promised forty pounds to anyone "who shall apprehend and take One or more such Thieves or Robbers and prosecute him or them . . . until he or they be convicted." ${ }^{426}$ Over the next fifty years a series of similar acts came into force, offering rewards of

422 Rex v. Macdaniel, 19 ST. Tr. 745 (Old Bailey 1755); 1 E.H. EAST, A TrEatise on The Pleas of the Crown 333-34 (London 1803); M. Foster, Crown LaW, supra note 48, at 12132.

4232 L. RADzinowicz, supra note 49 , at 326-32, 337-39.

124 At Ryder's last Old Bailey sessions he heard a contested motion to delay the trial of Mary Jones, one of the gang. Ryder Notebook, supra note 19, at 59.

1284 W. \& M., ch. 8 (1692).

${ }^{428}$ Id. $\S 1$. 
varying amounts ${ }^{427}$ for convicting a variety of criminals: burglars and housebreakers; coiners; horse, sheep, and cattle thieves; shoplifters stealing above the clergyable amount; and persons returning prematurely from transportation. ${ }^{428}$ All were capital offenses.

The mechanism for payment was spelled out in the first act and is often evidenced in Ryder's assize diary. The act directed the trial judge to issue a certificate authorizing the sheriff to pay the reward, "and in case any Dispute shall happen to arise" in cases involving more than one claimant, the judge's certificate was to allocate the money "in such share and proportions as to the said Judge . . . shall seem just and reasonable."429 These documents came to be known as "blood money certificates," and some have survived in various archives; ${ }^{\mathbf{4 3 0}}$ the Treasury records of sheriffs' accounts also record the payment process. ${ }^{431}$

Ryder tried his first criminal calendar at Chelmsford assizes in the summer of 1754, and his diary shows the issuing of these certificates among other paperwork done at the end of the sessions. "I also signed several certificates for the distribution of the rewards . "432 In two cases involving multiple claimants he notes that he signed certificates prepared by the clerk of assize, the clerk "showing me in one instance an agreement under their hands, [and] in the other only saying [that] it was agreed between them." that so easily without [having] the parties . . . agree in writing or come to me and acknowledge it."434 Ryder was still thinking about this a few days later when he records the view of his fellow assize

${ }^{427}$ In lieu of or in addition to monetary rewards, some of the statutes offered so-called "Tyburn tickets," negotiable certificates of immunity from parish and ward offices. See the splendid account in $2 \mathrm{~L}$. RaDzinowicz, supra note 49, at 155-61.

428 See the convenient summary in P. Colquhoun, A Treatise on the Police of the METropolis 390-92 (7th ed. London 1806) (1st ed. London 1795).

4804 W. \& M., ch. 8, \& 1 (1692).

430 CLRO, Misc. MS 152.5 ("Sessions: Certificates for Reward for Apprehending Highwaymen and Housebreakers, 1732," 8 items); PRO, E 407/27-30 (blood money certificates, 1649-1800, several hundred loose documents). For the text of a model certificate see W. Stubbs \& G. Talmash, The Crown Circuit Companion 30-31 (London 1738).

431 E.g., PRO, T 53/45/353, 354, 455, for records of the rewards in some cases in our Old Bailey sample: Flemming, OBSP (Oct. 1754, \#505), at 330; Rolf, OBSP (Oct. 1754, \#504), at 326; Massey, OBSP (Oct. 1754, \#507), at 335; Watts \& Shilock, OBSP (Apr./May 1756, \#\#213-14), at 171. For assize cases for which Ryder signed the certificate, see PRO, T 53/ 45/354; see id. at 292 for the case of Richard Tickner, in which the reward was paid to Jeremiah Sippeth [sic], discussed supra note 110.

6s2 Ryder Assize Diary, supra note 21, at 7.

4ss Id.

434 Id. 
judge, Michael Foster, that "the distribution of all rewards under the statute[s] is by the court and not clerk of assizes." 35

Beyond the statutory reward system there were other important but irregular sources of reward money. The crown offered rewards intermittently by proclamation, often in particular cases of crown concern, but sometimes for categories of offense such as highway robbery and murder in the metropolis. Radzinowicz traced this practice well back into the seventeenth century, and he seems right in suspecting that the statutory scheme grew up in imitation of the earlier proclamation practice. ${ }^{438}$ In the eighteenth century the two systems overlapped, and at various times when proclamations were in effect it might be worth as much as $£ 140$ to prosecute a highway robber (£100 under proclamation, ${ }^{437} £ 40$ by statute $^{438}$ ). In addition to the rewards by proclamation, private parties were free to offer rewards, such as those we have seen in the advertisements in some of the Ryder-period cases. ${ }^{498}$ Toward the end of the century and into the nineteenth century the practice of offering rewards was taken up by governmental departments, local authorities, and the insurance-like private associations for the prosecution of felons. ${ }^{440}$

The potential for abuse that inhered in the reward system must have been apparent from the outset, even as Parliament was adding to the list of reward statutes. In 1732 one John Waller was convicted at the Old Bailey of a misdemeanor in attempting to prosecute someone falsely for highway robbery in order to collect the reward. There was evidence that he had succeeded in bringing such prosecutions in other counties. He was convicted and sentenced to be pilloried. When he appeared in the pillory, he was beaten to death by the brother of one of his victims, who was thereafter convicted of Waller's murder. ${ }^{411}$ Perhaps contemporaries

48s Id. at 15 . In a highway robbery case that was tried at Surrey assizes in 1755 , Ryder notes that he "distributed the rewards among the prosecutor and takers, though the Act gives it only to the takers, and [Ryder] included some that were not witness[es] but made out their case by affidavits." Id. at 28.

438 2 L. RADZiNowicz, supra note 49 , at $84-88$, esp. 88.

437 E.g., "An order was issued for apprehending Street Robbers in the City of London and Westminster, or within five Miles of the same, with a Reward of $\$ 100$ for all taken before 20th Dec. 1751," PRO, SP 37/15/491, at $497^{\mathrm{v}}$ ("Precedents . . . for apprehending Street Robbers ... .). (I owe this reference to Joanna Innes.)

4s8 4 W. \& M., ch. 8, \& 1 (1692).

439 See, e.g., supra text accompanying note 269 .

402 L. RADzinowicz, supra note 49, at 98-137.

441 John Waller, OBSP (May 1732, \#89), at 146; Edward Dalton et al., OBSP (Sept. 1732, \#\#86-88), at 219. There is a contemporary pamphlet account: THE LIFE \& ACTioNs OF John Waller, Who Made His Exit in the Pillory at the 7 Dials on 13 May 1732; Con- 
thought at first that such a case differed only in degree from a false prosecution conducted without the motive of a reward. For example, a pamphlet biography of a "Noted Street-Robber," Thomas

taining All the Villainies . . Swearing Robberies Against Innocent Prople, to Take Away Their Lives for the Sake of the Rewards . . (London 1732) (BL shelfmark 518.3.20), cited in G. Howson, supra note 25, at 324 .

In September 1733, one year after the Waller affair, the London grand jury complained against " 4 noted Solicitors for infamous Practices, in fomenting and carrying on Prosecutions against innocent Persons for the Sake of Rewards." 3 Gentriman's MaG. 493 (1733). A published memorial of the grand jury's complaint is less explicit than the report in the Gentleman's Magazine. It is printed on both sides of a page and bound in some collections of OBSP pamphlets, for example, that of the University of Chicago Law Library, immediately following the September 1733 OBSP pamphlet: "To the Right Honourable John Barber, Esquire, Lord-Mayor of the City of London; and Others His Majesty's Justices of the Peace at this General Sessions, Assembled, Sept. 15, 1733" [hereafter cited as 1733 Grand Jury Memorial]. It recites that because "many vexatious and litigious Prosecutions have appeared before us," the grand jurors have thought it fit "to enquire How, and in what Manner, such Prosecutions are fomented and stirred up, and by whom prosecuted and carried on." Id. at $1^{\mathrm{r}}$. The grand jurors' conclusion: "Clerks and Solicitors, in Confederacy with a Set of People, calling themselves Informing Constables, Newgate Solicitors, and Others ... excite and stir up ignorant and unwary People to enter into such Prosecutions . . .." Id. at $\mathrm{I}^{\mathrm{V}}$ (emphasis in original). In this instance the grand jury was probably complaining about abuses of the information qui tam statutes for regulatory offenses and misdemeanors rather than the felony reward statutes that were involved in the Waller and Macdaniel affairs. See generally 2 W. HAwKINS, supra note 157, ch. 26, at 264-80; on the history of the qui tam procedure in the Tudor-Stuart period see generally M.G. Davies, The EnrorceMENT OF ENGLISH APPRENTICESHIP 1563-1642 (1959).

In an anonymous pamphlet published a few years before the Waller case it was suggested that so-called Newgate solicitors encouraged victim/prosecutors to overcharge simple felonies in order to bring them within the ambit of the reward statutes. Directions ror Prosecuting Thieves Without the Help of Those False Guides, The Newgate SollicIтors 3-4 (London 1728) (Bodleian Law Library, Oxford, shelfmark L. Eng. B. 62 e. 93) [hereafter cited as Directions for Prosecuting Thieves].

[L]oose and vicious People ... are apt to strain the Circumstances in view of the Reward; and were not our Reverend Judges knowing and experienced in finding out the Truth, as well as just in the Administration of the Laws, by the Insinuations of the Solicitor, and the Covetousness of the Prosecutor, Truth would be perverted, and very frequently People hanged for a Burglary, when the Fact is only a single Felony, and for Street Robbery, when it was only a Quarrel between the Prosecutor and the Prisoner. Id. at 4. For further discussion of this pamphlet attack on Newgate solicitors, see infra note 511. (Newgate in this usage was a synonym for the Old Bailey; Newgate prison, which was nearby, held Old Bailey felony defendants for pretrial detention.)

The clerks of whom the London grand jury complained in the passage quoted earlier in this note are identified elsewhere in the grand jury's memorial as "Clerks or Servants to many of his Majesty's Justices of the Peace." 1733 Grand Jury Memorial, supra, at $1^{\mathrm{r}}$. The Memorial accuses them of exacting unauthorized fees: they "do, under Color, and in the Execution of their Office, exact and take from all Persons accused, and others bound to prosecute, several Sums of Money, under Pretense for Warrants, Commitments, Recognizances, Discharges, and other Matters incident to the Duty and Office of a Justice of Peace, contrary to the known Laws of this Realm, in Violation of Public Justice, and to the great Oppression of His Majesty's Subjects." Id. at $1^{\mathrm{r}}-1^{\mathrm{v}}$. Although nominally directed at the clerks, this criticism must have been aimed at their employers, the "trading justices" discussed supra text accompanying notes 219-23. 
Neaves, who was active in the 1720 s, recounts his ability to extort money from London low-lifers by threatening them with false prosecution if they did not pay. ${ }^{442}$

\section{B. The Macdaniel Scandal}

In January 1754 a young man named Joshua Kidden was prosecuted to his death for a bogus highway robbery alleged to have been committed on Mary Jones. She was in truth one of the gang. Other gang members arranged to entice Kidden to the scene and to frame him by planting a spurious "stolen" coin on him for her to identify before the examining magistrate. Macdaniel, the gang leader, "captured" the bewildered youth. Kidden's defense at his Old Bailey trial was ineffectual, and he was convicted and sentenced to death. ${ }^{443} \mathrm{He}$ sought executive clemency, and in his petition he alleges that his captor "McDonald [sic], [is] a Man of Bad repute, as your Petitioner is informed." Further, he says, after his trial some of his friends checked the address that Mary Jones gave at trial and found her unknown there. This, concludes Kidden, gives "great reason to believe that the said Prosecution was Calculated merely for the sake of the reward for convicting Felons."444 Kidden was not believed, and he was hanged on February 4, $1754 .{ }^{445}$

The gang attempted another false prosecution a few months later, again for a staged highway robbery, this time of two young men, Peter Kelly and John Ellis. Macdaniel set the scene in suburban Kent, so that the prosecution would occur at Home Circuit assizes rather than in the Old Bailey, where a fresh reappearance of the gang might have been noticed. The plot unraveled when by accident a high constable, Joseph Cox, became suspicious and conducted inquiries that finally detected the gang. Cox published a

\$12 Neaves Pamphlet, supra note'368, at 26. It was Neaves' practice to step to a Justice of the Peace, and having given some formal Account of a Robbery, sometime or other committed, he generally procured a Warrant, which he carried along with him, till he had an Opportunity of securing ... [his victims, unless they paid him off. Otherwise,] they were certainly charged in Custody, and sent to Prison on suspicion till he could (as he often pretended) find an Adversary to prosecute them.

Id. at 26.

4t3 OBSP (Jan. 1754, \#129), at 71.

44 PRO, SP 36/132/305.

4s OBSP (Feb./Mar. 1754), at 120 (report of the execution). Foster's laconic summary of the trial evidence, prepared in response to Kidden's petition for clemency, survives. PRO, SP 36/132/306. 


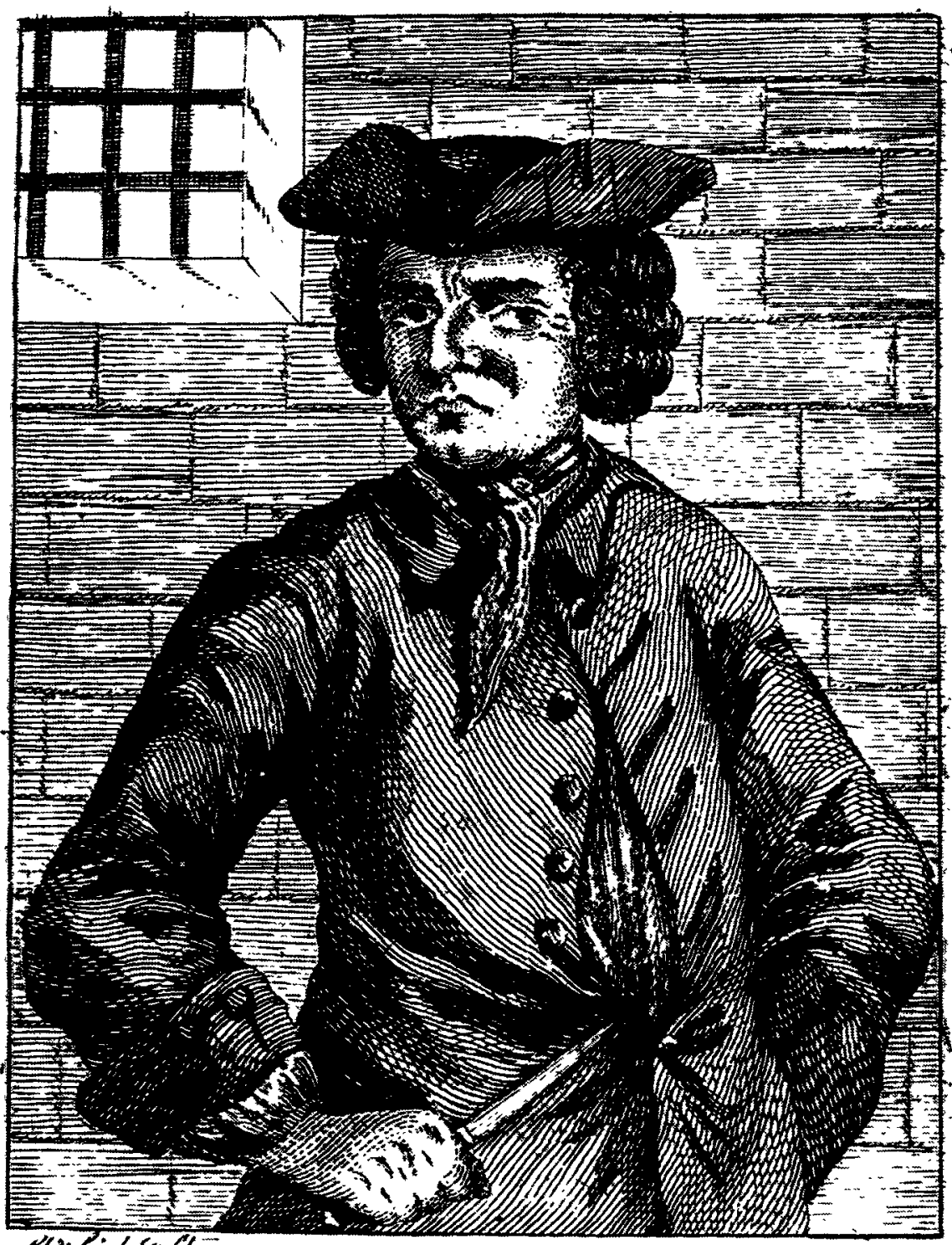
(j)" inghan."

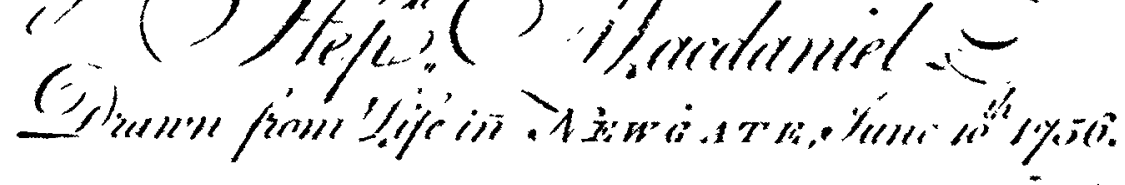


pamphlet about the affair a couple of years later, which is the principal source of information about these events. ${ }^{446}$ Cox followed up his investigation by getting one of the gang to turn crown witness. He then learned the truth about the Kidden case, and he established that the gang's activities extended back many years. ${ }^{447}$

Cox attended the Kent summer assizes, allowed the gang members to perjure themselves and to persuade the jury, which convicted the two young men. Cox then disclosed the plot and had Macdaniel and three other participants arrested. The trial judge who presided over this spectacle was Michael Foster, who happened to have presided at the trial of Joshua Kidden at the Old Bailey $^{448}$ and who was serving in the Home Circuit assize commission along with Dudley Ryder (who was handling the civil calendar that day). ${ }^{448}$

A series of prosecutions of the gang occurred over the next two years, including the unsuccessful one on the charge of murdering Kidden that produced the precedent previously mentioned. ${ }^{400}$ Four of the gang were convicted of conspiracy at the Old Bailey in February 1756 and sentenced to be pilloried and imprisoned. They were pilloried in pairs. Macdaniel and another were set out first, "and so great was the mob, that the peace-officers found it impossible to protect the prisoners from their fury." ${ }^{451}$ The first pair was only beaten. Three days later when the second pair was set out, one of the conspirators was stoned to death and the other maimed. 452

The Macdaniel scandal caused a sensation, and the contemporary press is full of it. ${ }^{453}$ The resulting series of prosecutions kept the incident in the public eye for years. ${ }^{454}$ John Fielding seems to have felt quite threatened by the events. He was concerned that the scandal would taint his Bow Street force, which also lived in

$418 \mathrm{~J}$. Cox, A Faithful Narrative of the Most Wicked and Inhuman Transactions of That Bloody-minded Gang of Thief-takers, Alitas Thief-makers, Macdanied ... (London 1756).

475 See the convenient tabulation that Radzinowicz extracted from Cox's pamphlet, $2 \mathrm{~L}$. RADZinowicz, supra note 49 , at 339 .

148 See supra note 445.

110 Ryder Assize Diary, supra note 21, at 11; PRO, Assi. 31/4/45, 47 (agenda book).

150 See supra note 422 and accompanying text.

411 Rex v. Macdaniel, 19 St. Tr. 745, 809 (Old Bailey 1755).

${ }^{402}$ Id. The illustration reproduced on page 113 shows why the pillory rendered a prisoner so defenseless to attack.

4s3 E.g., Gloucester Journal, Mar. 11, 1755, at 1, col. 3; id., Mar. 9, 1756, at 3, col. 3; id., Mar. 16, 1756, at 1, col. 3; id. at 3, col. 2; 25 Gentreman's Mag. 117-21 (1755).

4s4 2 L. Radzinowicz, supra note 49 , at 331. 


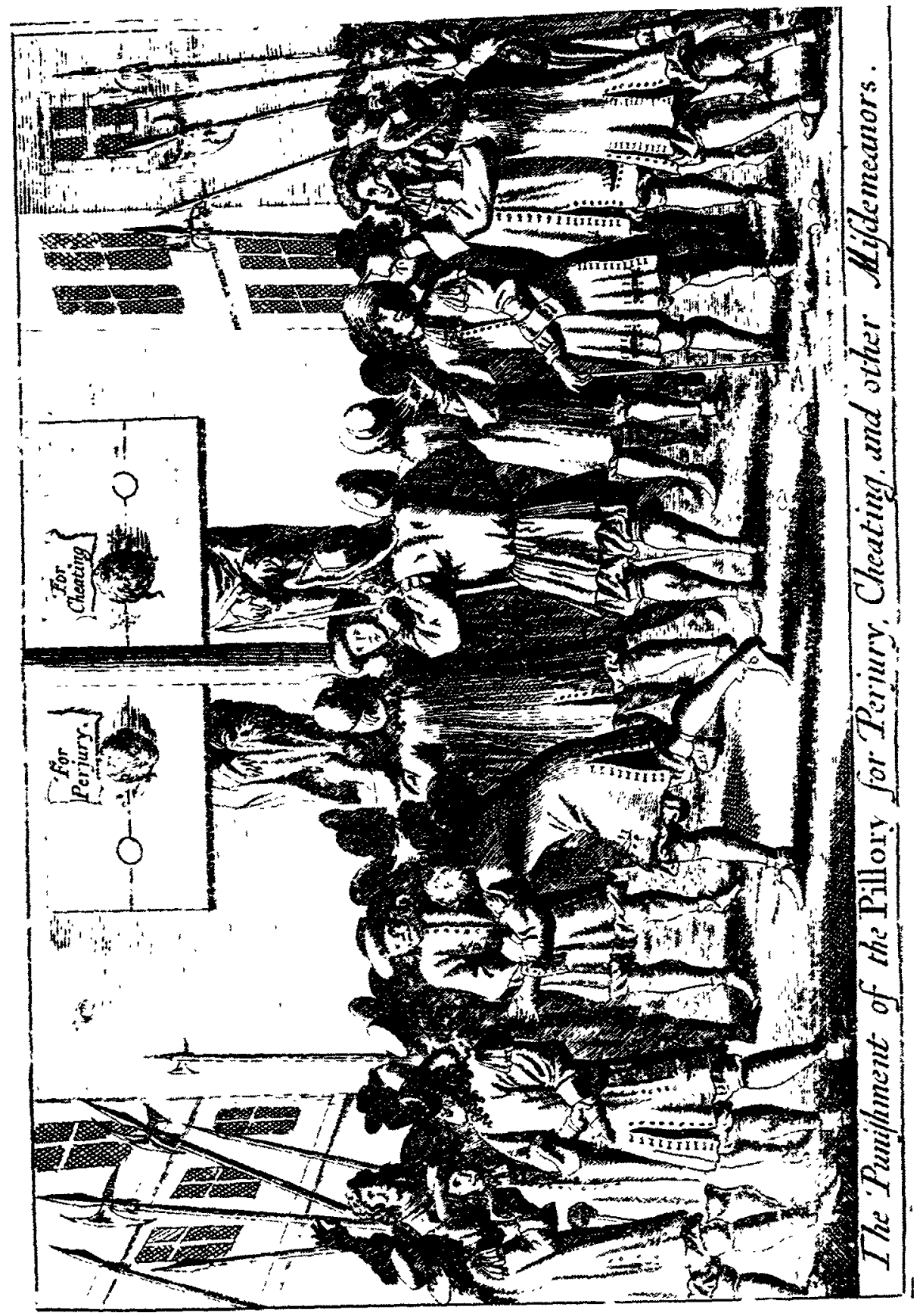


part from reward money. He published his Plan for Preventing Robberies within Twenty Miles of London in 1755 at the height of the scandal, and he began the tract defensively. "The perjuries of McDaniel [sic] and his crew having raised a strong prepossession against thieftakers in general, it seems proper at this time to publish a few facts, relating to the real and useful thieftakers . . . ."465 After describing some of the gangbusting achievements of his men, he argues that "it was the advantages received by these persons, as the just reward of their diligence, that tempted McDaniel [sic] and his hellish crew, to prostitute the useful employment of a thieftaker, to the procuring both public and private rewards, at the shameful and shocking price of innocent blood."456

However much John Fielding might succeed in distancing his men from Macdaniel's, his remarks were not likely to reassure anyone concerned that the reward system would not as easily provoke false witness in the future as in the immediate past. John ascribed to his late brother Henry an equally ineffectual suggestion, that the crown cease offering supplementary rewards by proclamation. According to John, Henry persuaded the Privy Council to take this step "in order to take away from these wretches their only temptation to perjury and murder." ${ }^{\prime 457}$ Of course, as the prosecution of Kidden shows, the statutory rewards alone had proved incentive enough for false witness. ${ }^{458}$

The Macdaniel scandal put the reward system under a cloud of doubt from which it never recovered. Nevertheless, it continued to function into the nineteenth century before the paid professional police force finally displaced it. Here again, as with the crown witness system, the people operating this ramshackle prosecutorial system felt compelled to rely upon an evidence-gathering technique of manifest untrustworthiness. That left it to the law courts to try to repair at the trial stage failures of institutional design in the pretrial process. The consequences would long outlive the institutions whose shortcomings were at fault. Professional police and prosecutors we would ultimately get, but we would never recover the criminal trial we were about to lose.

15s J. Fielding, Plan, supra note 234, at i.

4so Id. at 4.

487 Id. at 6.

158 PRO, T 60/20/84 (Treasury order book evidencing payment of $\$ 40$ to "Mary Jones, et al., for A \& C [apprehending and convicting] Joshua Kidden of Felony and Robbery"). 


\section{The Pace of Trial: Ryder on Assize}

Nothing distances the trial procedure of the Ryder years from its modern counterpart so much as its dispatch. The sheer volume of cases is stunning. Ryder saw more felony jury trials in a day or two than a modern English or American judge would expect to see in a year. At Ryder's first Old Bailey sessions in October 1754, for example, he presided over sixteen trials by two juries in three days. The other judges tried thirty-three other cases by the same two juries at the same sessions. ${ }^{459}$ Such caseloads had been common for many decades, both in the Old Bailey and at provincial assizes. ${ }^{460}$

In the former article treating Old Bailey sources of the period 1675-1735, I drew attention to caseload figures comparable to, indeed somewhat heavier than in the Ryder years, and I pointed to some of the factors that appeared to explain the rapidity of the procedure: the scheduling of trials close to the happening of the crimes, sometimes within a few days; prompt pretrial evidencegathering and sifting by the JPs; the virtual absence of lawyers for the prosecution or defense; the conversational informality of the trial; the constant resort to the accused as a testimonial resource; the recurrent use of jurors who were long experienced in jury work, men who needed comparatively little formal instruction on the essentials of criminal law and procedure; and the guidance that the jury received from the judge, who exercised an unrestricted power to comment on the merits. ${ }^{461}$

In this part of the present article, I want to take advantage of the Ryder sources to illustrate with some particularity this phenomenon of extreme rapidity in the handling of felony jury trials. The state of the sources is such that we can obtain a more detailed look at the processing of the criminal calendar by turning away from the Old Bailey to one of Ryder's assize sittings. Although we lack narrative accounts of the evidence presented at most of these trials, there is information in Ryder's diary and in the surviving public records that permits the rudiments to be reconstructed with time-of-day precision. We take as our example the summer 1754

45" Ryder dated each day of his sittings. E.g., "23 Oct. 1754. First day of the sessions at Old Bailey." Ryder Notebook, supra note 19, at 1 . He sat October 23-25. Id. at 1,8,14. The OBSP title page shows the court sitting on the two following business days, October 26 and 28. OBSP (Oct. 1754), at 305 . The last day was probably devoted to the pronouncing of sentence by the Recorder and to paperwork.

${ }^{460}$ For the Old Bailey see the discussion in Article I, supra note 1, at 274-78. Beattie reports 35 cases in two days at Surrey assizes in March 1750. Beattie, supra note 166, at 165.

461 Article I, supra note 1 , at 273-300. 


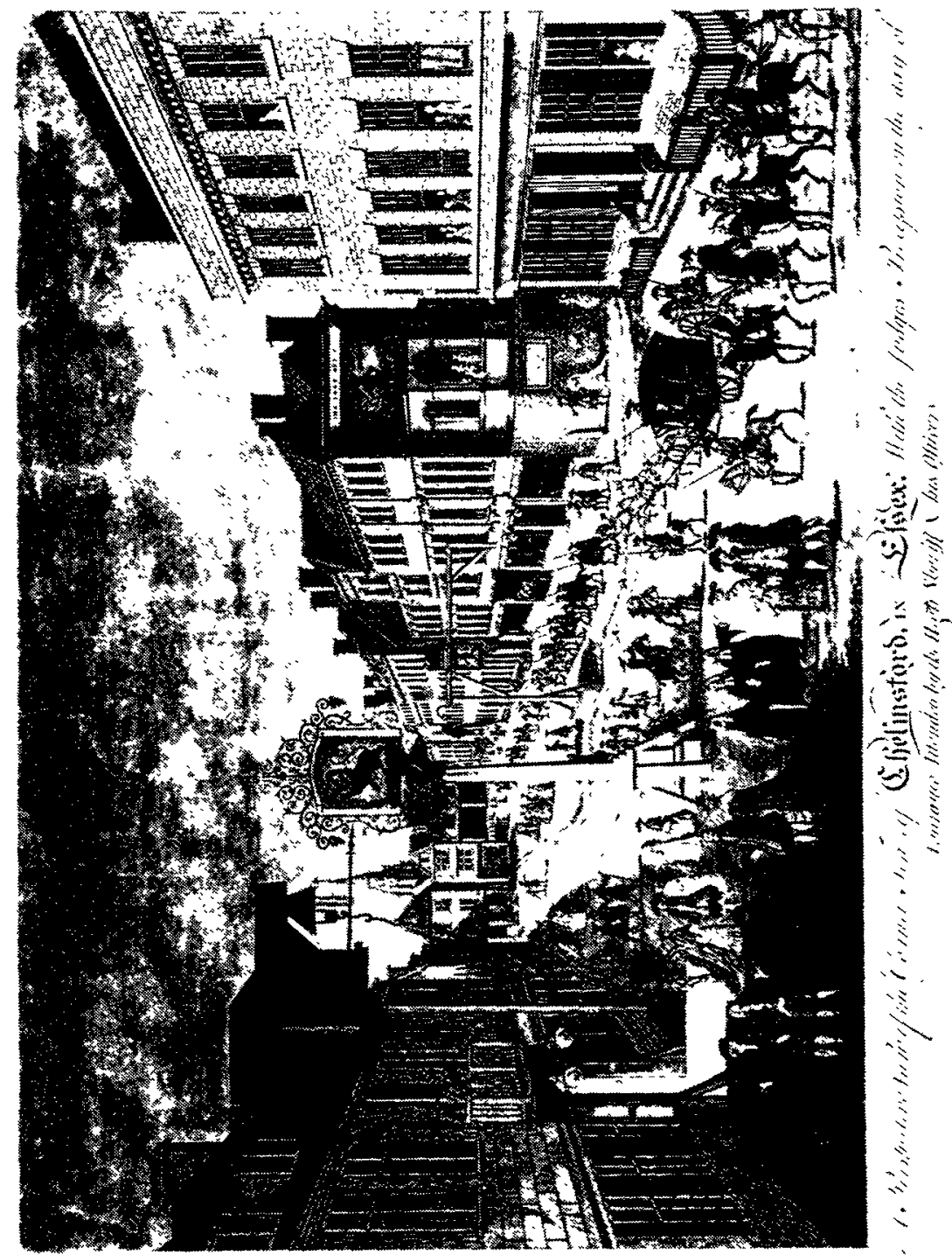


assizes for Essex, held in Chelmsford, the first occasion on which Ryder presided over the "crown" or criminal side.

Ryder and his fellow judge, Foster (who took the civil calendar in Essex for that assize), arrived in Chelmsford on Wednesday, August seventh. They entered the town in ceremonial procession, ${ }^{\mathbf{1 6 2}}$ escorted by the sheriff and undersheriffs and "opened the court only that evening." journed until eleven o'clock the next morning. ${ }^{464}$ Thursday morning after attending church and hearing the assize sermon, Ryder reconvened the crown side of the court and delivered the charge to the grand jury. ${ }^{485}$ Ryder adjourned the court until four o'clock in the afternoon, which allowed the grand jury to consider and return its first indictments for trial that afternoon. (By contrast, for Old Bailey sessions, the Middlesex grand jury met earlier and at some distance in Hicks Hall, while the London grand jury sat at the Old Bailey. $\left.{ }^{48}\right)$ The judges entertained thirty-six persons for dinner, in-

162 The picture reproduced in this article at page 116 shows the Chelmsford assize procession in 1762, a few years after Ryder's tour. The artist, David Ogborne, is noted in 14 DNB, supra note 16, at 904 (entry by C. Fell-Smith). (John Baker directed my attention to this illustration.)

16s Ryder Assize Diary, supra note 21, at 3.

16 PRO, Assi. 31/4/41 (agenda book).

14 Ryder Assize Diary, supra note 21, at 4. Five of Ryder's charges have been transcribed from shorthand into typescript. Sandon Hall, Ryder Shorthand MS, Harrowby MS vol. 431, docs. 19(a)-19(e). For a compilation of published eighteenth-century grand jury charges, see EighteEnth-CENTURy Bibliography, supra note 122, at 403-06.

168 John Fielding left this account of the indictment process in a work published in 1761:

Bills of Indictment for Felony in the County of Middlesex, are preferred before the Grand Jury at Hicks Hall in St. John's Street, where there are two Clerks, viz. Mr. "Higgs and Mr. Mason, who are appointed to draw the same. Mr. Higgs draws the Indictments against such Felons whose Name or Names begin with any Letter in the Alphabet from $A$ to $M$ and Mr. Mason draws those against such whose Names begin with any Letter in the remaining Part of the Alphabet; and Prosecutors for Felony should endeavor, if possible, to be at Hicks Hall on the Tuesday Morning in the Sessions Week, and take with them their Witnesses; and it will always save their Time, if they carry with them in Writing, the Name or Names of the Prisoner or Prisoners, with the Names of the Witnesses, and an Account of the Things stolen, and the Time when; which they must give to the Clerk of the Indictments, agreeable to the above Rule of the Alphabet, and if the Bill be there found a true Bill, they must immediately attend the Old Bailey, where the Offender will be tried; and if the Offense is committed in the City of London, the Prosecutor must prefer his Bill of Indictment at the Old Bailey, and apply to Mr. Ford.

J. Fielding, supra note 282, at 222 (emphasis in original). According to a pamphlet published 40 years earlier, indictments arising from offenses committed in Middlesex were drafted at Hicks Hall, but those for offenses committed in the city proper were at that time being prepared at the Guildhall. Directions for Prosecuting ThIeves, supra note 441, at 5. Victim/prosecutors were advised that

the Person appointed to draw up the Bills [is to be paid] two Shillings . . ; and when 
cluding such of ]the magistracy as were not busy sitting on the grand jury. ${ }^{467}$

When the court reconvened for the afternoon, a petty jury was sworn. ${ }^{468}$ Elsewhere in the diary Ryder remarked that "[s]everal prisoners are commonly arraigned together and the same jury charged with them," 469 and this was probably the practice that afternoon at Chelmsford, where the jury heard three trials. Roger Leech was convicted of a horsetheft and William Bearman of a sheeptheft, each a capital offense. (At the end of the assizes Ryder sentenced them to death but reprieved them for executive clemency; they were transported. ${ }^{470}$ ) Daniel Goodwin, tried for burglary, was convicted of simple grand larceny and later transported. ${ }^{471}$

Friday the ninth was the main trial day. Court resumed at seven o'clock in the morning with the same trial jury. ${ }^{472}$ The jurors convicted two more felons, Thomas Dawes for grand larceny (stealing goods valued at thirty pounds) and Frances Cheek for the murder of her six-month-old child. Ryder summarized the facts and proceedings in Cheek's case in several paragraphs, one of the two most detailed reports in the diary, ${ }^{473}$ for the case obviously affected him. The crime had been committed unwitnessed; a neighbor found the woman kneeling over her dying child with the murder weapon, a chicken hook, at her side. There was conflicting evidence about whether she was sane.

the Bill is drawn up, you swear to it, for which you are to pay Four Pence; and then go with your most material Witnesses to the Grand Jury, who likewise sit in Guildhall and Hicks Hall; and then you relate upon Oath the Circumstances, and what Reason you have to charge the Prisoner. If your Evidence amounts to a good and clear Proof, the Bill is found, and will be transmitted to the Old Bailey . . . .

Id. at 6 (emphasis in original). The author of the pamphlet argues that victim/prosecutors will get better indictment drafting without the intermediation of solicitors, since "the Gentleman who draws up the Indictment believing a Solicitor able to express it in proper Terms, and [believing] that he takes Care to do so, seldom examines strictly how the nature of the Case is." Id. at 9. Thus, "if you observe the Instructions herein given, and do your Business without a Solicitor, the whole Prosecution of a Thief will cost you no more than two Shillings and four Pence." Id. at 11.

${ }^{487}$ Ryder Assize Diary, supra note 21, at 4; see supra note 375.

168 PRO, Assi. 31/4/42.

169 Ryder Assize Diary, supra note 21, at 15. Accord W. StubBs \& G. TAlmash, supra note 430 , at 22 ("so many are arraigned, as will serve for a Petty Jury to pass upon at once").

470 PRO, Assi. 31/4/42; Ryder Assize Diary, supra note 21, at 5; PRO, T 90/149/2 (sheriff's craving recording detention of both convicts until transported).

${ }^{471}$ PRO, Assi. 31/4/42.

472 Id.

473 The other is Sir John Balfour's case, discussed infra note 504. 
I told the jury they must consider whether she did the fact, and if so whether she was out of her senses when she did the fact, immaterial whether she was so afterwards when she reflected what she had done .... The jury first said they were satisfied she killed the child but doubted her sanity. I explained again to them the nature of the case rather against the prisoner. They went out and in about hour and half brought her in guilty. I then told them I was very well satisfied. ${ }^{474}$

This remarkable technique of jury control, to which I drew attention in the previous article, ${ }^{475}$ whereby the judge might provisionally refuse to enter a verdict that displeased him, reinstruct the jury, and require it to redeliberate, gives a revealing insight into the extent of the influence that contemporaries expected the mid-eighteenth-century judge to exercise over the adjudicative work of the jury. Ryder at once sentenced Cheek to be hanged and anatomized, pursuant to the Murder Act of $1752 .{ }^{476}$ He writes that he made a speech on this occasion "in which I was so affected that the tears were gushing out several times against my will, it was discerned by all the company-which was large-and a lady gave me her handkerchief dipped in lavender water to help me."477

The records show that a new jury was impaneled for the remainder of the cases, ${ }^{478}$ almost certainly in order that Ryder could continue to work his way through his trial calendar while the first jury undertook its "protracted" hour-and-a-half deliberation over Francis Cheek. (At the Old Bailey, where separate London and Middlesex juries were impaneled at the outset, this alternation of jury sittings was also practiced-one hearing fresh cases while the other deliberated. ${ }^{479}$ ) Four more cases were tried that morning to the new Essex jury. It convicted George Carter of a sheeptheft for which he was later sentenced to death and hanged. ${ }^{480}$ It convicted in two further larceny cases, downcharging one to petty larceny for which the convict was whipped. The jury acquitted in the fourth

674 Ryder Assize Diary, supra note 21, at 4.

"7s Article I, supra note 1, at 291-95.

476 Ryder Assize Diary, supra note 21, at 5. Regarding sentencing for murder, see supra text accompanying notes 181-84.

${ }^{677}$ Ryder Assize Diary, supra note 21, at 5. Douglas Hay quoted this passage in Hay, supra note 21, at 29. Sheriff's craving for her execution: PRO, T 90/149/2r.

178 PRO, Assi. 31/4/43.

679 See Article I, supra note 1, at 274-75.

4so PRO, Assi. 31/4/43; sheriff's craving for his execution: PRO, T 90/149/2v 
case. ${ }^{481}$

The court adjourned for midday before returning to complete its calendar. The Reverend Martin Madan, writing a generation later in 1785, suggests that this break did not always promote the ends of justice:

Another cause of much evil is the trying prisoners after dinner; when, from the morning's adjournment, all parties have retired to a hearty meal; which, at assize-time, is commonly attended, among the middling and lower ranks of people, at least, with a good deal of drink. The symptoms of this vulgar species of festivity are usually too apparent, when the court assembles in the afternoon-the noise, crowd, and confusion, which these occasion, seldom cost the Judge less than about an hour, before the court can be brought into any kind of order; and when this is done, drunkenness is too frequently apparent, where it ought of all things to be avoided, I mean, in jurymen and witnesses. The heat of the court, joined to the fumes of the liquor, has laid many an honest juryman into a calm and profound sleep, and sometimes it has been no small trouble for his fellows to jog him into the verdict-even where a wretch's life has depended on the event!-This I myself have seen-as also witnesses, by no means in a proper situation to give their evidence. ${ }^{\mathbf{4 8 2}}$

Such festivities are not evidenced in the Ryder materials. When Ryder reconvened the Friday afternoon session, he continued to employ the second jury for the remainder of the caseload. The jury convicted Thomas Stebbing of a burglary; he was later sentenced to death but reprieved and ultimately transported.483 In the last felony jury trial, the eleventh in less than a day and a half of trial time, Mary Goodspin was charged with theft from a dwelling house above the capital amount; the jury downvalued and she was transported. ${ }^{484}$ The day concluded with a misdemeanor prosecution: John Young pleaded guilty to wearing the pretender's colors on the streets of Colchester "in derision of his present majesty." ${ }^{485} \mathrm{He}$ was fined and jailed for two months. ${ }^{486}$

81 PRO, Assi. 31/4/43.

182 M. MADAN, supra note 49 , at $148-50$ (emphasis in original).

(8s PRO, Assi. 31/4/44; Ryder Assize Diary, supra note 21, at 5; PRO, T 90/149/2 $90 / 150 / 1^{\mathrm{V}}$.

484 PRO, Assi. 31/4/44.

485 Ryder Assize Diary, supra note 21, at 6.

${ }^{486}$ PRO, Assi. 31/4/44. 
Guilty pleas such as that in the Essex misdemeanor case occurred rarely. There was none among the eleven felony trials. ${ }^{487}$ In our Old Bailey sample of 171 cases we find only a couple of guilty pleas, ${ }^{488}$ even though numerous accused admitted their guilt at trial after pleading not guilty. ${ }^{489}$ In the previous article I assembled evidence showing that the bench had a positive preference for pleas of not guilty and that it was standard practice to try to dissuade an accused from pleading guilty. ${ }^{400}$ Because trial was so rapid, there was no pressure to divert cases into nontrial modes of procedure of the sort familiar in our own day, such as plea bargaining and (in the United States) jury-waiver or bench trial. ${ }^{41}$ Every prosecution for a serious crime went to full jury trial, including the many open-and-shut cases that in modern times would almost all be diverted from jury trial. The aggregate caseload figures blend these easy cases, some of which must have been tried in a few minutes, together with the seriously contested cases that took more trial time. On the other hand, because (as we have already explained ${ }^{482}$ ) these trials were serving as sentencing proceedings designed to help the jury decide whether to downcharge or downvalue, evidence of the circumstances of the offense and the offender was often adduced even in cases in which guilt was not in doubt. In the 1750 s a very exceptional felony trial might take a day to try, ${ }^{498}$ but that was an outer limit. ${ }^{494}$

107 It was ancient practice for the clerks to record in various official records that the accused put himself upon jury trial. The 11 felony cases tried before Ryder at this sessions and recorded in the Essex assizes agenda book, PRO, Assi. 31/4/42-44, all bear that notation.

413 John Venters, OBSP (Apr./May 1756, \#198), at 167; William Jones, OBSP (Apr./ May 1756, \#217), at 173.

sse E.g., Mary Clinch, OBSP (Apr. 1755, \#197), at 183 ("The prisoner owned the fact.").

400 Article I, supra note 1, at 278-79. Only by pleading not guilty could the accused have the opportunity to present evidence bearing on sanction. Beattie quotes a Surrey assize judge in 1751 explaining why, in one of the rare cases in which the accused persisted in pleading guilty to a capital offense, the judge let him hang: the guilty plea had "shut [the judge] out from all evidence and circumstances favorable and disfavorable which might have appeared." Beattie, supra note 166, at 173.

${ }^{101}$ See generally Towne, supra note 117; Langbein, Understanding the Short History of Plea Bargaining, 13 LAw \& Soc'y Rev. 261 (1979); Alschuler, Plea Bargaining and Its History, 79 CoLum. L. REv. 1 (1979).

192 See supra text preceding note 161.

43s In the case of Rex v. Mary Blandy, 18 ST. TR. 1117 (Oxford assizes 1752), a contemporary account remarked that the trial "lasted twelve hours." 22 Gentzeman's Mag. 108, 109 (1752).

434 It was not until 1794 that a trial for serious crime "ever lasted more than one day, and [in that case] the Court seriously considered whether it had any power to adjourn." Mackinnon, The Law and the Lawyers, in 2 Johnson's ENGLAND 307 (A.S. Turberville ed. 1933). 
Assizes were scheduled well in advance; the number of trial days per assize town was predetermined. We are tempted to wonder if this may have contributed to the frenzy of these sittings-there was no flexibility to linger if the trials ran long. Usually, however, the criminal calendar went faster than the civil. In our example, Ryder had Saturday in reserve, which he used for the sentencing ceremony and for paperwork ${ }^{495}$ (including, perhaps, the making of the diary that has helped us to follow these events). Furthermore, the Old Bailey was at least as rapid, and there the

495 Including reward certificates, noticed supra text accompanying note 432 , and the award of prosecutors' costs.

The scheme for subsidizing prosecutors' and witnesses' costs was quite recent in Ryder's day, having been enacted by 25 Geo. 2, ch. 36, § 11 (1752), and 27 Geo. 2, ch. $3, \S 3$ (1754). Henry Fielding had urged such legislation. See H. FirLding, Enquiry, supra note 186, at 109-10. Amory, who has advanced persuasive grounds for doubting Fielding's influence upon some of the penal-law measures credited to him, see supra note 178, concedes that "[t]he provision allowing prosecutors their expenses in hardship cases [and another unrelated measure] ... are almost precisely the solutions proposed for these problems by the Enquiry." Amory, supra note 178, at 188 (footnote omitted).

Following the 1754 Chelmsford assizes, Ryder made some observations in his diary concerning practice under the 1752 act:

Note: clerk of assizes told me that the judges having construed the Act of 25 G.2 that provides for the payment of the charges to prosecutors to mean only poor persons, and therefore, there being now two or three prosecutors that desired their charges, I ordered one of them claiming [i.e., one of the persons who applied for costs] not to have them because he appeared to be an innkeeper of external appearance. [Ryder repeated this observation in different and somewhat clearer words a few paragraphs later: "Clerk of assizes told me the judges construed the act of $25 \mathrm{G} .2$ that directs the county treasurer to pay the prosecutors of indictment for felony their charges and trouble to mean only where poor persons are prosecutors, and accordingly I refused to sign one for a prosecutor that kept a public house of considerable figure, and did it for others."] But I settled the costs of three others who appeared to be poor, but without any affidavit of their poverty and without affidavit of their charges, and . . . as the Act provides also for lost time I allowed charges for loss of time, but they altogether made but small sums.

Ryder Assize Diary, supra note 21, at 7. At Sussex assizes the following week Ryder again recorded in the diary what he had done and what he had learned about practice under the statute:

I settled four bills for costs for prosecutors on statute of 25 G.2. [Such bills] [s]hould include none but costs to account for the assizes and not the costs of pursuing the prisoner and taking him beforehand, [n]or the costs of the constable for that purpose which is provided for per 27 G.2 to be paid by order of [quarter] sessions or justices. Also that in truth the costs ought to be proved by affidavit, but they being ... . allowed ... also for time and trouble, the practice has been to lump them all in 5 shillings a day for each person, and to do this at our own lodgings, not in open court nor on oath as the Acts or one of them requires. Also the clerk of assizes says the judges have thought it not proper to give any costs where [prosecutors] have a $\$ 40$ reward or other benefit. And in the present case, the prosecutor having right to a certificate assignable to discharge from parochial [duties, that is, a so-called Tyburn ticket, mentioned supra note 427], I did not give costs.

Id. at 13. Another such notation appears in id. at 16, recorded following Surrey assizes. 
Recorder could stay on duty even if the judges from Westminster were engaged elsewhere. Because such crowded calendars were standard at assizes, we ought to assume that they were deliberate. They could have been avoided by increasing the duration of the assizes. Accordingly, the inference seems fair that contemporaries thought that these trial times were appropriate to the need.

\section{Trial: First Stirrings of Adversary Procedure}

Over the course of the eighteenth century our criminal procedure underwent its epochal transformation from a predominantly nonadversarial system to an identifiably adversarial one. In the early decades of the century, an English criminal trial still resembled in the main the unstructured "altercation"498 amongst accusers and accused that Sir Thomas Smith described for Elizabethan times. Since the accused had been indicted, he was likely to be guilty. The purpose of trial was to allow him to answer-in the sense of explaining-the charges against him. We see this conception in the great state trials of the sixteenth century, where the accused was invited to answer each piece of prosecution evidence as it was adduced ("how say you Throckmorton, can you deny it? . . . . But how say you to this . . ?"487). As late as 1721, when Hawkins undertook in his Pleas of the Crown to justify the rule denying the accused the assistance of counsel, he invoked this ancient conception of the function of the trial.

[E]very one of Common Understanding may as properly speak to a Matter of Fact, as if he were the best Lawyer; . . . it requires no manner of Skill to make a plain and honest Defense . . . . Whereas on the other Side, the very Speech, Gesture and Countenance, and Manner of Defense of those who are Guilty, when they speak for themselves, may often help to disclose the Truth, which probably would not so well be discovered from the artificial Defense of others speaking for them. ${ }^{488}$

196 T. SMITH, De REPUblics, supra note 316 , at 100.

197 Regina v. Throckmorton, 1 ST. Tr. 869, 873-74 (1554).

400 2 W. HAwkINs, supra note 157 , ch. 39 , $\$ 2$, at 400 .

In 1728, seven years after Hawkins published his remarks on the virtues of having criminal defendants speak at trial without the help of lawyers, an anonymous pamphlet advanced a similar view regarding prosecution evidence. The victim need not engage a solicitor, says the writer, "and nothing pleases the Judges, more, than to hear Truth told with the utmost Simplicity and Plainness." Direcrions for Prosecuting ThIEves, supra note 441, at 5. "[W] hat is easier than to speak Truth, and what you know and saw . . ."? Id. at 6. See also id. at 12-13. 
Hawkins' message is that it is desirable for the accused to speak, either to clear himself or to hang himself.

I observed in the former article that until the 1730s lawyers seldom appeared for the prosecution and never for the defense. Although the accused was disqualified from testifying on oath, he was allowed to speak unsworn and thus to have a testimonial role. Since he was denied counsel, he also had to conduct his own defense, and these roles were impossible to disentangle. The prosecuting victim, the accused, and the witnesses would be "examined" and "cross-examined" by the presiding judge, as well as by one another, in a relatively conversational way. ${ }^{498}$ There was as yet no articulation of prosecution and defense "cases," hence the burdens of production and proof had yet to be developed. The exclusionary apparatus of the later law of evidence was all but nonexistent, apart from the relatively inconsequential rules about privilege and competency. ${ }^{500}$

The trial procedure that can be reconstructed from the Ryder sources seems much closer to the casual and lawyer-free world of Sir Thomas Smith's altercation than to the truly adversarial procedure we have come to know. But we think that we can detect in the Ryder years some shifts that, in the full light of hindsight, appear to presage the future.

There is little indication in the Ryder-period sources that lawyers for prosecution and defense were appearing materially more frequently in the mid-1750s than in the mid-1730s (the period in which we were first able to detect a steady trickle of prosecution counsel and in which the relaxation of the rule forbidding defense counsel occurred). ${ }^{\text {sol }}$ For our 171-case Old Bailey sample we are certain that prosecution counsel appeared in six cases; defense counsel opposed prosecution counsel in two of these cases and appeared in six others for which prosecution counsel are not evidenced. Thus, lawyers' appearances can be documented in a total of twelve cases. ${ }^{\mathrm{s} 2}$ In a few others the OBSP report unattributed

409 Article $I$, supra note 1, at 282-84. For an instance of the court cross-examining an accused, see the case of John Emerton, OBSP (Jan. 1733, \# 32), at 41-44. This practice ceased by the Ryder period.

${ }^{300}$ Article I, supra note 1, at 300-06, 314-16.

${ }^{501}$ Id. at $307-14$.

${ }^{802}$ I have previously noticed seven cases in which the Ryder notebook establishes the presence of counsel. See supra note 80 . Those in which the OBSP narratives disclose counsel include two in which both prosecution and defense were represented: the murder trial of Mary Smith, OBSP (Oct. 1755, \#389), at 340; Ryder Notebook, supra note 19, at 41; and the trial of Charles Wiesenthall for suborning perjury, OBSP (Apr./May 1756, \#228), at 179.

In addition, the OBSP show prosecution counsel in one case, Elizabeth Upton, theft of 
cross-examinations so vigorous that we suspect that they were the work of counsel. ${ }^{303}$ Ryder's assize diary allows us to identify defense counsel in only one case in his two years of sittings on the Home Circuit. ${ }^{504}$

household staples and money, OBSP (Oct. 1754, \#506), at 331. The pamphlets report defense counsel in two further cases: Alexander Murdock, shoptheft of cloth and money, OBSP (Oct. 1755, \#377), at 333; and Abraham Davis et al., for stealing of rum from a warehouse, OBSP (Oct. 1755, \#\#390-92), at 349; Ryder Notebook, supra note 19, at 36 (a case cited supra note 80 as one in which the Ryder notebook alone discloses prosecution counsel).

${ }^{\text {sos }}$ See, e.g., Elizabeth Upton, OBSP (Oct. 1754, \#506), at 331, cited supra note 502, for explicit mention of prosecution counsel; the report contains a vigorous "Cross Examination" of the prosecutor, id. at 332, and of the main prosecution witness, id. at 333. For other instances of cross-examination, see Philip Abrahams, OBSP (Apr. 1755, \#190), at 177; Girolamo Ferri, OBSP (Apr./May 1756, \#175), at 160; Thomas Commin, OBSP (Apr./May 1756, \#183), at 163-69.

sor The case of Sir John Balfour, tried for murder at Essex summer assizes, 1755, arose from drunken insults traded in a pub, which led to a brawl that ended with Balfour stabbing his protagonist to death. Ryder Assize Diary, supra note 21, at 21. Balfour's defense was that provocation negatived malice, hence that the facts amounted only to manslaughter (for which the sanction was simple release with a branding, see supra notes 146, 167 and accompanying text). Doubtless through counsel's design, Balfour succeeded in having the case put to the jury for the return of a special verdict. The sole mention of counsel comes in Ryder's discussion of the paperwork for the special verdict:

The minutes as above almost verbatim [i.e., Ryder's summary of the facts stated in the special verdict] were signed by counsel for the plaintiff [sic; defendant] Mr. Harvey and Cox and by clerk of assizes, there being no counsel for the King, but not by the jury, that being thought not necessary. It was agreed I should lay this minute before the 12 judges for their opinion as in the late case of [words obscure], the consequence of which will be that when their opinion is taken it will be sent to next judge of assizes at Chelmsford, who will give judgment according to that opinion.

Ryder Assize Diary, supra note 21, at 22. Perhaps because Ryder anticipated being asked to report on the case for the other judges, he reflected on the issues for several paragraphs following the paragraph just quoted. He makes a pair of references to $1 \mathrm{M}$. HaLE, supra note 241, at 456, 457. Ryder Assize Diary, supra note 21, at 22. He concludes on the merits: "Note: on the whole I now think it is murder." Id. at 23. (Regarding the Twelve Judges procedure, see supra text accompanying note 402 .)

The case ultimately was resolved by pardon rather than by opinion of the Twelve Judges. Two months after the assize proceedings, Ryder received a letter from one of the secretaries of state asking him whether Balfour should be pardoned. Ryder's cautious reply survives. PRO, SP 36/132/84 (Oct. 9, 1755). Ryder enclosed a copy of the special verdict, PRO, SP $36 / 132 / 85$, and noted that for the most part the factors bearing on clemency were those that might justify treating the case as manslaughter rather than murder. Noting that the Twelve Judges were about to consider "in Point of Law what the Nature of [Balfour's] Guilt is," Ryder wrote that "I am not at Liberty to give my Particular Thoughts while that Question is yet depending before the whole Bench of Justices." PRO, SP 36/132/84".

Within a fortnight the monarch had decided to pardon Balfour; the date of October 23 appears in a letter from the Attorney General, William Murray, later Lord Mansfield, advising the crown on the mechanics of implementing a pardon for an accused whose case was the subject of a special verdict that had not gone to conviction. PRO, SP $36 / 132 / 137^{\mathrm{V}}$ (Nov. 12, 1755). According to the Essex sheriff's craving, it still took a while to implement the decision. The sheriff claimed recompense for "guarding, keeping, and maintaining" Balfour 
We cannot exclude the possibility that our sources are deceiving us, and that there was much more lawyerly activity than we can now trace. In half the twelve cases in our sample, the OBSP omitted to disclose the presence of counsel; we know them only from the Ryder notebook. ${ }^{508}$ That source is, however, sufficiently copious that we think it unlikely that any large lawyerly contributions went unrecorded. More generally, because so many of the accused were paupers caught red-handed, it seems improbable that they had the means or felt much need to employ counsel. We must be missing mention of counsel in some OBSP cases for which we have no cross-check in the Ryder notes, but we do not think that the lawyerly presence was massively larger than the OBSP disclose.

Although prosecution counsel had been allowed for centuries, his role in these ordinary felony cases appears less developed than that of defense counsel. He appeared less and he mattered less. In two cases he had the look of a stand-in for owners of stolen property who had not been witnesses to the thefts and who bought their way out of attendance at the trial by sending counsel. ${ }^{506}$ In the other four cases, the victims (in one of them, a homicide case, the kin) seem to have felt especially aggrieved and hired counsel to make certain that things were done right. But the tradition was strong that counsel was not necessary; the trial judge was the examiner-in-chief for the prosecution, and he cross-examined defense witnesses. ${ }^{507}$ The expectation was that the victim and the other

until January 24, 1756. PRO, T 90/149/2v.

sos See supra note 80 and accompanying text.

sos William Cottom, OBSP (Oct. 1754, \#477), at 310; Ryder Notebook, supra note 19, at 6, 7 ("The counsel for the prosecutor the Major said that the Major desired [that the culprit] might be recommended to mercy"); Abraham Davis et al., OBSP (Oct. 1755, \#39092), at 349; Ryder Notebook, supra note 19, at 36.

${ }^{802}$ Henry Fielding makes a remark in his Enquiry of 1751 that shows that prosecution counsel was still not expected, which is why Fielding expected the Recorder of London to probe the testimony of defense witnesses:

The usual Defense of a Thief, especially at the Old Bailey, is an Alibi: To prove this by Perjury is a common Act of Newgate Friendship and there seldom is any Diffculty in procuring such Witnesses. I remember a Felon within this Twelvemonth to have been proved to be in Ireland at the Time when the Robbery was sworn to have been done in London, and acquitted; but he was scarce gone from the Bar, when the Witness was himself arrested for a Robbery committed in London at that very Time when he swore both he and his Friend were in Dublin: For which Robbery, I think, he was tried and executed. This kind of Defense was in a great Measure defeated by the late Baron Thomson, when he was Recorder of London, whose Memory deserves great Honor for the Services he did the Public in that Post. These Witnesses should always be examined with the utmost Care and Strictness, by which Means the Truth (especially if there be more Witnesses than one to the pretended Fact) will generally be 
witnesses bound over to trial by the JP could present their evidence without the intermediation of counsel. In the cases where prosecuting counsel did appear, we would be hard put to point to any facet in which he affected the outcome.

In his assize diary, Ryder mentions a conversation in which Foster tells Ryder that "the clerk of assizes takes on him[self] sometimes [to act] as prosecutor for the King to examine witnesses, but [Foster] has sometimes stopped him. Though note, it don't seem to me improper for him to do it." commonly this occurred or whether it was connected to the seventeenth-century practice previously discussed that the JPs' pretrial examinations were read to the court by the clerk "if [they] be Evidence for the King."

Decades after the Ryder years it was still thought unnecessary to have prosecuting counsel unless special circumstances warranted. We may contrast on this point a pair of entries-the only material ones-contained in the manuscript minute book of the London Society for Prosecuting Felons. In one case arising in October $1795, \mathrm{Mr}$. Dinsdale, a member of the society entitled to its support, "reported a Burglary in his House" committed by two men, one of whom was caught in the act and bound over for trial by the Lord Mayor. The society "Resolved, that this Prosecution be carried on by the Society and that the case is too clear to need the assistance of Attorney or Counsel.""510 Accordingly, the society's help was limited to drafting and submitting the indictment. Another case a few months earlier involved a bullock lost by $\mathbf{M r}$. Harper and recovered from two drivers after being advertised. The minute book records that since the culprits "had employed Counsel," Mr. Harper "submitted it to the Society of employing one of the Society's Solicitors to prevent the Offenders from escaping Justice for want of legal assistance"; the society agreed and directed an officer to "take such measures as shall appear proper."

found out.

H. FIRLDING, ENQUIRY, supra note 186, at 116-17 (emphasis in original). Regarding William Thomson, Recorder of London from 1714 to 1739, see E. Foss, BIoGraphis JURIDICA, supra note 16 , at 654-55.

sos Ryder Assize Diary, supra note 21, at 15.

sov CLERK of Assize, supra note 315, at 14, quoted supra text accompanying note 315.

s10 CLRO, Society for Prosecuting Felons, Forgers, \&c, Minute Book 1795 to 1800, entry for Oct. 16, 1795 (unpaginated, entries consecutive by date).

s11 Id., entry for June 19, 1795.

However difficult it is to trace the hand of counsel in eighteenth-century criminal procedure, it is harder still to learn about the work of the solicitor. We know virtually nothing about how frequently he was used, or what he did when he was employed. Because he 


\section{The implication from the society's proceedings in 1795 is that}

lacked a forensic role, he does not figure in the OBSP reports.

One peculiar source that throws a little light on the functions of solicitors is a pamphlet published in 1728 as an attack on the so-called Newgate solicitors, who were active at the Old Bailey. Directions for Prosecuting Thieves, supra note 441; see supra note 441 for discussion of Newgate solicitors. Although unsigned, the pamphlet seems to have been written by someone reasonably proximate to the Old Bailey establishment. The author dedicated it to the influential Recorder of London, William Thomson (regarding whom, see supra note 507), and the publication was advertised in the OBSP (Jan. 1728), at 8. (Mr. Daniel Ernst noticed the OBSP reference and kindly directed my attention to it.) The pamphlet is couched in the form of advice to the victim/prosecutor. It rather presupposes that the accused criminal has already been apprehended and that the victim has already been bound over by the examining JP to prosecute at trial. The author's main theme is that the services of a solicitor are not needed in preparing the case for trial. What the author explains about the work of solicitors is disclosed only for the purposes of this critique. Nevertheless, the pamphlet does allow us to see that solicitors were willing to take an active hand in the pretrial management of the criminal prosecution, including the charging decision, the drafting of the indictment, the selection and preparation of prosecution witnesses, and even pretrial examination of the accused.

There are "several very active . . . Newgate Solicitors," the pamphlet says. DrRecrions ror Prosecuting Thieves, supra note 441, at 2 (emphasis in original). The solicitor typically seeks out the victim to offer his services. "When it gets into the public Papers that such a Person was robbed of [and so forth] he is not many Hours without some of these officious Persons to advise him; and what with the Assurance of the one, and the Ignorance of the other, the Matter is undertaken on the Solicitor's Terms." Id. at 2-3. The claim is incessantly repeated that the solicitor dupes the layman into thinking that representation is necessary when it is not.

Once engaged, the solicitor takes notes on the circumstances of the offense. Id. at 3. The solicitor's "next Step is to make a great Stir in summoning all those together, who are to be Witnesses at the Trial of the Prisoner, and to direct who shall speak first, and how they shall deliver themselves to the Judge and Jury." Id. Derision aside, what the author is disclosing is that already in 1728 the solicitor was taking a hand in the pretrial examination and coaching of witnesses for trial. (The author argues, in passages quoted supra note 498, that unaided prosecution testimony is preferable. He makes a similar argument, quoted supra note 466, that the prosecutor will get better results if he has the court clerk draft the indictment without the intermediation of the solicitor.)

The pamphlet purports to reprint a bill for professional services "drawn by a Newgate Solicitor" in an unidentified case. Directions for Prosecuting ThIEves, supra note 441, at 10. Because the bill is itemized, it reveals the solicitor's involvement with a number of distinct pretrial steps. There is an entry for the initial interview and advice, another "[f]or examining and cautioning six Witnesses," and another "[f]or sending the Subpoenas," presumably to the same witnesses. Separately enumerated is a charge "[f]or attending on the Prisoner to bring him to Confession," which suggests that the prosecution solicitor thought it proper to examine the accused with a view to inducing a pretrial confession. An entry "[f]or waiting at Hicks Hall" must relate to the drafting and procuring of the indictment. Id. (emphasis in original); see also supra note 466 . And there is an entry "[f]or attending at the Old Bailey," notwithstanding the lack of forensic role. Directions por Prosecuting Theves, supra note 441, at 10 (emphasis in original).

Some clue to the axe that the author was grinding may be found in the following passage, in which he recommends the services of counsel in preference to those of a solicitor:

Indeed, when a Matter of great Consequence is to be tried, Advice is necessary; and in such Cases there is Counsel learned in the Law to apply to, who, though they are at no little Expense and Trouble in attending several Times, rather than disappoint 
the presence of defense counsel made a difference. One impulse to engage prosecuting counsel was concern about the potential effectiveness of defense counsel. Already in the Ryder years we can see that defense counsel mattered. In the eight cases in which defense counsel appeared, the accused was convicted as indicted in only one, a case of grievous misdemeanor, suborning perjury. ${ }^{512}$ Of the seven felonies, three ended in acquittals and the other four in partial verdicts.

The main responsibility of defense counsel was cross-examining the victim and the other prosecution witnesses. We can point to a couple of the cases in Ryder's notes where the job was done so skillfully that it resulted in acquittals that might not have occurred but for counsel. ${ }^{\text {s13 }}$ Until $1836^{514}$ counsel was forbidden to "address the jury," that is, to make opening and closing statements. Occasionally in the Ryder sources we see an accused misunderstand this and try to rely upon counsel when it came time for his "defense." such incident:

their Client, and neglect to do him all the Justice [that] the Merits of the Cause will admit of, yet the Charge will in the end be found less than the employing a Newgate Solicitor, who in effect does nothing at all, but what might have been as well done, and very much better, without him.

Id. at 12 (emphasis in original). The message is that counsel is better and cheaper. Having begun the pamphlet by questioning whether Newgate solicitors could fairly be called gentlemen, $i d$. at 2 , the author concludes his discussion of prosecution solicitors by questioning their honor as well as their learning. "A Solicitor, not being always acquainted with the Laws, or not caring whether they are duly executed, will often for a Fee from the Prisoner, advise the Prosecutor to compound the Felony before Sessions, or not to appear at the [trial, even though the prosecutor becomes liable thereby to criminal prosecution and to forfeiture of the bond on his recognizance to prosecute]." Id. at 14. The allegation that solicitors double-cross their prosecuting clients is made in another context a few pages earlier: "The Solicitor may be in Fee with your Prisoner to entangle you [in a defectively drafted indictment] at the same time that he takes your Money . . . ." Id. at 10.

We take from this pamphlet a lesson markedly different from that which its partisan author intended. His account allows us to see that as early as $\mathbf{1 7 2 8}$ prosecutors could obtain professional pretrial management from solicitors as well as trial representation from barristers. He further shows us that already in this period the overlap between solicitor and barrister could be a source of competition, both for business and for control of the case.

s12 Charles Wiesenthall, OBSP (Apr./May 1756, \#228), at 179.

s1s Elizabeth Woodcock, OBSP (Oct. 1754, \#479), at 310; Ryder Notebook, supra note 19, at 4-6 (directed verdict); Agnes Kirby \& Mary Hardis, OBSP (Apr./May 1756, \#\#21011), at 171; Ryder Notebook, supra note 19, at 54-56.

s14 See statute of 6 \& 7 Will. 4, ch. 114, \$§ 1-2 (1836).

s15 Beattie quotes a Surrey assize judge instructing an accused highway robber on the scope of defense counsel's license in 1752: Counsel could " speak for you in any matter of law that may arise on your trial, but cannot as to matter of fact, so you must manage your defense in the best manner you can yourself." " Beattie, supra note 166, at $334 \mathrm{n.41}$ (quoting Surrey Assize Proceedings, Mar. 1752, at 11). 
Court. Prisoner, what have you to say for yourself? . . . You hear you are charged with having divers kinds of goods in your lodgings. What account can you give how you came by them?

Prisoner. My counsel will speak for me.

Counsel. I can't speak that for you, you must speak for yourself. ${ }^{516}$

There was, nevertheless, an important sense in which counsel was able to silence the accused. By shouldering the work of crossexamination, counsel prevented the accused from making admissions in the course of attempting to cross-examine his accusers. Further, when counsel won a directed verdict by successful crossexamination, as happened in one of Ryder's cases, ${ }^{517}$ the accused could remain wholly silent. In other cases counsel limited the accused to a narrow testimonial role, after the extent of the prosecution evidence was fully known.

The decision to allow defense counsel to cross-examine prosecution witnesses brought about or facilitated a series of major structural changes in the criminal trial. There is every reason to think that these changes were unforeseen in the mid-1730s when the judges first allowed the accused to have the help of counsel in this seemingly confined sphere of the trial.

(1) Counsel made possible an effective criminal defense in which the accused took little or no part. The accused ceased to be that testimonial resource that he had always been and that he continues to be in nonadversarial procedure on the Continent. Defending no longer required testifying.

(2) Because counsel's role was limited to testing the prosecution case, he had to know what the prosecution case was. In place of the rambling altercation that had persisted into the practice of the early eighteenth century, the criminal trial underwent that ar-

s36 Alexander Murdock, OBSP (Oct. 1755, \#377), at 333, 335. For another such case see Abraham Davis et al., OBSP (Oct. 1755, \#390-92), at 349, 354:

I leave it to my counsel. Abraham Davis's defense.

Court. Your counsel can't make your whole defense, and if you have any thing to say to the fact, give an account of that now.

Prisoner. I have nothing to say farther, but that I was drawn in by this Woolf [the crown witness].

Ryder was the trial judge being referred to here as "Court." Not surprisingly, he did not find occasion to record this interlude in his own notes. Ryder Notebook, supra note 19, at $36,37$.

s17 Elizabeth Woodcock, OBSP (Oct. 1754, \#479), at 310; Ryder Notebook, supra note 19 , at 4-6. 
ticulation of sequence into prosecution and defense "cases" that so characterizes adversary procedure. In this respect the Ryder-period sources contrast strongly with those of a few decades before. Our sources show a consistently crisp division of testimony along partisan lines, inculpating evidence before exculpating. In one case, Ryder records in his notebook an occasion when he policed the line. An accomplice testified against Abraham Davis in a crown-witness prosecution for theft. "I called on Abraham Davis to ask any questions. He began by saying he would tell all and how he was drawn in, but I stopped him."

(3) When the concept of the prosecution case had been clarified for purposes of sequence, the party burdens of proof could be recognized and the motion for directed verdict at the conclusion of the prosecution case could come into play. Once this concept became familiar, it did not require counsel to raise it; we see a number of cases in the Ryder materials, both with and without defense counsel, that seem to have terminated at the end of the prosecution case. In this connection we recall the directed-verdict standard for accomplice testimony that was so firmly in place by the time Henry Fielding was protesting it in his Enquiry (1751). ${ }^{510}$ The 1787 edition of Hawkins, by Thomas Leach, previously quoted in part, ${ }^{\mathbf{5 2 0}}$ renders the rule in explicit language of sequence: "But the bare, uncorroborated testimony of an accomplice is not thought of sufficient credit to put a prisoner upon his defense; and the question therefore is, whether such testimony should be received until some fair and unpolluted evidence be previously given of the fact charged against the prisoner."

(4) Leach's remark hints at the connection between the concept of the prosecution case and the notion of the admissibility of evidence. In the hands of defense counsel, the idea of excluding evidence would have explosive potential. One of the leading nineteenth-century treatise writers on the law of evidence, looking back on the rise of his subject, thought that "the necessary consequence of [allowing defense counsel] was that objections to the admissibil349.

s18 Ryder Notebook, supra note 19, at 36, 37; see also OBSP (Oct. 1755, \#390-92), at

s1s See supra text accompanying notes 386-90.

${ }^{820}$ Supra text accompanying note 404.

s21 2 W. Hawkins, A Treatise of the Pleas of the Crown ch. 46, at 609 (T. Leach ed. 6th ed. London 1787) (emphasis in original). This passage does not appear in the previous editions of the work. 2 W. Hawkins, A Treatise of the Pleas of the Crown ch. 46, at 432 (5th ed. London 1771); 2 W. Hawkins, A Treatise of the Pleas of the Crown ch. 46, at 432 (4th ed. London 1762). 
ity of evidence were much more frequently taken, the attention of the judges was more directed to the subject of evidence, their judgments were better considered, and their decisions better remembered." grope toward the idea of exclusion. ${ }^{623}$

(5) In the decades after the Ryder period, the privilege against self-incrimination-which had been an empty slogan inherited from the time of the Tudor-Stuart jurisdictional struggles-could begin to be of consequence at common law. With counsel to assume the nontestimonial role of the accused, and with the prosecutorial burden of proof becoming clearer, the privilege to remain silent could become something more than a way to forfeit all defense.

Through to the Ryder years and for long afterwards, contemporaries had rather little sense of the main themes that we are noticing-the silencing of the accused, the growing importance of defense counsel, and the rise of the law of evidence. The adversary system developed slowly, incrementally, without plan or theory. The history of this development will have to be written mostly from later sources. Already in the Ryder period, however, we can see some of the factors that predisposed the courts to allow these early steps.

Although jurisdiction over serious crime was the exclusive province of a tiny national judiciary, crime was still only an appendage (and doubtless something of a nuisance) in a legal system otherwise geared to private law. The judges were in one sense immensely powerful, and that power is easy to see in the splendor of the assize procession, in the judges' powers of jury control, and in their command of the royal prerogative of clemency. Compared to their faceless, bureaucratic Continental counterparts, eighteenth-century English trial judges have the look of potentates.

Yet, beneath the trappings of power was one critical weakness that exposed the English judiciary to the advance of adversary procedure: The judges were ignorant of the cases they had to try. Continental judges worked from a dossier that encapsulated a thorough, official pretrial investigation into all aspects of the case. For reasons of constitutional theory and of administrative and legal history, England had failed to develop the institutions needed to

823 W. Best, A Treatise on the Principles of Evidence 133 (London 1849).

s33 See, e.g., Mary Smith, OBSP (Oct. 1755, \#389), at 340; Ryder Notebook, supra note 19 , at 41,42 , for what appears to be an objection based on relevance, which Ryder considered and rejected: "I said it might in this case be connected sufficiently." 
produce the dossier: a corps of professional magistrates well supported by a police force. English trial judges presided without any means of preparation on the merits. They relied on the JPs and the grand juries to sift out groundless cases; they expected the innocent accused to explain away mistaken cases at trial; and, as the relatively high acquittal rates suggest, they trusted themselves and the juries to resolve doubtful cases in favor of the accused.

Into the early decades of the eighteenth century the judges seem to have remained confident that this system was working well, and they must have prided themselves on the immense caseloads that they were able to discharge in a few trial days per year. Beginning, we think, in the middle third of the century, the judges became aware that there might be grievous flaws in the criminal process, although we cannot say with any precision when and why the doubts set in strongly. We have pointed to the crownwitness prosecution, where the potential for false witness was so distressing that it had led to the strict corroboration rule before 1751. The reward system, especially after the Macdaniel scandal of 1754, was another major source of doubt about the reliability of prosecution evidence in major categories of serious crime. ${ }^{524}$

The fundamental weakness of the pretrial process began to affect trial procedure. By refusing to professionalize the work of detection and investigation, the English had made themselves dependent upon crown witnesses and reward seekers. As the dangers of these devices came to be appreciated, the courts undertook to make repairs at the level of trial procedure. The courts admitted defense lawyers, initially for the sole purpose of helping the criminal accused probe prosecution evidence. And the courts began to develop rules of evidence, such as the corroboration rule and the confession rule, designed to prevent the riskiest kinds of prosecutions from going forward.

These were the adaptations that seemed readily available and that were familiar in the civil procedural system in which the judges were so steeped. Both parties had counsel in civil cases, and the pleading system served many of the functions of the law of evidence (with which, as Thayer remarked, ${ }^{525}$ it was long confused). These adaptations were meant as patches, applied for the

s24 Colquhoun complained that defense counsel exploited jurors' suspicions about the motives of prosecuting witnesses in cases in which rewards were payable, "and thus many notorious offenders often escape justice." P. Colquhoun, supra note 428, at 392-93.

s2s J.B. Thayer, A Preliminary Treatise on Evidence at the Common Lay 114-15 (1898). 
purpose of repairing the inherited system, and for many decades after Dudley Ryder's day they must have looked fairly successful. No one yet had cause to see where the path might lead. No one could have foreseen that adversary procedure harbored an inner dynamic toward complexity so relentless that it would ultimately render criminal jury trial unworkable as a routine dispositive procedure.

\section{ENDNOTES}

1. Form and citation practices. I have continued in this article certain conventions that I established in Article I for adapting the customary citation practices of this journal to the difficulties of antiquarian and manuscript sources. See Article I, supra note 1, at 263 n. $\dagger, 268$ n.18. In quotations from the OBSP, the Ryder manuscripts, and all other English and antiquarian materials, I have modernized and Americanized the spelling. Words that are abbreviated in the origirals, or rendered in part in superscript, have been written out. Obvious misprints or misspellings in the originals have been corrected without mention. Punctuation is overwhelmingly original, but it has been modernized when necessary for clarity, mainly in manuscript material where during the eighteenth century it was fairly common to omit commas and periods. Apostrophes and quotation marks occasionally have been supplied when the convention of the day was to omit them or to render the information differently. Some terminal punctuation has been either altered or supplied; in particular, when the original source uses a colon, semicolon, or dash to end a sentence, I have rendered it with a period. I have deleted the italic typeface commonly used in originals to show indirect discourse, using instead ordinary typeface and quotation marks. In rendering the titles of printed works I have left archaic orthography uncorrected, in order not to make it harder for researchers to locate works cataloged under the original spellings. I have, however, applied modern conventions of initial capitalization to titles. Where the sources employ varying spellings of a proper name, I follow where possible the usage of the Dictionary of National Biography. When citing printed sources that are exceptionally rare, I have disclosed the library and shelfmark of the exemplar that I consulted.

2. Transcribing the shorthand. The transcriber of the Ryder shorthand materials, the late K.L. Perrin, indicated in a brief memorandum to which he kindly directed my attention the principal problems posed by the system of shorthand that Ryder used. The main points are these: (a) Articles. "The two articles 
' $a$ ' and 'the' are identical in the shorthand. The transcriber has used whichever appears most probable in context ...." (b) Punctuation. "All punctuation has been inserted by the transcriber, since there is no provision for it in shorthand." (c) Number. "The plural is indicated in the shorthand by a dot over the word, and the writers often omitted to insert this." Perrin supplied the plural where he felt certain that the dot had been omitted. (d) Meanings. "A particular shorthand symbol may frequently represent different words, e.g., 'these,' 'those,' 'thus,' 'there,' 'their' [and] 'they' are identical in the shorthand." K.L. Perrin, Notes on Shorthand, bound in Sandon Hall, Harrowby MS 439 (single sheet, unpaginated, dated 1966).

Perrin did preserve the extensive underscoring of phrases and sentences that occurs in Ryder's Old Bailey notebook (but not in the assize diary). I have deleted this underscoring when quoting the source, on the ground that readers would be distracted by the incessant and relatively pointless italicization. The purpose of the underscoring, I believe, was to highlight the main facts for the extempore summing up.

3. Illustrations. Gerald Howson supplied me with the depiction of the criminal's career, reproduced on page 48, from Select Trials at the Ord Banley (London 1742).

The portrait of Macdaniel on page 111 is taken from the pamphlet by Joseph Cox cited supra note 446. The "View of the Public Office, Bow Street, with Sir John Fielding presiding," reproduced at page 74, is attributed at note 279 . Both illustrations were supplied by the photographic services department of the British Library and are reproduced here with the permission of the Trustees of the Library.

The illustration of the sanction of the pillory used at page 113 is from John Seller, A Booke of the Punishments of the Common Laws of England (London n.d. [circa 1680]); it is reproduced with permission from the copy in the collection of the Guildhall Library, City of London. (The Guildhall copy of this little work, shelfmark AN.18.3.25, may be unique. The volume contains a dozen illustrations of criminal sanctions, capital and otherwise; the captions are the only text.)

The remaining illustrations have been supplied by the Department of Prints and Drawings of the British Museum and are reproduced with the permission of the Trustees of the Museum. They are the portraits of Dudley Ryder, page 7; Thomas Gurney, page 13; Thomas de Veil, page 59; Henry Fielding, page 62; John Fielding, page 68; and Saunders Welch, page 62; as well as the Hogarth on page 79, attributed at note 301 ; and the Chelmsford assize procession of 1762 , page 116, attributed at note 462 .

A number of these illustrations have appeared elsewhere. The depiction of the criminal's career has been recently reproduced in AlBION's FATAL TreE, supra note 21, facing page 65. The portrait of Dudley Ryder was reproduced in the RxDER STUdENT DiARY, supra note 17, frontispiece. The portrait of de Veil appears in P. Pringle, Hue and Cry: The Story of Henry and John Fielding and Their Bow Street Runners (n.d.), facing page 65; the portrait of Saunders Welch appears id., facing page 129. The "View of the Public Office" and the portrait of John Fielding were reproduced in R. LesLIe-Merville, supra note 261, frontispiece and facing page 126. No contemporary portrait of Henry Fielding survives; the picture reproduced in this article is based upon a Hogarth drawing that has been widely reproduced, e.g., in 1 W. Cross, The History of Henry Findding, 
frontispiece (1918)(3 vols.); P. Rogers, HENRY FIELDing, A Biography, frontispiece (1979). 